Cornell University Law School

Scholarship@Cornell Law: A Digital Repository

Fall 2005

\title{
Why Are So Many People Challenging Board of Immigration Appeals Decisions in Federal Court? An Empirical Analysis of the Recent Surge in Petitions for Review
}

John R.B. Palmer

U.S. Court of Appeals for the Second Circuit

Stephen W. Yale-Loehr

Cornell LawSchool, SWY1@cornell.edu

Elizabeth Cronin

U.S. Court of Appeals for the Second Circuit

Follow this and additional works at: https://scholarship.law.cornell.edu/facpub

Part of the Applied Statistics Commons, Immigration Law Commons, and the Litigation Commons

\section{Recommended Citation}

Palmer, John R.B.; Yale-Loehr, Stephen W.; and Cronin, Elizabeth, "Why Are So Many People Challenging Board of Immigration Appeals Decisions in Federal Court? An Empirical Analysis of the Recent Surge in Petitions for Review" (2005). Cornell Law Faculty Publications. 1590.

https://scholarship.law.cornell.edu/facpub/1590 


\title{
ARTICLES
}

\section{WHY ARE SO MANY PEOPLE CHALLENGING BOARD OF IMMIGRATION APPEALS DECISIONS \\ IN FEDERAL COURT? AN EMPIRICAL ANALYSIS OF THE RECENT SURGE IN PETITIONS FOR REVIEW}

\author{
JoHN R.B. PALMER* \\ Stephen W. Yale-Loehr $\dagger$ \\ ElizABETH CRONIN $\ddagger$
}

I. INTRODUCTION $\ldots \ldots \ldots \ldots \ldots \ldots \ldots \ldots$

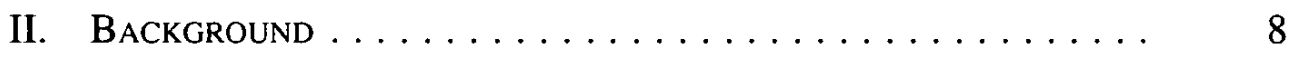

A. Substantive Standards Involved in Expulsion. . . . . . . . 10

B. Expulsion Procedures .................... 11

1. First-Instance Expulsion Decisions . . . . . . . 13

2. Administrative Review of Expulsion Orders . . . . . 17

3. Judicial Review of Expulsion Orders . . . . . . . . 19

C. Clearing the BIA's Backlog . . . . . . . . . . . 22

\footnotetext{
* Associate Supervisory Staff Attorney, U.S. Court of Appeals for the Second Circuit. The authors thank Pragati Patrick, Tom Zelenock, John Yu, and Anthony Maycock for their generous assistance with data access; Sue Siler for her efforts at the BIA library; Lisa Greenberg and Amanda Flug for all of the fun we had counting records; and Lory Rosenberg, Kathleen Moccio, Nancy Morawetz, and Nadine Wettstein for their helpful guidance and suggestions along the way. Special thanks go to Lenni Benson, Stephen Legomsky, Philip Schrag, and Charles Roth for their detailed comments on earlier drafts; and, most of all, to Mireia Artigot-Golobardes, for being willing to debate immigration law and statistics at all hours, with only minimal violence.

The views expressed herein are those of the authors and do not necessarily represent the views or policies of the Second Circuit or any other entity.

$\dagger$ Adjunct Professor, Cornell Law School; Of Counsel, True, Walsh \& Miller, LLP.

$\$$ Director of Legal Affairs, U.S. Court of Appeals for the Second Circuit.
} 
1. October 1999 "Streamlining" Regulation ....... . 23

2. March 2002 Expansion of Streamlining . . . . . . . 27

3. September 2002 "Procedural Reforms" Regulation . . 27

4. Criticism and Litigation. . . . . . . . . . . . . . 29

III. Sources And Methodology $\ldots \ldots \ldots \ldots \ldots \ldots \ldots \ldots, 32$

A. Administrative Office (AO) Data Series........... 33

B. Circuit Court Docket Information.............. 34

C. Random Sample of Second Circuit Records......... $\quad 35$

D. EOIR Freedom of Information Act Response . ....... $\quad 35$

E. Random Samples of BIA Decisions . . . . . . . . . . 36

1. Appeal Rate Information.............. 36

2. Number of BIA Decisions Arising Within Each

Circuit ................... 42

3. Composition of Pools of BIA Decisions ....... 42

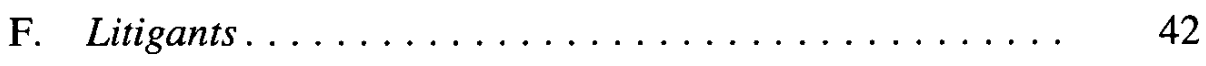

G. Limitations of the Data ................ 43

IV. Tracking the Surge. .................... 43

A. Volume of Petitions for Review. .............. 43

B. Volume of BIA Decisions ................. 48

C. Appeal Rate ........................ 51

V. EXPlaining THE INCREASEd APPEAL Rate $\ldots \ldots \ldots \ldots \ldots \ldots$

A. Composition of the Pool of BIA Decisions.......... 55

1. Outcome .................... 55

2. Error $\ldots \ldots \ldots \ldots \ldots \ldots \ldots \ldots \ldots \ldots \ldots \ldots \ldots$

3. Adjudicatory Procedure and Form of Decision ..... 59

4. Promptness of Decision............... 63

5. Substantive Issues and Expulsion Costs $\ldots \ldots \ldots \ldots \quad 68$

6. Detention ................... 73

B. BIA Characteristics................. 76 
1. Streamlining and Downsizing .......... 76

2. Volume of BIA Decisions . . . . . . . . . 76

C. Circuit Court Characteristics. . . . . . . . . . 77

1. Reversals and Settlements . . . . . . . . . . . . 77

2. Delay...................... 80

D. Shift in Behavior Among Immigration Lawyers and

Their Clients . . . . . . . . . . . . . . . . . . . . .

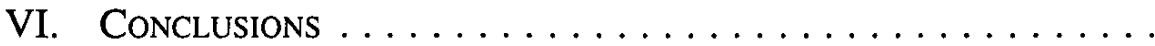

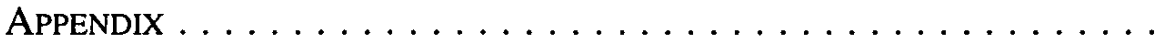

\section{INTRODUCTION}

Over the past three and a half years, the U.S. Courts of Appeals have seen a dramatic increase in immigration cases. More people than ever before are petitioning the courts to review decisions of the Board of Immigration Appeals (BIA), and these petitions now account for a substantial proportion of the caseload in the courts of appeals, especially in the Second and Ninth Circuits. This so-called "immigration surge" has placed a significant strain on judicial resources, requiring courts to hire additional staff, recruit visiting judges, and schedule extra sessions for hearing cases. It has left the Department of Justice and many immigration lawyers struggling to keep up with scheduling orders and the mountains of appellate briefs now becoming due. ${ }^{1}$

Coming on the heels of the September 11th attacks, many people initially assumed the surge in petitions for review was being driven by a government crackdown on undocumented aliens. It soon became apparent, however, that the phenomenon coincided more closely with a mostly unrelated change in the way the BIA carries out its work. The BIA, which provides administrative review over the nation's immigration courts, accumulated a lengthy backlog of cases during the 1990s. In March 2002, with the backlog at over 56,000 cases, ${ }^{2}$ the BIA began to significantly expand its use of summary procedures. It increasingly relied on single Board members in lieu of three-member

1. For a thorough discussion of the impact of the immigration surge on the U.S. Court of Appeals for the Second Circuit and its litigants, see COMM. ON THE FED. COURTS, ASS'N OF THE BAR OF THE City of N.Y., The SuRge of IMMIGRATION APPEALS and ITS IMPACT ON THE SECOND Circuit COURT OF APPEALS, available at http://www.abcny.org/pdf/report/AppealSurgeReport.pdf (Aug. 31, 2004) [hereinafter ABCNY REPORT]. On the impact felt by the Justice Department in particular, see Marcia Coyle, A Swamped DOJ Farms Out Immigration Cases, 27 NAT'L L.J. 4 (Feb. 28, 2005); Dan Eggen, Immigration Backlog Forces Justice to Shift Staffing, WASH. POST, Dec. 14, 2004, at A 11.

2. See Attorney General John Ashcroft, News Conference, Administrative Change to Board of Immigration Appeals (Feb. 6, 2002) [hereinafter Ashcroft News Conference], available at http:// www.yale.edu/lawweb/avalon/sept_11/ashcroft_011.htm. 
panels to decide cases, and it allowed these single Board members to summarily reject appeals through affirmances without opinion (AWOs) and summary dismissals. ${ }^{3}$ The volume of petitions for review reaching the federal courts began to rise almost immediately and continued to rise as the BIA implemented further procedural changes. As Second Circuit Judge Jon O. Newman described it, "It's as if a dam had built up a massive amount of water over the years, and then suddenly the sluice gates were opened up and the water poured out." 4 The result is that the courts of appeals are receiving about five times as many petitions for review today as they did before 2002.5

The immigration surge is partly accounted for by the BIA's increased output. The procedural changes and the overall pressure to reduce the backlog have caused the BIA to issue many more decisions each month, so it is reasonable to expect a proportionate increase in petitions for review reaching the federal courts. The surge, however, has been disproportionately large. Not only has the volume of BIA decisions increased, but also the rate at which they are appealed through petitions for review. ${ }^{6}$ In other words, people are now challenging a higher proportion of BIA decisions than they did before March 2002. Exactly why this is remains the object of considerable

3. See infra Part II.C. Our assertion that the March 2002 changes were mostly unrelated to the September 11 th attacks is based on the fact that these changes were largely an expansion of procedural changes that began in 1999. In congressional testimony about the regulation that codified and further expanded the March 2002 changes, the Director of the Department of Justice's Executive Office for Immigration Review stated:

[I]t has nothing to do with September 11 th. We actually started talking about these types of reforms prior to that time. And the principal catalyst for the Attorney General's interest I believe [was] when he became aware of the backlog and the time that it takes for cases to move through the Board, and saw that as a real due process problem.

See Operations of the Exec. Office for Immigration Review (EOIR), Hearing Before the H. Comm. on the Judiciary, Subcomm. on Immigration and Claims, 107th Cong. 38 (2002) [hereinafter EOIR Hearing] (statement of Kevin B. Rooney). But see Ashcroft News Conference, supra note 2 (stating that the procedural changes address the need for efficient, fair, and expeditious enforcement of immigration laws, and that these concerns "rise to a new level of importance" in the wake of the September 11 th attacks).

4. All Things Considered: Appeals Courts Flooded With Immigration Cases (NPR radio broadcast Nov. 19, 2004), available at http://www.npr.org/templates/story/story.php?storyId $=4179087$ [hereinafter All Things Considered].

5. See infra Part IV. The BIA's procedural changes and the increase in petitions for review are discussed in a detailed report by Dorsey \& Whitney LLP on behalf of the American Bar Association's Commission on Immigration Policy, Practice \& Pro Bono. Dorsey \& Whitney LLP, Board of Immigration Appeals: Procedural Reforms to Improve Case Management (2003), available at http://www.dorsey.com/files/upload/DorseyStudyABA_8mgPDF.pdf. The procedural changes themselves have also been analyzed in a number of articles. See Evelyn H. Cruz, Double the Injustice, Twice the Harm: The Impact of the Board of Immigration Appeals's Summary Affirmance Procedures, 16 StAN. L. \& PoL'Y REV. 481 (2005); Lory Diana Rosenberg, Lacking Appeal: Mandatory Affirmance by the BIA, 9 Bender's IMmigr. Bull. 91 (2004); Philip G. Schrag, The Summary Affirmance Proposal of the Board of Immigration Appeals, 12 Geo. IMmIGR. L.J. 531 (1998); Bradley J. Wyatt, Even Aliens Are Entitled to Due Process: Extending Mathews v. Eldridge Balancing to Board of Immigration Appeals Procedural Reforms, 12 WM. \& MARY BILL. RTS. J. 605 (2004).

6. We use "appeal rate" throughout this article to refer to the proportion of BIA decisions that are challenged through petitions for review. This is distinct from the measurement of the number of petitions for review filed in a given period of time, which we refer to as "volume." 
debate. $^{7}$

Many observers, including a commission of the American Bar Association, suggest that the appeal rate has increased, at least in part, because there has been a qualitative change in the BIA's decision-making. They argue that single Board members are bound to make more errors than three-member panels, especially when they are allowed to summarily affirm Immigration Judge (IJ) decisions. Moreover, they assert that regardless of any errors, single-member AWOs deny people the perception that justice has been done; people being expelled from the country will naturally appeal to the federal courts if they are left with a sense that their cases have not been meaningfully reviewed. ${ }^{8}$

In contrast, the Justice Department's Executive Office for Immigration Review (EOIR) denies that there has been any diminution in quality. It argues that people are challenging a greater proportion of BIA decisions simply to delay being expelled. According to the EOIR, whereas aliens could previously take advantage of the BIA's long backlog to gain extra time in the United States, prompt BIA decisions are driving these people to rely on petitions for review - and the courts of appeals' willingness to stay removals while adjudicating them-as a new mechanism for delay. ${ }^{9}$

In this article we use data from the federal courts, the EOIR, and the Department of Homeland Security (DHS) to help illuminate the nature and causes of the immigration surge. ${ }^{10}$ We begin with a general overview of the system of immigration adjudication in the United States, particularly the system through which the government expels people from this country (Part II). We then describe our sources and methodology (Part III) and present the

7. Within the courts of appeals, there was initially some hope that once the BIA finished clearing its backlog, its output would drop and the flow of petitions for review would dissipate. While the BIA's output will presumably drop at a certain point to match its input, this will probably cause only a small drop in petitions for review unless it is accompanied by a reduction in either input or appeal rate. For instance, the courts of appeals received 10,804 petitions for review during fiscal year 2004 , which represented about $23 \%$ of the 46,503 BIA decisions issued during that same period in appeals from IJ proceedings. If the BIA decided only as many cases as it received from IJ proceedings in fiscal year 2004, which was 40,100 , the $23 \%$ appeal rate would have resulted in 9223 petitions for review-still a huge increase from the 1700 or so petitions received during fiscal years 2000 and 2001. If the BIA had decided only as many cases as it received from IJ proceedings during fiscal year 2001 , which was 24,803 , the $23 \%$ appeal rate would have resulted in 5705 petitions for reviewagain, still a huge increase. (These figures are calculated from the data contained in EOIR, OFFICE OF Planning and Analysis, Fy 2004 Statistical Year Book S2 (Mar. 2005) [hereinafter EOIR YB 2004], available at http://www.usdoj.gov/eoir/statspub/fy04syb.pdf, and from the AO data series discussed below in Part llI.A).

8. See aba Comm'n on Immigration Policy, Practice \& Pro Bono, Seeking Meaningful REVIEW: FINDINGS AND RECOMMENDATIONS IN RESPONSE TO DORSEY \& WHITNEY STUDY OF BOARD OF immigration APPEals Procedural ReForms (2003), http://www.abanet.org/immigration/bia.pdf [hereinafter ABA REPORT]; DORSEY \& WhITNEY LLP, supra note 5.

9. See EOIR, Fact Sheet: BIA Streamlining 2 (Sept. 15, 2004), http://www.usdoj.gov/eoir/press/ 04/BIAStreamlining2004.pdf [hereinafter EOIR Streamlining Fact Sheet].

10. We focus solely on the surge in petitions for review, and not on other challenges to BIA decisions, such as those brought through habeas corpus petitions. In addition, we examine only petitions for review filed before enactment of the REAL ID Act, Pub. L. No. 109-13, Div. B., 119 Stat. 231 (2005). 
detailed picture of case flow that emerges from our data (Part IV). This picture confirms that there has been an increase in both the volume of BIA decisions and the proportion that are appealed. Finally, we propose a series of variables that might help to explain the observed increase in appeal rate, and we use our data to explore the importance of each of these variables (Part V).

We started this research with the (naive) hope that we would uncover a clear-cut explanation for the increased appeal rate. We assumed that AWOs and single-member decisions are being appealed and reversed at significantly higher rates than other decisions that leave aliens with final orders of removal. We were initially skeptical of the EOIR's theory because we did not understand why someone who seeks delay in the courts of appeals would not seek delay, regardless of how promptly the BIA reaches its decisions. However, we assumed that if the theory were correct, we would find that the people filing petitions for review tended to be the ones who had achieved the least amount of administrative delay.

In our defense, we are lawyers. The linear world of legal reasoning makes it easy to forget the complexity of real life social phenomena. After a year of collecting and analyzing gigabytes worth of data, we realize that the explanation for the immigration surge is at once far more complicated and far simpler than we imagined. We did not detect a higher appeal rate in the latter half of 2004 for either summary decisions or prompt decisions, but we cannot rule out the possibility that such a higher rate existed in the past, or that either of those variables are potential causes of the surge. We identified a number of other variables that may have contributed to the surge, including BIA errors, substantive issues on which BIA decisions hinge, aliens' "expulsion costs," and the amount of delay that can be achieved in the courts of appeals. However, we are unable to confirm or discard any of these variables.

At the same time, a few variables have begun to crystallize into a hypothesis that we find quite persuasive and, in many ways, simpler than the assumptions with which we started. The hypothesis focuses on a surge in BIA decisions that leave non-detained aliens with final expulsion orders and a fundamental shift in behavior on the part of immigration lawyers and their clients. We think this shift was triggered by the high volume of BIA decisions issued starting in March 2002, and a general dissatisfaction with the BIA's review.

First, we already knew that the overall volume of BIA decisions increased in 2002 and that this accounts for part, but not all, of the increase in petitions for review. More important than overall volume, however, is the volume of

11. We define "expulsion cost" as the range of losses, deprivations, and suffering that a person incurs by being expelled. It includes the loss of any investments the person made in coming to the United States and the difficulty he or she would have in returning. It is therefore similar to the "investment hypothesis" discussed in Peter H. Schuck \& Theodore Hsien Wang, Continuity and Change: Patterns of Immigration Litigation in the Courts, 1979-1990, 45 STAN. L. REv. 115, 134-35 (1992). 
decisions that leave people with final expulsion orders. There is evidence that the BIA began denying a larger proportion of aliens' appeals in 2002, and that the volume of final expulsion orders has therefore increased even more sharply than overall volume. ${ }^{12}$ Because final expulsion orders are the only decisions that can be challenged through petitions for review, the overall appeal rate (measured using all BIA decisions as the denominator) increased more than it would have if the proportion of final expulsion orders had remained the same.

Second, the increase in final expulsion orders has been felt mainly by aliens who are not in detention. Since detained aliens are often obstructed from filing petitions for review by such factors as lack of access to counsel and by the jurisdictional bars triggered by certain criminal convictions, ${ }^{13}$ the increase in the proportion of BIA decisions involving non-detained aliens has probably caused a further increase in appeal rate. These first two variablesproportion of final expulsion orders and proportion of non-detained aliensinvolve no change in behavior on the part of the litigants, but simply a change in the composition of the pool of BIA decisions that we use to measure the appeal rate. ${ }^{14}$

Finally, the appeal rate may have increased even further due to a change in behavior among immigration lawyers and their clients. Until 2002, many of the immigration lawyers who represented clients in expulsion proceedings had practiced almost exclusively at the administrative level. There were probably a number of reasons for this, including fear of unfavorable circuit precedent and the difficulty of entering an unfamiliar forum when lowpaying clients necessitate economies of scale. Starting in March 2002, however, these lawyers were suddenly faced with a huge number of BIA decisions that not only rejected a greater proportion of their clients' claims, but did so in a way that undermined their confidence in the BIA and gave them colorable (if ultimately unsuccessful) facial challenges to the BIA's procedures. As a result, many immigration lawyers moved significant portions of their practices into the federal courts for the first time. Having done so, they are now comfortable in this forum. They are less afraid of adverse precedent, and a steady stream of final orders of removal from the BIA means that economies of scale can be utilized just as easily here as at the administrative level. Moreover, they are still deeply dissatisfied with the review they are receiving from the BIA, and they have discovered a host of issues to litigate, even now that their facial procedural challenges have been rejected. ${ }^{15}$

12. See infra notes $\mathbf{2 4 6}-248$ and accompanying text.

13. As noted above in note 10, we have focused only on petitions for review filed before enactment of the REAL ID Act. We have not examined habeas corpus petitions, which are often used to sidestep jurisdictional bars.

14. See infra Part V.A.1.

15. See infra Part V.D. 
We offer this hypothesis as a starting point only because there is still a large amount that we do not know. Our gigabytes of data constitute just a small fraction of what would be needed to make any confident assertions about the causes of the immigration surge, so our research has been more exploratory than confirmatory. We hope, however, that this article provides some insight into the causes of the immigration surge and the dynamics of immigration litigation generally, and that it will contribute to the small but growing body of empirical work in this area. ${ }^{16}$

\section{BACKGROUND}

Our starting point is the observation that the number of immigration cases filed in the courts of appeals each month has increased. Specifically, there has been a well-documented increase in petitions for review of final orders of removal-final administrative orders directing the expulsion of particular people from U.S. territory. ${ }^{17}$ These petitions for review constitute just one process in the much larger system of immigration law, which regulates the admission and expulsion of aliens. ${ }^{18}$ Before we can approach the question of

16. The seminal work on the dynamics of immigration litigation in the federal courts is the 1992 study by Peter Schuck and Theodore Wang, supra note 11, who noted the absence of research in this area at the time they were writing. The most important recent studies have been those by Dorsey \& Whitney LLP, supra note 5, and the Association of the Bar of the City of New York, supra note 1.

17. See ABCNY REPORT, supra note 1; ABA REPORT, supra note 8; DORSEY \& WHITNEY LLP, supra note 5; Richard Acello, Asylum Logjam: Streamlined Immigration Cases Are Flooding Federal Appeals Courts, 91-OCt A.B.A. J: 18 (Oct. 2005); Pamela A. Maclean, Circuit Court Review: Judges Blast Immigration Rulings, 28 NAT'L L.J. S1 (Oct. 24, 2005); BIA Appeals Remain High in 2 nd and 9th Circuits, 37 The THIRD BRANCH 2 (Administrative Office of the U.S. Courts Office of Public Affairs, Washington, DC), Feb. 2005, available at http://www.uscourts.gov/ttb/feb05ttb/bia/ index.html; Tom Brune, Immigration in the Courts, N.Y. NEwSDAY, Dec. 15, 2004, at A7; Claire Cooper \& Emily Bazar, Immigration Appeals Swamp Federal Courts, SaCramento BeE, Sept. 5, 2004, at A1; Coyle, supra note 1; Eggen, supra note 1; Immigration Appeals Surge in Courts, 35 THE ThIRD BRANCH 9 (Administrative Office of the U.S. Courts Office of Public Affairs, Washington, DC), Sept. 2003, available at http://www.uscourts.gov/ttb/sep03ttb/immigration/index.html; Stanley Mailman \& Stephen Yale-Loehr, Immigration Appeals Overwhelm Federal Courts, 231 N.Y. L.J. 1, 3 (Dec. 27, 2004); Solomon Moore \& Ann M. Simmons, Immigrant Pleas Crushing Federal Appellate Courts: As Caseloads Skyrocket, Judges Blame the Work Done by the Board of Immigration Appeals, L.A. Times, May 2, 2005, at 1; Tom Perrotta, Immigration Appeals Surge in Second Circuit, 231 N.Y. L.J. 1 (Nov. 4, 2004); Nahal Toosi, Asylum-Seekers Find Legal Haven in Chicago-Based Appeals Court: Prominent Federal Judge Has Lent Support to Those Fearing Persecution if Deported, Mil.waukee J. Sentinel, July 31, 2005, at B 1; All Things Considered, supra note 4; Lou Dobbs Tonight: Pope Benedict XVI Grasps Keys of St. Peters; Ag Jobs Bill Setback; I.5 Million Credit Card Nos. Stolen from DSW (CNN television broadcast Apr. 19, 2005) (including short interviews with Chief Judges Mary Schroeder and John Walker, and Professor Stephen Legomsky), transcript available at http://transcripts.cnn.com/TRANSCRIPTS/0504/19/ldt.01.html.

18. "Alien" is the term of art used in the Immigration and Nationality Act to describe people who are neither citizens nor nationals of the United States. See 8 U.S.C. $\$ 1101$ (a)(3) (2000). We use it interchangeably with "noncitizen," which is slightly less precise (since it ignores the small group of noncitizen nationals-mainly natives of American Samoa and Swains Island-who are neither citizens nor aliens) but also less prone to conjure up images of invasions from outer space. See, e.g., Gerald L. Neuman, Aliens as Outlaws: Government Services, Proposition 187, and the Structure of Equal Protection Doctrine, 42 UCLA L. Rev. 1425, 1428 (1995).

On the definition of immigration law, as well as the related body of alienage law, which governs aliens' rights and obligations, see Stephen $\mathbf{H}$. Legomsky, Immigration Law and the Principle of Plenary Congressional Power, 1984 SuP. CT. Rev. 255, 256 (1984); Hiroshi Motomura, Whose 
why people are filing more petitions for review, we must understand something about this larger legal system.

To both adequately and concisely describe United States immigration law is not an easy task. The field is governed primarily by the Immigration and Nationality Act (INA) and its many amendments, which taken together form one of the most complicated statutes in existence. ${ }^{19}$ The INA is administered by a myriad of federal agencies including the Departments of Justice, State, Labor, and Health and Human Services, as well as the newly created Department of Homeland Security. Moreover, the system is in constant flux. In addition to ever-changing patterns of human migration, there are frequent amendments to the INA and to administrative rules and practices, and regular pronouncements by the courts. As this article was in its final stages, for instance, Congress passed the REAL ID Act, which, among other things, significantly alters the jurisdictional terrain that people must navigate when challenging BIA decisions. ${ }^{20}$ This comes just a few years after a major administrative reorganization, whereby Congress disbanded the Justice Department's Immigration and Naturalization Service (INS)-long the agency primarily responsible for administering and enforcing the INA-and transferred its functions to three entities within the Department of Homeland Security (DHS). ${ }^{21}$ To get a handle on immigration law, it is not enough to simply examine a snapshot of the system as it exists at present; we must also look at how it has evolved over time.

To simplify things, we will begin in 1971 (the first year for which we have data on petitions for review) and focus mostly on the area of immigration law that deals with how the government expels noncitizens. We use "expulsion"

Immigration Law?: Citizens, Aliens, and the Constitution, 97 Colum. L. Rev. 1567, 1598-99 (1997); Hiroshi Motomura, Immigration and Alienage, Federalism and Proposition 187, 35 VA. J. INT'L L. 201, 202-03 (1994); Hiroshi Motomura, Immigration Law After a Century of Plenary Power: Phantom Constitutional Norms and Statutory Interpretation, 100 YALE L.J. 545, 547 \& n.5 (1990); Michael Scaperlanda, Partial Membership: Aliens and the Constitutional Community, 81 Iowa L. REv. 707, 713 (1996). See also Linda S. Bosniak, Membership, Equality, and the Difference that Alienage Makes, 69 N.Y.U. L. REv. 1047 (1994) (discussing the tension inherent in the law's treatment of aliens "inside" immigration law versus "outside" immigration law).

19. See, e.g., Lok v. INS, 548 F.2d 37, 38 (2d Cir. 1977) (describing the INA as an example of "Congress's ingenuity in passing statutes certain to accelerate the aging process of judges"); Yuen Sang Low v. Att'y Gen., 479 F.2d 820, 821 (9th Cir. 1973) ("[W]e are in the never-never land of the Immigration and Nationality Act, where plain words do not always mean what they say"); STEPHEN H. Legomsky, Immigration and Refugee Law and Policy l (4th ed. 2005) (describing the INA as a "hideous creature," its hundreds of pages containing "excruciating technical provisions that are often hopelessly intertwined"); Charles Gordon, The Need to Modernize Our Immigration Laws, 13 SAN DIEGO L. REV. 1, 2 (1975) (describing the INA as "cumbersome, obscure, and out of harmony with current conceptions"); Harry N. Rosenfield, Necessary Administrative Reforms in the Immigration and Nationality Act of 1952, 27 FORDHAM L. Rev. 145, 145 \& n.2 (1958) (suggesting that "few laws enacted by the Congress are longer and more complex" than the INA).

20. See REAL ID Act, supra note 10.

21. See Homeland Security Act, Pub. L. No. 107-296, 116 Stat. 2135 (2002), amended by Pub. L. No. 108-7, § 105, 117 Stat. 11, 531 (2003); see generally Thomas AleXANder AleiniKofF, David A Martin \& Hiroshi Motomura, Immigration and Citizenship: Process and Policy 238-46 (5th ed. 2003). 
to refer to what used to be known as either "exclusion" or "deportation," depending on the alien's circumstances, and is now known by the more general (if somewhat antiseptic) term "removal." The process of expulsion is what generates petitions for review, as such petitions can be filed only from final expulsion orders. Although the dynamics of the recent surge in petitions for review may also be affected by external forces, it is ultimately through the expulsion process that such effects are felt.

\section{A. Substantive Standards Involved in Expulsion}

We begin with a general overview of the substantive standards used to decide who may be expelled from the United States. These standards fall into four broad groups: (1) admissions categories; (2) inadmissibility/excludability grounds; (3) deportability grounds; and (4) relief.

The admissions categories are the initial criteria for determining who will be allowed into the country and under what conditions. In order to come into and remain in the United States legally, a noncitizen must generally fit within one of these categories. For instance, someone may be admitted temporarily as a tourist ${ }^{22}$ or permanently as the spouse of a U.S. citizen. ${ }^{23}$ Of course, the admissions categories account for only a portion of the noncitizens who actually enter the United States. A large number enter illegally, by either evading immigration officials or by presenting false documents. ${ }^{24}$

Even if the person fits into an admissions category, he or she may nonetheless be expelled under one of the grounds of inadmissibility/ excludability or deportability. These grounds are based on conduct or status that Congress has deemed undesirable. ${ }^{25}$ For instance, an alien may be inadmissible if he or she has a communicable disease ${ }^{26}$ or deportable if he or she has been convicted of an aggravated felony. ${ }^{27}$ The differences between inadmissibility, excludability, and deportability hinge on a change in law that took effect in 1997. Before 1997, what are now known as inadmissibility grounds were referred to as excludability grounds. They applied to aliens who had not yet entered the United States, whereas the deportability grounds applied to those who had. ${ }^{28}$ Entry was a term of art surrounded by a substantial body of case law, but it generally entailed either being inspected

\footnotetext{
22. See INA § 101(a)(15)(B), 8 U.S.C. § 1101(a)(15)(B) (2000).

23. See INA $\$ 201(\mathrm{~b})(2)(\mathrm{A})(\mathrm{i}), 8$ U.S.C. $\$ 1151(\mathrm{~b})(2)(\mathrm{A})(\mathrm{i})(2000)$.

24. For a number of fascinating essays on the growing practice of smuggling humans across borders, see Global Human Smuggling: Comparative Perspectives (David Kyle \& Rey Koslowski eds., 2001). On the experiences of people smuggled to New York from China's Fujian Province, see Ko-Lin Chin, Smuggled Chinese: Clandestine Immigration to the United States (1999); Peter KWONG, ForbidDEN WORKERS: ILLEGAL CHINESE IMMIGRANTS AND AMERICAN LABOR (1997).

25. See ALEINIKOFF ET AL., supra note 21 , at $427,550$.

26. See INA $\S 212(\mathrm{a})(1)(A)(\mathrm{i}), 8$ U.S.C. $\S 1182(\mathrm{a})(1)(\mathrm{A})(\mathrm{i})(2000)$.

27. See INA $\S 237(a)(2)(A)(i i i), 8$ U.S.C. $\$ 1227$ (a)(2)(A)(iii) (2000).

28. See Aleinikoff et al., supra note 21, at 427-28; Stephen H. Legomsky, ImMigration and Refugee Law And Policy 496 (4th ed. 2005).
} 
and admitted at a border or port of entry, or illegally sneaking into the United States without inspection. ${ }^{29}$ In 1997, Congress shifted the critical line from entry to admission, ${ }^{30}$ which requires that the alien enter lawfully, after being inspected and authorized by an immigration officer. ${ }^{31}$ The excludability grounds were modified and renamed "inadmissibility grounds," and they were made applicable to aliens who had not yet been admitted to the United States (even if they had entered and are physically present). The deportability grounds now apply to those who have been admitted. ${ }^{32}$

The final group of standards that must be considered are those governing relief from expulsion. An inadmissible (or excludable) or deportable alien may avoid being expelled by proving eligibility for certain forms of relief. An alien may obtain relief, for instance, by showing that expulsion would result in exceptional and extremely unusual hardship to family members in the United States ${ }^{33}$ or by showing a likelihood of persecution in his or her country of origin. ${ }^{34}$

Looking at the expulsion system from the perspective of case flow (which is not to minimize all of the human drama that lies behind the numbers, but simply to aid us in understanding the surge in petitions for review), the admissions categories, combined with the means for illegal entry, affect the size and composition of the pool of noncitizens against which the government might choose to initiate expulsion proceedings. The inadmissibility, excludability, and deportability grounds affect the flow of cases from this pool into the expulsion system. The grounds for relief, as well as such things as prosecutorial discretion, ${ }^{35}$ act as release valves through which cases may exit. Some of these grounds, such as the mass legalization program enacted in 1986, have had massive, if temporary, impacts on reducing the number of cases in the system. ${ }^{36}$

\section{B. Expulsion Procedures}

While the substantive standards have important consequences for the flow of cases through the system, the procedures actually direct this flow. They control when, where, and how substantive issues may be raised, making it virtually impossible for certain cases to reach the federal dockets at all, while

29. See Brian K. Bates, A Brief Tour of Wonderland: A Practical Introduction to Exclusion Proceedings, IMMIGR. BRIEFINGS, Jan. 1990, at 6-7; LEGOMSKY, supra note 28, at 504-25.

30. See Illegal Immigration Reform and Immigrant Responsibility Act (IIRIRA) of 1996, Pub. L. No. 104-208, $\S \$ 301-302$ (effective Apr. 1, 1997) [hereinafter IIRIRA].

31. See INA § 101(a)(13), 8 U.S.C. $\$ 1101$ (a)(13) (2000).

32. See generally ALEINIKOFF ET AL., supra note 21, at 428; LEGOMSKY, supra note 28, at 496; Charles Gordon, Stanley Mailman \& STEPhen Yale-Loehr, Immigration Law and Procedure

\$ $63.01[2]-[3]$ (rev. ed. 2005) [hereinafter ILP].

33. See INA § $240 A(b), 8$ U.S.C. § 1229(b) (2005).

34. See INA \$ 208,8 U.S.C. $\$ 1158$ (2005).

35. We discuss prosecutorial discretion further in note 37.

36. See infra note 218 and accompanying text. 
ensuring that others will reach these dockets on a regular basis.

The process by which the government expels someone from the United States can be broken down into three basic stages: identifying the person as potentially subject to expulsion, deciding to expel the person, and ensuring that the person actually leaves the country. At each step along the way, the government may exercise prosecutorial discretion not to proceed further, thereby allowing the person to remain in the country, at least temporarily. ${ }^{37}$ Depending on the circumstances, the person being expelled may also have an opportunity to end the process at certain points along the way by agreeing to depart voluntarily. ${ }^{38}$ The incentive to do this is great for some people because it may allow them to avoid the collateral repercussions of an expulsion order, which include a period of inadmissibility and the possibility of criminal prosecution if the person re-enters without permission. ${ }^{39}$

The first and third stages of expulsion (identification of aliens and enforcement of expulsion decisions) were primarily the responsibility of the INS until March 2003, and are now the responsibility of its successor, DHS. Aliens may be identified by DHS as potentially subject to expulsion when they seek admission at ports of entry or apply for immigration benefits; or, they may be identified as a result of DHS investigations. ${ }^{40}$ At the end of the process, once a final expulsion order has been entered and any stays lifted, DHS Detention and Removal staff are tasked with enforcing the order, often arranging for transportation and physically placing people on buses .or

37. The general principles for prosecutorial discretion in the expulsion context are laid out in a Nov. 17, 2000, memorandum from then INS Commissioner Doris Meissner, available at http:// uscis.gov/graphics/lawsregs/handbook/discretion.pdf. See Meissner Issues Prosecutorial Discretion Guidance on Her Last Day as INS Commissioner, 77 INTER PRETER Releases 1661 (2000); AleinIKOFF ET AL., supra note 21, at 616-19. On the use of prosecutorial discretion at particular stages of the process, see Designating Aliens for Expedited Removal, 69 Fed. Reg. 48,877, 48,878-79 (Dep't of Homeland Sec., Aug. 11, 2004) (stating that DHS intends to exercise prosecutorial discretion in applying expedited removal procedures); Asylum Procedures, 65 Fed. Reg. 76, 121, 76,122 (Dep't of Justice, Dec. 6, 2000) (supplementary information) (discussing use of prosecutorial discretion to allow asylum claims by people found subject to expedited removal on national security grounds under INA \$ 235(c)); ALEINIKOFF ET AL., supra note 21, at 617-19 (discussing "deferred action status" and reprinting the relevant portion of the INS's Standard Operating Procedures).

38. See INA $\S 240 \mathrm{~B}, 8$ U.S.C. $\S 1229 \mathrm{c}$ (2000) (giving the Attorney General authority to grant voluntary departure under certain conditions); 8 U.S.C. $\$ 235(a)(4)(2000)$ (giving the Attorney General authority to allow aliens to withdraw their applications for admission and depart voluntarily); 8 C.F.R. $\S \S 240.25,100.2$ (2005) (delegating the Attorney General's authority to the former INS); Homeland Security Act of 2002, Pub. L. No. 107-296, $\$$ 441, 1512(d), 1517, 116 Stat. 2135 , (transferring functions from the INS to DHS and making statutory and regulatory references to INS applicable instead to DHS); 8 C.F.R. $\$ \S 1.1(\mathrm{c})$, (d), (o) (2005) (making INS references in 8 C.F.R. applicable to DHS). See also EOIR, Forms of Relief From Removal (Aug. 3, 2004) (stating that DHS has authority to grant voluntary departure), http://www.usdoj.gov/eoir/press/04/ReliefFromRemoval. pdf.

39. See ALEINIKOFF ET AL., supra note 21 , at 581-82, 609-11. The incentive may be especially great for arriving aliens, who very frequently choose to withdraw their applications for admission rather than face expulsion proceedings. See UNITED STATES COMMISSION ON INT'L Religious Freedom, 1 Report on Asylum Seekers in ExPEdited Removal 32 (2005) [hereinafter USCIRF] (reporting that of 177,040 aliens subject to expedited removal in fiscal year 2003, 128,328 withdrew their applications for admission and departed voluntarily); Bates, supra note 29, at 17.

40. See AleINIKOFF ET AL., supra note 21, at 240-41; LEGOMSKY, supra note 28, at 634-35. 
airplanes. $^{41}$

The second stage of the expulsion process requires closer attention. The decision to expel someone can be made in a number of different ways, depending on the circumstances. Currently, DHS, the Department of Justice and the federal courts are all involved. Before March 2003 the decision process included only the Department of Justice and the federal courts. To explain the variation in the procedures used to make the decision to expel someone, it is useful to further divide the process into (1) the first-instance decision, (2) administrative review (if any), and (3) judicial review (if any). For each of these sub-stages, the variation falls along a spectrum from more to less process; from adversarial hearings before neutral decision-makers to summary decisions by low-level executive officers; from full administrative and judicial review to none at all.

\section{First-Instance Expulsion Decisions}

The standard procedure for reaching a decision, in the first-instance, to expel someone involves adversarial hearings before an administrative adjudicator. $^{42}$ In addition to this standard procedure, there are a number of specialized procedures-all involving summary or expedited decisionmaking - that may be used in certain classes of cases. In 1971, almost all first-instance decisions were made using the standard procedure, and specialized procedures were used for only a few small classes. Over the years, however, Congress has created new, specialized procedures and expanded the classes to which they apply. Probably the most important of these new procedures is referred to as expedited removal. It took effect in 1997 and applies mainly to arriving aliens who lack proper documentation. Today, expedited removal and a number of other specialized procedures are used in a substantial proportion of expulsion cases. ${ }^{43}$

\section{a. Standard expulsion procedures}

The standard procedure of adversarial hearings is initiated by DHS, which acts in a prosecutorial role. After identifying the person it seeks to expel, DHS must serve that person with a charging document, directing him or her to appear before an IJ at a designated time and place. ${ }^{44}$ The IJ then conducts

41. See AlEINIKOFF ET AL., supra note 21, at 241.

42. The adversarial nature of the hearings is relaxed to some degree when adjudicating claims for persecution-based relief. See Yang v. McElroy, 277 F.3d 158, 162-63 (2d Cir. 2002); Jacinto v. INS, 208 F.3d 725, 732-33 (9th Cir. 2000); Matter of S-M-J-, 21 I. \& N. Dec. 722, 726-30 (BIA 1997); ILP, supra note 32 , at $\$ 34.02[9][\mathrm{d}]$.

43. See USCIRF, supra note 39 , at 32 (reporting, for instance, that 177,040 aliens were subject to expedited removal procedures in fiscal year 2003 (including those who withdrew their applications for admission before being ordered removed)).

44. The DHS District Director bringing the proceedings has discretion to commence them in any of the Immigration Courts throughout the United States. See 8 C.F.R. $\S \S 1003.14(a), 1003.20$ (a) 
hearings to determine whether or not the person should be expelled. DHS is represented at the hearings by a trial attorney who has the burden of proving that the person is an alien. ${ }^{45}$ If DHS succeeds in meeting this burden, then the alien (who has the right to be represented by counsel) must prove either that he or she has already been admitted to the United States or that he or she is entitled to be admitted. If the alien proves the former, then the government has the burden of proving that he or she falls within one of the grounds of deportability discussed above. Finally, if it is established that the alien is either inadmissible or deportable, the alien may seek relief from being expelled, and his or her eligibility for such relief, as well as any discretionary elements, must then be adjudicated.

At the end of this process, the IJ makes a decision. If the IJ determines that the person is inadmissible or deportable and denies all relief that would allow the person to remain within the United States, then the judge must either order the person removed to a particular country or grant the person voluntary departure. ${ }^{46}$ If the IJ grants voluntary departure, the judge must also enter an alternate removal order that automatically takes effect if the terms of the voluntary departure are violated. ${ }^{47}$

The basic contours of this procedure have existed since long before 1971, but they have changed somewhat over the years. As already noted, the functions currently carried out by DHS were carried out by the INS before 2003 , so it was INS trial attorneys who appeared and argued the government's case at expulsion hearings. More importantly, the decision-makers of 1971 were not the IJs we know today, but rather INS special inquiry officers. ${ }^{48}$ These officers were in a somewhat peculiar position: on the one hand, they conducted an adjudicatory process, presiding over adversarial hearings at which INS trial attorneys lodged charges in favor of expulsion; on the other hand, the special inquiry officers themselves worked for the INS. As a result there existed in 1971 a tension between the officers' adjudicatory role and the enforcement pressures generated within the INS. This tension had long been recognized, ${ }^{49}$ and various attempts to remedy it have resulted in changes to the organization and attributes of the administrative adjudicators.

Steps had already been taken before 1971 to make the special inquiry

(2005); Matter of Seren, 15 I. \& N. Dec. 590, 591 (BIA 1976). The IJ, however, may grant a change of venue for good cause, based on such factors as administrative convenience, expeditious treatment of the case, location of witnesses, and cost of transporting witnesses or evidence. See 8 C.F.R. $\S 1003.20$ (b) (2005); Matter of Rahman, 20 I. \& N. Dec. 480, 482-83 (BIA 1992). In practice, it appears that aliens are often charged in an Immigration Court near their port of entry, and then change venue to a court near where they intend to reside.

45. See 8 C.F.R. $\$ 1240.8(\mathrm{c})(2005)$.

46. See 8 C.F.R. \$ $1240.12(2005)$.

47. See 8 C.F.R. \$ 1240.26(c), (d) (2005); ALEINIKOFF ET AL., supra note 21, at 610-11.

48. See Sidney B. Rawitz, From Wong Yang Sung to Black Robes, 65 InTER PRETER ReLEASEs 453, 457 \& n. 16 (1988).

49. See, e.g., Wong Yang Sung v. McGrath, 339 U.S. 33 (1950); Rawitz, supra note 48, at 457; ALEINIKOFF ET AL., supra note 21, at 249. 
officers both more professional and more independent. ${ }^{50}$ In 1973 they were authorized to use the title Immigration Judge and to wear judges' robes. ${ }^{51}$ In 1983 they were moved out of the INS altogether, and placed within the newly-created EOIR. Although the EOIR was still part of the Department of Justice, the move meant that IJs were no longer dependant on the INS for their budget and administrative services. ${ }^{52}$ Finally, IJs have been further insulated since March 2003 because the EOIR remains part of the Department of Justice, while the INS' functions have been transferred to DHS. ${ }^{53}$ Of course, this latest arrangement still leaves the EOIR within a Cabinet department heavily involved in law enforcement, so concerns over IJ independence remain an issue. ${ }^{54}$

\section{b. Specialized procedures}

In addition to the standard expulsion procedures, specialized procedures may be used in certain circumstances. The INA, as first enacted, provided for expulsion decisions without hearings for arriving alien crewmen and stowaways, and, in section 235(c), for arriving aliens who were deemed to fall within the political ideology or national security grounds of inadmissibility. ${ }^{55}$ Such provisions still exist today, ${ }^{56}$ except that political ideology was removed from the section 235(c) procedure in $1990,{ }^{57}$ and all of the grounds have been tempered somewhat by the possibility of persecution-based relief. $^{58}$

In the 1980s Congress began to create specialized expulsion procedures for people convicted of certain crimes. At first, these entailed simply ensuring

50. See Rawitz, supra note 48, at 457-59; ALEINIKOFF ET AL., supra note 21, at 249-50.

51. See Rawitz, supra note 48, at 457-59, 458 \& n.24; ALEINIKOFF ET AL., supra note 21 , at 249-50. This authorization, however, was only by regulation. They continued to be referred to as special inquiry officers in the statute until 1996. See ALEINIKOFF ET AL., supra note 21, at 250.

52. See Rawitz, supra note 48, at 458-59; ALEINIKOFF ET AL., supra note 21, at 250.

53. See Aleinikoff ET AL., supra note 21, at 251.

54. See David A. Martin, Immigration Policy and the Homeland Security Act Reorganization: An Early Agenda for Practical Improvements, 80 INTER PRETER RELEASES 601, 616 (2003); ALEINIKOFF ET AL., supra note 21 , at 251 . Indeed, many argue that the EOIR ultimately should be removed from the Department of Justice altogether, and reconstituted in some form as an independent adjudicative body. See, e.g., Marshall Fitz, Symposium Remarks: Changing the Face of Immigration: A Year in Transition, ST. JoHn's J. LeGAL COMMENT. 33, 38 (2004); Stephen H. Legomsky, Deportation and the War on Independence, 91 CoRnell L. Rev. (forthcoming 2006) (draft on file with authors); Peter J. Levinson, A Specialized Court for Immigration Hearings and Appeals, 56 Notre Dame LAW. 644 (1981); Martin, supra note 54, at 616; James J. Orlow, Comments on "A Specialized Statutory Immigration Court," 18 San Diego L. Rev. 47, 50-51 (1980); Maurice A. Roberts, Proposed: A Specialized Statutory Immigration Court, 18 SAN DIEGO L. REv. 1 (1980); Leon Wildes, The Need for a Specialized Immigration Court: A Practical Response, 18 SAN DIEGo L. REV. 53, 62 (1980); National Association of Immigration Law Judges, An Independent Immigration Court: An Idea Whose Time Has Come (Jan. 2002), http://www.woodrow.org/teachers/esi/2002/CivilLiberties/Projects/ PositionPaperImmigrationJudges.pdf.

55. See INA, Pub. L. No. 82-414, §§ 235(c), 251, 252, 273, 66 Stat. 163, 199-00, 219-21, 227-28

(1952); Jack Wasserman, Immigration Law and Practice 42 I-23 (3d. ed. 1979).

56. See INA $\S \S 235(\mathrm{a})(2)-(\mathrm{c}), 252,8$ U.S.C. $\S \S 1225(\mathrm{a})(2)-(\mathrm{c}), 1282(2000)$.

57. See Immigration Act of 1990, § 603(a)(11), 8 U.S.C $\$ 1225$ (1990).

58. See ILP, supra note $32, \S 34.02[15]$. 
that hearings take place as "expeditiously as possible after the date of the conviction." 59 This led to the establishment of the Institutional Hearing Program, which entails holding expulsion hearings in designated state and federal prisons. ${ }^{60}$ In 1994, however, Congress directed the Attorney General to create abbreviated procedures for expelling non-permanent resident aliens convicted of aggravated felonies. ${ }^{61}$ Congress subsequently expanded the group of effected aliens to include conditional permanent residents as well. ${ }^{62}$ The procedures, which are now commonly referred to as administrative removal, require notice and an opportunity to be heard, but need not be conducted before an IJ. ${ }^{63}$ The regulations interpreting this provision allow DHS (and previously INS) officers to conduct the hearings and make the decisions. ${ }^{64}$

In 1994, Congress added another specialized expulsion provision to the INA called judicial removal. Although infrequently invoked, this provision allows federal district courts to order expulsion when sentencing aliens for crimes that make them deportable. In 1996, Congress also established a special alien terrorist removal court, but to date it has never been used. ${ }^{65}$

By far the most widely-used of the specialized expulsion provisions is the expedited removal procedure that took effect in 1997. It applies to certain aliens who lack proper documentation or who use fraud or willful misrepresentation to procure documentation or admission. ${ }^{66}$ The procedure applies to such aliens if they are arriving in the United States, if they are apprehended within two years of entering the United States by sea, or if they are apprehended within 100 miles of the Mexican or Canadian border and within fourteen days of entering the United States. ${ }^{67}$ Expedited removal allows DHS

59. Immigration Reform and Control Act of 1986 (IRCA) $\S 701,8$ U.S.C. $\S 1254$ (2000).

60. See LegomsKy, supra note 28, at 834-36.

61. See Violent Crime Control and Law Enforcement Act of 1994, Pub. L. No. 103-322, $\S 130004,108$ Stat. 1796, 2026-28 (1994), amended by Pub. L. No. 103-416, § 223(a)(1), 108 Stat. 4305, 4322 (1994).

62. See Antiterrorism and Effective Death Penalty Act of 1996 (AEDPA), Pub. L. No. 104-132, $\S 442(a)(1)$.

63. See INA $\S 238(\mathrm{~b}), 8$ U.S.C. $\S 1228(\mathrm{~b})(2000)$. Although the heading in the statute is "expedited removal," "administrative removal" is the more common name so as to distinguish it from the expedited removal procedures laid out in INA section 235(b). See AlEINIKOFF ET AL., supra note 21 , at $691 \mathrm{n.1}$.

64. See 8 C.F.R. § 238.1 (2005); LEGOMSKY, supra note 28 , at 836-37.

65. See AEDPA $\S 401,110$ Stat. 1258-68 (adding INA $\S \S 501-507,8$ U.S.C. $\$ \S 1531-1537$ (2000)); Aleinikoff ET AL., supra note 21, at 1277; Peter H. Schuck, Terrorism Cases Demand New Hybrid Courts, L.A. Times, July 9, 2004, at B13.

66. Specifically, expedited removal applies to certain non-Cubans who are inadmissible under INA sections 212(a)(6)(C), 8 U.S.C. $\$ 1182(a)(2)(C)(2000)$ (misrepresentation), or 212(a)(7), 8 U.S.C. $\S 1182(a)(7)(2000)$ (failure to meet document requirements). See INA $\S 235(\mathrm{~b})(1), 8$ U.S.C. $\S 1225(\mathrm{~b})(1)(2000) ; 8$ C.F.R. $\$ 235.3$ (2005).

67. See INA $\S 235(\mathrm{~b}), 8$ U.S.C. $\$ 1225$ (b) (2000) (mandating expedited removal for arriving aliens and giving the Attorney General discretion to expand the procedure to any aliens who have been present within the United States for less than two years without having been admitted or paroled); Notice Designating Aliens Subject to Expedited Removal Under Section 235(b)(1)(A)(iii) of the Immigration and Nationality Act, 67 Fed. Reg. 68,924 (Nov. 13, 2002) (expanding expedited removal to aliens who have been present for less than two years without having been admitted or 
to remove these aliens with only minimal procedures. Unless an alien indicates a fear of persecution or torture, DHS can order the person removed as soon as it determines that he or she qualifies for expedited removal. ${ }^{68}$ If the alien indicates a fear of persecution or torture, then he or she will be interviewed by a DHS asylum officer, who must determine whether the alien's fear is credible. If the asylum officer decides that it is, then the alien will be taken out of the expedited proceedings and placed in the standard expulsion proceedings described above (with the opportunity for a full hearing before an $\mathrm{IJ}){ }^{69}$

\section{Administrative Review of Expulsion Orders}

Once a decision in the first instance has been reached, an administrative appeal may or may not be available. Aliens ordered expelled under INA section 235(c) are entitled to limited review by a District Director, but nothing more. ${ }^{70}$ Aliens subject to administrative removal are entitled to no administrative review at all. ${ }^{71}$ Finally, aliens ordered removed pursuant to expedited removal proceedings are entitled to administrative review only if they claim to fear persecution or to be lawful permanent residents, refugees or asylees. The review for such claims may be limited to an abbreviated hearing before an $\mathrm{IJ}^{72}$

When full administrative review over an expulsion decision $i$ available, it is carried out by the BIA. ${ }^{73}$ Appeals to the BIA must be filed within thirty days of a first instance expulsion order, and can be filed by DHS (previously INS), the alien, or both. ${ }^{74}$ The BIA is usually the only level of administrative review. However, its decisions may be reviewed by the Attorney General if the Attorney General so wishes, or at the request of either the BIA chairman or DHS Secretary (and previously INS Commissioner) ${ }^{75}$

The BIA is an administrative body within the Department of Justice that is separate from the INS and exists solely by virtue of the Attorney General's

paroled, and who arrived by sea); Designating Aliens for Expedited Removal, 69 Fed. Reg. 48,877 (Aug. 11, 2004) (expanding expedited removal to aliens who have been present for less than fourteen days without having been admitted or paroled, and who are apprehended within 100 miles of the Mexican or Canadian borders).

68. The removal order will be entered by the examining officer, but will become final only after it is approved by the officer's supervisor. See 8 C.F.R. $\$ 235.3(b)(7)(2005)$.

69. See INA $\S 235(\mathrm{~b})(1)(\mathrm{B})(2), 8$ U.S.C. $\S 1225(\mathrm{~b})(1)(\mathrm{B})(2)(2000) ; 8$ C.F.R. $\S 208.30(\mathrm{f})(2005)$.

70. See 8 C.F.R. $\& 235.8$ (b), (c) (2005).

71. See INA § $238($ b), 8 U.S.C. $\S 1228$ (b) (2000); 8 C.F.R. $\S 238.1$ (2005).

72. See INA $\$ 235$ (b)(1)(B)(iii)(III), (c), 8 U.S.C. $\$ 1225$ (b)(1)(B)(iii)(III), (c) (2000); 8 C.F.R. $\S \S 235.3(\mathrm{~b})(5)(\mathrm{iv}), 235.6(\mathrm{a})(2)(\mathrm{ii}), 1003.42,1235.3(\mathrm{~b})(5)(\mathrm{iv}), 1235.6(\mathrm{a})(2)(\mathrm{ii})(2005)$.

73. The BIA is not, however, the only body that conducts administrative review over decisions related to immigration. Currently, there is also an Administrative Appeals Unit, which hears certain appeals from IJs and District Directors. It is appeals from expulsion orders that we are most concerned with here, however, and these all go to the BIA. See ALEINIKOFF ET AL., supra note 21, at 254.

74. See 8 C.F.R. $\S \S 1003.3,1003.38$ (b) (2005).

75. See 8 C.F.R. $\$ 1003.1(\mathrm{~h})(2005)$. 
regulations. ${ }^{76}$ Originally composed of five permanent members, including a Chairman, and assisted by a team of staff attorneys and paralegals, the BIA used to hear all cases en banc. ${ }^{77}$ In 1988 , a rising caseload prompted the Attorney General to allow designation of up to two IJs to sit temporarily with the BIA, and for this augmented BIA to sit in panels of three. ${ }^{78}$ In 1994, the BIA was expanded to nine authorized permanent Board members (on top of temporary IJs sitting by designation). ${ }^{79}$ In addition, the panel system instituted in 1988 now became the norm, and en banc review the exception. ${ }^{80}$ The expansion continued along these lines in the succeeding years: twelve permanent members were authorized in $1995,{ }^{81}$ fifteen in $1996,{ }^{82}$ eighteen in $1998,{ }^{83}$ twenty-one in $2000,{ }^{84}$ and twenty-three in $2001 .^{85}$ In practice, however, only nineteen positions were ever filled, and in 2002 the Attorney General cut the number back down to eleven-a change that we discuss further in Part II.C. ${ }^{86}$

The BIA has two main functions: to decide individual cases, and to issue precedent decisions. The latter function is important for guiding DHS (formerly the INS) and the IJs, and also for interpreting those questions of immigration law that Congress delegates to the Attorney General. ${ }^{87}$ The BIA publishes a small number of decisions, which are selected as precedent by a majority of the permanent Board members. ${ }^{88}$ Most BIA decisions, however, are unpublished, nonprecedential decisions geared toward resolving indi-

76. See AlEINIKOFF ET AL., supra note 21, at 252.

77. See id.

78. See Executive Office for Immigration Review; Board of Immigration Appeals; Designation of Judges, 53 Fed. Reg. 15,659, 15,659-60 (May 3, 1988).

79. See Executive Office for Immigration Review; Board of Immigration Appeals; Expansion of the Board, 59 Fed. Reg. 47,231 (Sept. 15, 1994).

80. See id.

81. See Executive Office for Immigration Review; Board of Immigration Appeals; Expansion of the Board, 60 Fed. Reg. 29,469 (June 5, 1995).

82. See Executive Office for Immigration Review; Board of Immigration Appeals; Board members, 61 Fed. Reg. 59,305 (Nov. 22, 1996).

83. See Executive Office for Immigration Review; Board of Immigration Appeals; 18 Board members, 63 Fed. Reg. 51,518 (Sept. 28, 1998).

84. See Executive Office for Immigration Review; Board of Immigration Appeals; 21 Board members, 65 Fed. Reg. 20,068 (Apr. 14, 2000).

85. See Executive Office for Immigration Review; Board of Immigration Appeals; 23 Board members, 66 Fed. Reg. 47,379 (Sept. 12, 2001). This expansion in authorized Board members was accompanied by a parallel expansion in staff attorneys, who numbered about twenty-five in 1986, as compared to over 100 in 2002. See EOIR Hearing, supra note 3, at 16 (prepared statement of former Board Member Michael J. Heilman).

86. 'See Board of Immigration Appeals; Procedural Reforms to Improve Case Management, 67 Fed. Reg. 54,878, 54,878-79, 54,901 (Aug. 26, 2002); infra note 170 and accompanying text.

87. See EOIR Hearing, supra note 3, at 16 (prepared statement of former Board Member Michael J. Heilman); Maurice A. Roberts, The Board of Immigration Appeals: A Critical Appraisal, 15 SAN DIEGo L. REv. 29, 36-37 (1977).

88. See 8 C.F.R. § 1003.1(g) (2005); ILP, supra note 32, § 3.05[6][d]; see also Derek Smith, $A$ Refugee By Any Other Name: An Examination of the Board of Immigration Appeals' Actions in Asylum Cases, 75 VA. L. REV. 681, 706 (1989) (discussing the small quantity of published BIA decisions and the reasons for Board members' reluctance, in particular, to publish decisions granting asylum). 
vidual cases. These unpublished decisions were once routinely laid out in written opinions, usually a few pages in length and roughly analogous to the courts of appeals' unpublished "summary orders." Since 1999, however, unpublished BIA decisions have also included "affirmances without opinion"-two sentence decisions that simply affirm IJ decisions without any reasoning. These decisions are discussed further in Part II.C.

The bulk of the BIA's work is to provide review of the decisions of IJs in expulsion proceedings. ${ }^{89}$ The BIA also reviews a host of other decisions, by both IJs and District Directors, on issues ranging from administrative fines to visa petitions to detention. ${ }^{90}$ In addition, the BIA must decide motions to reopen or reconsider its own decisions. ${ }^{91}$

\section{Judicial Review of Expulsion Orders}

Expulsion cases wind up in federal court through a number of different mechanisms. The most common of these is the petition for review procedure laid out in the Hobbs Act. ${ }^{92}$ Originally created to govern judicial review over a number of non-immigration-related agencies, the Hobbs Act procedure was extended to the immigration setting in $1961 .^{93}$ The Act gives the courts of appeals jurisdiction to directly review certain administrative orders, bypassing the district courts. In the immigration setting, it can be used to challenge expulsion orders only after they have become final, and only if administrative remedies have been exhausted. ${ }^{94}$

In practice, this means that petitions for review are almost entirely challenges to BIA decisions. ${ }^{95}$ They include challenges to BIA decisions on

89. See ALEINIKOFF ET AL., supra note 21, at 253.

90. See 8 C.F.R. \& 1003.1(b); ILP, supra note 32, at 3.05[3]; Stephen H. Legomsky, Forum Choices for the Review of Agency Decisions: A Study of the Immigration Process, 71 Iowa L. REv. 1298, 1307-10 (1986) [hereinafter Forum Choices].

91. See 8 C.F.R. § 1003.2 (2005); ILP, supra note 32, at 3.05[7].

92. Pub. L. No. 81-901, 64 Stat. 1129 (1950) (current version at 28 U.S.C. $\$ \S 2341-2351$ (2000)).

93. See Act of Sept. 26, 1961, Pub. L. No. 87-301, \& 5, 75 Stat. 650, 651-53.

94. See INA $\S 242$ (a)(1), (d), 8 U.S.C. $\$ 1252$ (a)(1), (d). On the exhaustion requirement and the problems it creates when compounded with BIA summary dismissals, see Smith, supra note 88, at 710 n. 141 .

95. Other decisions that can be challenged through petitions for review include the decisions of the Attorney General in cases that were first decided by the BIA. In addition, administrative removal orders issued by DHS/INS pursuant to INA section 238(b) can be challenged through petitions for review, but between 1997 and the passage of the REAL ID Act, such review was severely limited by the fact that administrative removal orders are based on aggravated felony convictions. See INA $\S \S 238(b)(3), 242(a)(2)(C), 8$ U.S.C. $\$ \S 1228(b)(3), 1252(a)(2)(C)(2000)$; Alibutod v. Ashcroft, No. 02-71636, 70 Fed. App'x. 424, 424-26, 2003 WL 21500045, at *1-2 (9th Cir. 2003) (unpublished opinion) (holding that jurisdiction existed to determine whether 8 U.S.C. $\S 1252(a)(2)(C)$ barred jurisdiction, and ultimately concluding that it did). It also may be possible to use petitions for review to challenge summary removal orders issued by a District Director under INA section 235(c), given that INA section 242 speaks generally of final orders of removal, expressly limits review of expedited removal orders under INA $\S 235(\mathrm{~b})(1)$, but does not expressly limit review of orders under INA $\S 235$ (c). Cf. Rafeedie v. INS, 880 F.2d 506, $511-13$ (D.C. Cir. 1989) (holding that former INA section 106(c) did not provide for judicial review of section 235 (c) orders based on, among other things, the language of that provision); AEDPA, Pub. L. No. 104-132, § 401(b), 110 Stat. 1214, 1267 (1996) (adding language to former INA $\S 106(\mathrm{~b})$ providing for judicial review in the District of 
appeals taken directly from IJs, and also to BIA decisions on motions to reopen or reconsider. ${ }^{96}$ Petitions for review cannot be used to challenge IJ decisions that have not first been appealed to the BIA, and they cannot be used to challenge DHS (or INS) expedited removal orders under INA section 235(b)(1) ${ }^{97}$ Nor can they be used to challenge District Director decisions and other decisions made outside of expulsion proceedings. ${ }^{98}$

While petitions for review are almost entirely challenges to BIA decisions, not all BIA decisions can be challenged through petitions for review. As noted above, the BIA issues many decisions that do not involve expulsion orders, and these are generally not challengeable through petitions for review (although they may be challenged in federal court through other procedures) ${ }^{99}$ Before April 1997, only final deportation orders could be challenged through petitions for review. ${ }^{100}$ Exclusion orders had to be challenged through habeas corpus petitions in federal district court. ${ }^{101}$ The IIRIRA changed that by creating one form of expulsion proceeding, allowing petitions for review regardless of whether expulsion is based on inadmissibility, excludability or deportability grounds. ${ }^{102}$

At the same time, the IIRIRA created a number of bars to judicial review. Specifically, the Act barred review of certain discretionary determinations (not including discretionary asylum determinations), and expulsion orders based on certain criminal offenses. ${ }^{103}$ The courts interpreted these bars as stripping the courts of appeals' jurisdiction over petitions for review, while allowing the district courts to retain jurisdiction in habeas corpus proceedings. ${ }^{104}$ In addition, the courts held that they always retained jurisdiction to determine their own jurisdiction, and so could always review petitions for review for at least the limited purpose of determining whether or not they

Columbia of certain aliens ordered excluded under $\S 235(\mathrm{c})$ ). Finally, the courts of appeals receive a small number of petitions for review over which they simply lack jurisdiction (e.g., petitions challenging IJ decisions). Although these petitions tend to be dismissed fairly quickly, we mention them here because they do end up being counted for statistical purposes as petitions for review.

96. See INA $\S 242(\mathrm{~b})(6), 8$ U.S.C. $\$ 1252(\mathrm{~b})(6)(2000)$.

97. See INA $\S \S 242(\mathrm{a})(2)(A)$, (e), 8 U.S.C. $\S 1252(\mathrm{a})(2)(\mathrm{A})$, (e) (2000).

98. See Aleinikoff et Al., supra note 21, at 775-78; David A. Martin, National Judicial CENTER, MAJOR ISSUES IN IMMIGRATION LAW 95-108 (1987).

99. See MARTIN, supra note 98 . The courts have carved out some exceptions to this general rule in cases where it seems appropriate to treat a BIA decision as if it were an expulsion order, even though it does not actually order the alien expelled. See, e.g., Nreka v. Att'y Gen., 408 F.3d 1361 (11 th Cir. 2005) (upholding jurisdiction to review a BIA decision that denied asylum to a Visa Waiver Program applicant in "asylum only" proceedings); Del Pilar v. Att'y Gen., 326 F.3d 1154, 1156-57 (11 th Cir. 2003) (upholding jurisdiction over a BIA decision that reversed an IJ's grant of a waiver of inadmissibility under INA $\S 212$ (c), but remanded to the $\mathrm{IJ}$ for the sole purpose of allowing the petitioner to designate a country of removal).

100. See Act of 1961 , Pub. L. No. $87-301 \S 5$ (a) (codified at former INA $\S 106,8$ U.S.C.A. $\S 1105 a($ West 1997)).

101. See id.

102. See IIRIRA, Pub. L. No. 104-208, § 306(a)(2), 110 Stat. 3009-607 (1996) (codified at INA $\S 242,8$ U.S.C. $\S 1252(2000))$.

103. See id.; INA $\S 242(\mathrm{a})(2)(\mathrm{B}),(\mathrm{C}), 8$ U.S.C. $\S 1252(\mathrm{a})(2)(\mathrm{B}),(\mathrm{C})(2000)$

104. See INS v. St. Cyr, 533 U.S. 289 (2001). 
were barred. ${ }^{105}$ This led to a complicated system whereby some aliens were challenging their removal orders through petitions for review, others were challenging them through habeas petitions, and many were challenging them through both. ${ }^{106}$ Just recently, Congress changed all of this through the REAL ID Act. Essentially, the Act attempts to channel the issues that could have been raised in habeas petitions back into petitions for review. ${ }^{107}$ At the time of writing this article, it remains to be seen how this will be interpreted.

In terms of the mechanics of filing a petition for review, the venue and timing provisions have both been narrowed since 1971. Understanding these rules and how they have changed is critical to understanding how we estimate, in Parts IV and V, the rate at which BIA decisions are appealed. The current venue rule is that a petition must be filed in the circuit in which the IJ completed proceedings. ${ }^{108}$ As a practical matter, this means that only the First through the Eleventh Circuits have jurisdiction over petitions for review, since there are no immigration courts located within the territory of the District of Columbia Circuit. ${ }^{109}$ Before April 1, 1997, a petition could be filed in either the circuit in which the IJ "conducted [proceedings] in whole or in part" or the circuit in which the petitioner resided. ${ }^{110}$ The timing rule is currently that the petition must be filed no more than thirty days after the date of the final expulsion order. ${ }^{11}$ From January 1, 1990, through October 31, 1996, the deadline was normally ninety days, but people convicted of aggravated felonies were limited to thirty days. ${ }^{112}$ Before 1990 , the deadline was normally six months, but people convicted of aggravated felonies after

105. See, e.g., Drakes v. Ashcroft, 323 F.3d 189, 190 (2d Cir. 2003); Jobson v. Ashcroft, 326 F.3d 367, 371 (2d Cir. 2003).

106. We have only just scratched the surface of the tricky jurisdictional issues created under the AEDPA and the IIRIRA. For a much more comprehensive discussion of these issues, see Lenni B. Benson, Back to the Future: Congress Attacks the Right to Judicial Review of Immigration Proceedings, 29 Conn. L. Rev. 1411 (1997); Lenni B. Benson, The "New World" of Judicial Review of Removal Orders, 12 Geo. IMmigR. L.J. 233 (1998); Hiroshi Motomura, Judicial Review in Immigration Cases After AADC: Lessons From Civil Procedure, 14 Geo. IMMIGR. L.J. 385 (2000).

107. See Pub. L. No. 109-13, § 106, 119 Stat. 231 (2005); H.R. REP. No. 109-72 (2005).

108. See INA $\$ 242(\mathrm{~b})(2), 8$ U.S.C. $\$ 1252(\mathrm{~b})(2)$ (2000) (providing the permanent rule for removal proceedings commenced after Apr. 1, 1997); IIRIRA § 309(c)(4)(D) (providing the transitional rule for review of expulsion proceedings commenced before Apr. 1, 1997, and completed after Oct. 31, 1996).

109. See, e.g., Hadera v. INS, 136 F.3d 1338 (D.C. Cir. 1998) (noting that court lacked jurisdiction over petition for review because IJ completed proceedings within the Fourth Circuit, but dismissing due to untimeliness rather than transferring petition to Fourth Circuit). For the current location of each Immigration Court, see http://www.usdoj,gov/eoir/sibpages/lCadr.htm (last visited Apr. 17, 2005).

110. See Act of 1961, Pub. L. No. 87-301, §5(a), 75 Stat. 650, 651; 8 U.S.C.A. § 1106a(a)(2) (West 1997).

111. See INA $\S 242(b)(1), 8$ U.S.C. $\$ 1252(b)(2)$ (2000) (providing the permanent rule for removal proceedings commenced after Apr. 1, 1997); IIRIRA $\S 309(\mathrm{c})(4)(\mathrm{C})$ (providing the transitional rule for review of expulsion proceedings commenced before Apr. 1, 1997, and completed after Oct. 31, 1996).

112. See Immigration Act of 1990, Pub. L. 101-649, Title V, §§ 502(a), 545(b), 104 Stat. 5048, 5052,5065 . 
November 17,1988 , were limited to sixty days. ${ }^{113}$

\section{Clearing the BIA's Backlog}

Having reviewed the basic standards and procedures involved in expelling people from the United States, we turn now for a closer look at the BIA's procedural changes. The story begins with a rising backlog of appeals pending before the BIA in the 1990s. An increase in appealable IJ decisions, ${ }^{114}$ as well as an increase in the rate at which those decisions were appealed, ${ }^{115}$ both of which meant an overall increase in caseload for the BIA, caused this backlog. ${ }^{116}$ This increased caseload appears to have clogged not just the actual adjudication stage, but also the process of typing transcripts of the hearings under review. ${ }^{117}$ Another cause of the BIA's backlog appears to have been Congress's frequent amendments to the INA, particularly the complex changes brought about by the 1996 Antiterrorism and Effective Death Penalty Act (AEDPA) and IIRIRA. ${ }^{118}$ The number of Board members has also been suggested as a possible cause, although there is disagreement over this point. Former Board Member Lory Rosenberg attributes the backlog in part to the fact that in the early 1990s, only three of the five permanent Board member positions were filled, requiring IJs to intermittently sit on the Board. ${ }^{119}$ Former Board Member Lauren R. Mathon notes that four of the Board members appointed between 2000 and 2001 had no background in immigration law, and therefore needed time to become

113. See Act of 1961, Pub. L. No. 87-301, § 5(a), 75 Stat. 650, 651; Anti-Drug Abuse Act of 1988, Pub. L. No. 690, \& 7347(a), 102 Stat. $4181,4472$.

114. The Dorsey \& Whitney report explains that the 1990's saw both record immigration to the United States, and also a huge increase in expulsion. There were 30,039 expulsion proceedings in 1990 as compared to 185,731 in 2000. See DORSEY \& WhITNEY LLP, supra note 5, at 12-13. The rise in expulsions was at least partly caused by Congress's expansion of the crime-related deportability grounds. See Rosenberg, supra note 5, at 93-94. To keep up with the expanded caseload, the number of IJs was increased from seventy-five in 1987 to over 225 in 2002. See EOIR Hearing, supra note 3, at 9 (prepared statement of former Board Member Lauren R. Mathon). It may have also been caused by the rise in asylum claims at the end of the 1980's and early 1990's. This rise has been linked to the enforcement of sanctions against employers who hire undocumented aliens, and the fact that employment authorization could be quickly obtained by filing an asylum application. See David A. Martin, Reforming Asylum Adjudication: On Navigating the Coast of Bohemia, 138 U. PA. L. REv. 1247, 1326-27 (1990); Philip G. Schrag, A Well-Founded Fear, The Congressional Battle to SAVE Political ASYlum IN AMERICA 32 (2000); AleinikofF ET AL., supra note 21, at 842; Schuck \& Wang, supra note 11 , at $165-66 \mathrm{nn} .232-33$.

115. See EOIR Hearing, supra note 3, at 22 (prepared statement of EOIR Director Kevin D. Rooney) (noting that $10.9 \%$ of Immigration Court decisions were appealed to the BIA in fiscal year 1996 , as compared with $15.7 \%$ in fiscal year 2001 ).

116. See, e.g., EOIR Hearing, supra note 3, at 27 (prepared statement of Stephen Yale-Loehr) (noting a ten-fold increase between fiscal year 1984, when the BIA received less than 3000 cases and fiscal year 2000, when the BIA received almost 30,000).

117. See Schrag, supra note 5, at 541; Board of Immigration Appeals: Procedural Reforms to Improve Case Management, 67 Fed. Reg. 54,878, 54,895 (Aug. 26, 2002).

118. See EOIR Hearing, supra note 3, at 9 (prepared statement of former Board Member Lauren R. Mathon); id. at 22-23; DORSEY \& WHITNEY LLP, supra note 5, at 14.

119. See Rosenberg, supra note 5, at 93. 
proficient in their work. ${ }^{120}$ On the other hand, EOIR Director Kevin Rooney argues that the increase in authorized Board members during the 1990s from five to twenty-three had "no appreciable impact" on the annual completion of cases. ${ }^{121}$

Whatever the causes, the BIA ended up with over 47,000 pending cases in 1998 and over 57,000 in 2001. ${ }^{122}$ It was in the face of this staggering backlog that the BIA began a series of procedural changes aimed at speeding up its case-processing time. The first step was a regulation in October 1999 that established "streamlined appellate review procedures" for the BIA. ${ }^{123}$

\section{October 1999 "Streamlining" Regulation}

The October 1999 regulation authorized the Board Chairman to designate certain categories of cases as suitable for review by single Board members. ${ }^{124}$ It authorized the single Board members hearing these cases to affirm without opinion if they determined that:

[T]he result reached in the decision ... was correct; that any errors in the decision ... were harmless or nonmaterial; and that $(\mathrm{A})$ the issue on appeal is squarely controlled by existing Board or federal court precedent and does not involve the application of precedent to a novel fact situation; or (B) the factual and legal questions raised on appeal are so insubstantial that three-member review is not warranted. ${ }^{125}$

The regulation also authorized individual Board members to summarily dismiss appeals, and it slightly expanded the existing grounds for summary

120. See EOIR Hearing, supra note 3, at 22. At the same time, however, former Board Member Mathon argues the optimum number of Board members is sixteen, and former Board Member Michael J. Heilman argues that the number is nine. See EOIR Hearing, supra note 3, at 10, 18. Their arguments for reducing the Board from its pre-2002 size of twenty-three members, however, are based more on the need for collegiality and coherence in issuing precedent decisions than on an assertion that a smaller board would decide more cases overall. See EOIR Hearing, supra note 3, at 16 (prepared statement of Michael J. Heilman) ("It was inevitable that the ability of the BIA to issue precedent decisions, to say nothing of useful precedent decisions, would be lowered as the number of Board members increased."); $c f$. id. ("The simple equation applied [which ignored the BIA's precedent-setting role], was that more members would equal more cases decided, which was more or less the result, without regard to output per member, which has varied greatly.").

121. See EOIR Hearing, supra note 3, at 20; see also DORSEY \& WHITNEY LLP, supra note 5, at 14-15 nn.37-38 (citing comments by the Federation for American Immigration Reform and from Congressional staffers who argued that the increase in Board members actually added to the backlog). Another asserted cause for the backlog is management problems within the BIA from 1995 to 2000 .

See EOIR Hearing, supra note 3, at 9 (prepared statement of Lauren R. Mathon).

122. The most comprehensive calculations of the BIA's backlog can be found in DORSEY \& WHITNEY LLP, supra note 5, at apps. 11-13.

123. Executive Office for Immigration Review; Board of Immigration Appeals: Streamlining, 64 Fed. Reg. 56,135 (Oct. 18, 1999).

124. See id. at 56,141 .

125. Id. 
dismissal. ${ }^{126}$ In the case of individual member affirmance without opinion and individual member summary dismissal, the regulation directed the single member to send the appeal to a three-member panel if he or she determined that it was not appropriate for summary procedures. ${ }^{127}$ Finally, the regulation authorized individual Board members to act alone in disposing of certain procedural and ministerial matters, such as remands due to defective or missing transcripts. ${ }^{28}$

The BIA implemented this regulation in phases. The first two phases involved "converting certain categories of cases to single Board member review." ${ }^{129}$ Single Board members decided cases during this phase, but they did not yet employ affirmances without opinion. ${ }^{130}$ Phase III, which began in September 2000 , was a pilot project designed to test the organizational structures and procedures by which streamlining would be implemented. The EOIR hired Arthur Andersen \& Company to conduct an independent evaluation of the effectiveness of this phase, and to make recommendations regarding the permanent implementation of the streamlining regulation. ${ }^{131}$ Phase III marked the point when the BIA first began issuing affirmances without opinion. ${ }^{132}$ On August 28, 2000, the BIA Chairman designated the following categories of cases appropriate for single-member affirmance without opinion: ${ }^{133}$

- Certain appeals from visa petitions;

- Appeals from IJ denials of untimely or number-barred motions and certain motions to reopen to apply for suspension of deportation;

\footnotetext{
126. See id. at $56,141-42$. Before the 1999 regulation, summary dismissals were authorized where: (1) the appealing party failed to specify the reasons for the appeal; (2) the party conceded all of the legal and factual issues raised in the appeal in prior proceedings; (3) the appeal was from an order that granted the party the relief requested; (4) the appeal was filed for an improper purpose; (5) the party indicated that he or she would file a brief or statement on appeal, and then failed to do so; (6) the appeal failed to meet essential statutory or regulatory requirements or was barred by statute or regulation. See 8 C.F.R. \& 3.1 (1988), reprinted in DORSEY \& WHITNEY LLP, supra note 5, at app. 15. The 1999 regulation then added new grounds based on (1) lack of jurisdiction, and (2) untimeliness of appeal or clear waiver of right to appeal. See 64 Fed. Reg. at 56,141.

127. See 64 Fed. Reg. at 56,141-42.

128. Specifically it authorized single members to: (1) remand appeals from denials of visa petitions when requested by a Regional Service Center Director, (2) remand appeals in which there is a defective or missing transcript that needs to be corrected, and (3) dispose of other procedural and ministerial matters as provided by the Chairman. See id. at 56,141 .

129. Executive Office for Immigration Review, Board of Immigration Appeals (BIA) Streamlining Pilot Project Assessment Report 1, 3 (2001) [hereinafter Andersen Assessment], reprinted in DORSEY \& WhITNEY LLP, supra note 5, at app. 21.

130. See infra app. Table 20 (presenting data provided by the EOIR in response to our FOIA request).

131. See Andersen Assessment supra note 129, at 1.

132. See infra app. Table 20 (presenting data provided by the EOIR in response to our FOIA request).

133. See Memorandum from Paul W. Schmidt, Chairman, Board of Immigration Appeals, to all Board members of the Board of Immigration Appeals (Aug. 28, 2000), available at http:// www.usdoj.gov/eoir/vll/genifo/stream.htm, reprinted in DORSEY \& WHITNEY LLP, supra note 5, at app. 3.
} 
- Appeals from IJ orders finding deportability or inadmissibility where the underlying facts were not in dispute and there was "no substantial question" that the alien was deportable or inadmissible;

- Appeals in which the alien contested, in the face of "settled" law, that a particular offense could form the basis for inadmissibility or deportability;

- Appeals in which the alien sought relief from deportation or removal based on the Geneva Convention Relative to the Protection of Civilian Persons in Time of War;

- Appeals involving claims for asylum barred by an aggravated felony conviction unless there was a "substantial legal question" whether the alien was convicted of an aggravated felony;

- Certain appeals involving withholding of deportation or removal that were statutorily barred based on criminal convictions;

- Appeals involving claims for waivers of smuggling grounds where the required family relationship was not present;

- Appeals involving certain time-barred claims for suspension of deportation or cancellation of removal;

- Certain appeals involving a claim for registry;

- Appeals involving collateral attacks on underlying convictions;

- Appeals in which the alien claimed citizenship or lawful permanent resident status but lacked supporting evidence.

On November 1, 2000, the Chairman expanded these categories to also include: ${ }^{134}$

- Appeals from an IJ's order finding deportability or inadmissibility where the underlying facts were not in dispute, there was no substantial question that the alien was deportable or inadmissible and it was clear from the statute, regulation or BIA precedent that the alien was ineligible for any form of relief requested on appeal;

- Certain appeals in which the alien was denied cancellation of removal.

In practice, streamlining relied heavily on the BIA's team of staff attorneys and paralegals. This staff was involved in not only recommending outcomes and drafting opinions, but also determining which cases would be sent to single Board members for summary affirmance. ${ }^{135}$ When those Board

134. See Memorandum from Paul W. Schmidt to Board members, (Nov. 1, 2000), available at http://www.usdoj,gov/eoir/vll/genifo/stream.htm, reprinted in DORSEY \& WhITNEY LLP, supra note 5, at app. 17.

135. See Andersen Assessment, supra note 129, at 9 (noting that of the group of cases referred for streamlining during the pilot project, $45 \%$ were rejected from being streamlined, and the "overwhelming majority" of these were rejected by staff attorneys or paralegals). Former Board Member Lory D. 
members decided to affirm without opinion, they did so by issuing boilerplate decisions stating: "The Board affirms, without opinion, the result of the decision below. The decision below is, therefore, the final agency determination." 136

The Phase III Pilot Project lasted from September 2000 through August 2001. Arthur Andersen assessed the extent to which the Project achieved the goal of "increas[ing] productivity of fair and legally correct decisions in a program that can be sustained over an extended period of time." ${ }^{137}$ Andersen found that the "overwhelming" weight of the evidence it analyzed indicated that the project had been an "unqualified success."138 It acknowledged, however, that streamlining had not been in place for long enough to provide an objective evaluation of its effects on the quality of decisions rendered. ${ }^{139}$ Its conclusion that streamlining produced fair and legally correct decisions was therefore based largely on a survey of forty-eight EOIR staff members, twenty-nine of whom "agreed" or "strongly agreed" with such a conclusion. ${ }^{140}$

In its December 2001 assessment, Andersen also proposed a program for evaluating the permanent implementation of streamlining, which was to constitute Phase IV. Among other things, it recommended that data be gathered on BIA outcomes and on the rate at which BIA decisions are challenged in federal court. ${ }^{141}$ Soon after the report was released, however, the Attorney General proposed new procedural changes for dealing with the backlog. ${ }^{142}$ The BIA significantly expanded its use of streamlining while that regulation was in the notice and comment period, and it does not appear that the data collection and evaluation that Andersen recommended was ever

Rosenberg writes that, at least under the 2002 regulation, staff attorneys made the initial decision to send a case to a single Board member, and that it was then up to that Board member whether to affirm without opinion or refer the case instead to a panel. See Rosenberg, supra note 5, at 96; see also EOIR Hearing, supra note 3, at 15 (prepared statement of Michael J. Heilman) (discussing the role of the staff attorneys prior to 2002, although not stating who made the initial streamlining determinations).

136. See 64 Fed. Reg. at 56,141 .

137. Andersen Assessment, supra note 129 , at $4, \mathrm{~A}-3$ to A-4.

138. Id. at 1 .

139. Id. at 8 .

140. Id. at 11, E-2. Sixteen of the surveyed staff members professed neutrality and three disagreed. Andersen stated that "the large number of 'neutral' responses were provided by nonstreamlining associated staff members." Id.; see also Capital Area Immigrants' Rights Coal. v. U.S. Dep't of Justice, 264 F.Supp. 2d 14, 29 n.12 (D.D.C. 2003). The only other bases for Andersen's conclusion with regard to fair and legally correct decisions were: (1) a calculation that streamlining had not been used disproportionately for unrepresented aliens, and (2) a calculation that $28 \%$ of the streamlining decisions rendered during the study were "favorable" to appellants. Id. at 10 . These "favorable" decisions, however, presumably included a large number of remands due to defective or missing records and other procedural or ministerial issues, since the regulation did not allow single Board members to actually reverse IJs on the merits. See 64 Fed. Reg. at 56,141-42.

141. Andersen Assessment, supra note 129, at C-4 to C-5.

142. Attorney General John Ashcroft, News Conference: Administrative Change to Board of Immigration Appeals (Feb. 6, 2002), available at rtsp://cspanrm.fplive.net/cspan/fdrive/ ter020602_ashcroft.rm; transcript available at http://www.usdoj.gov/ag/speeches/2002/020602transcriptadministrativechangetobia.htm. 
completed. $^{143}$

\section{March 2002 Expansion of Streamlining}

The first major expansion of streamlining came on March 15, 2002, when the BIA Chairman added two large categories to the list of appeals eligible for single-member affirmance without opinion: ${ }^{144}$

- Cases involving claims for asylum, withholding ${ }^{145}$ and Convention Against Torture (CAT) relief; and

- Cases involving claims for suspension of deportation or cancellation of removal.

These categories combined probably constituted the majority of the BIA's caseload; and unlike the categories designated in 2000, these categories were not limited by additional criteria.

On May 3, 2002, the Chairman effectively abandoned the category system altogether by designating:

- All cases involving appeals of IJ or INS decisions, so long as the BIA had jurisdiction and so long as the cases met the regulatory requirement for streamlining (i.e., correct result, only harmless or nonmaterial errors, and issues either squarely controlled by existing precedent or insubstantial). ${ }^{146}$

\section{September 2002 "Procedural Reforms" Regulation}

The Justice Department published the final version of its new "Procedural Reforms To Improve Case Management" on August 26, 2002. The regulation became effective a month later and it remains the law today. The "Procedural Reforms" essentially codify and expand the procedural changes implemented

143. As of August 2002, the Justice Department appeared to be concerned that such an evaluation could take years, and it was noncommittal as to whether it would be undertaken. See Board of Immigration Appeals: Procedural Reforms to Improve Case Management, 67 Fed. Reg. 54,878, 54,885 (Aug. 26, 2002). In 2003, the EOIR declined to participate in a streamlining study conducted by Dorsey \& Whitney LLP on behalf of the American Bar Association's Commission on Immigration Policy, Practice and Pro Bono. See Letter from Susan M. Eastwood, Public Affairs Specialist, U.S. Dep't of Justice, Executive Office for Immigration Review, Office of Management Programs, to Kathleen A. Moccio, Dorsey \& Whitney LLP, reprinted in DORSEY \& WHITNEY LLP, supra note 5, at app. 2.

144. See Memorandum from Lori L. Scialabba to all BIA members (Mar. 15, 2002), reprinted in DORSEY \& WhITNEY LLP, supra note 5, at app. 22.

145. Although the Chairman's memorandum referred specifically to "Withholding of Deportation," we assume that this encompassed both the old INA section 243(h) relief as well as the current INA section 241(b)(3) relief.

146. Memorandum from Lori L. Scialabba to all BIA members (May 3, 2002), reprinted in DORSEY \& WHITNEY LLP, supra note 5, at app. 23. 
by the BIA starting in March $2002 .^{147}$

Instead of the categories of cases envisioned under the 1999 "Streamlining," the new regulation makes single-member adjudication the default procedure, with three-member panels the exception. Three-member review is permitted only for cases that present the need to (1) settle inconsistencies among IJ rulings; (2) establish precedent; (3) review a legal error; (4) resolve a case or controversy of national import; (5) review a clearly erroneous factual determination by an $\mathrm{IJ}$; or (6) reverse the decision of an $\mathrm{IJ}$ in.cases other than where reversal is "plainly consistent" with intervening law. ${ }^{148}$ Furthermore, all cases are initially assigned to single Board members, and they decide if three-member review is appropriate. When single Board members decide cases on the merits, they are authorized to affirm without opinion, as was the case in the 1999 regulation, if the IJ reached the correct result with only harmless or nonmaterial errors, and if the issues on appeal are either squarely controlled by existing precedent or insubstantial. ${ }^{149}$

The 2002 regulation also expands the grounds for summary dismissal (which is now undertaken by the screening panel) to include cases in which:

[t]he Board is satisfied, from a review of the record, that the appeal is filed for an improper purpose, such as to cause unnecessary delay, or that the appeal lacks an arguable basis in fact or in law unless the Board determines that it is supported by a good faith argument for extension, modification, or reversal of existing law. ${ }^{150}$

In addition, the regulation restricts the BIA's standard of review of an IJ's factual findings. Whereas the BIA had previously reviewed such findings de novo, it is now required to defer to them unless they are clearly erroneous. ${ }^{151}$

Finally, (in addition to various other changes) the regulation reduces the number of authorized Board members from twenty-three to eleven. The stated rationale for this last change is to improve the BIA's "cohesiveness and collegiality," addressing the concerns of some that the BIA was being weighed down by its own size. ${ }^{152}$ The regulation does not provide guidelines or specific factors to be used in deciding which Board members to eliminate, but states that the Department of Justice "expects that the final determinations will be made on [such factors as] ... integrity ..., professional competence, and adjudicatory temperament." 153 The regulation provides that seniority might be an "experience indicator" but not "a presumptive factor," and that "[e]ach Board member is a Department of Justice attorney, who is

147. See Dorsey \& Whitney LLP, supra note 5, at 19.

148. 8 C.F.R. \& 1003.1(e) (2005).

149. 8 C.F.R. $\$ 1003.1(\mathrm{e})(4)(2005)$.

150. 8 C.F.R. $\$ 1003.1(\mathrm{~d})(2)(2005)$.

151. 8 C.F.R. $\$ 1003.1$ (d)(3)(i) (2005).

152. 67 Fed. Reg. at 54,893-94.

153. Id. at 54,893 . 
appointed by, and may be removed or reassigned by, the Attorney General."154 In March 2003, Attorney General Ashcroft announced the names of five members who would be removed from the BIA in order to bring its size down to eleven. These people were "reassigned" to IJ positions or to non-adjudicative positions within the EOIR. ${ }^{155}$

\section{Criticism and Litigation}

The BIA's procedural changes are extremely controversial and have resulted in a large amount of litigation. Aliens filed petitions for review to challenge the affirmance without opinion procedure on its face in each of the eleven courts of appeals with jurisdiction over such petitions. ${ }^{156}$ These facial challenges were based on both due process and basic rules of administrative law, but every one of them has now been rejected. ${ }^{157}$ An Administrative Procedure Act suit was also brought in the U.S. District Court for the District of Columbia, arguing that the Department of Justice acted arbitrarily and capriciously in promulgating the September 2002 "Procedural Reforms" regulation. The District Court rejected this argument on May 21, 2003, and its ruling does not appear to have been appealed. ${ }^{158}$ While a few courts have upheld challenges to the application of the BIA's summary procedures in specific cases, ${ }^{159}$ the immigration bar appears to have largely given up on the facial and rule-making challenges. ${ }^{160}$

Apart from legal challenges, however, criticism of the procedural changes continues to be voiced loudly by lawyers, ${ }^{161}$ scholars, ${ }^{162}$ members of

154. Id.

155. See Legomsky, supra note 54.

156. The circuits with jurisdiction over petitions for review are the First through the Eleventh Circuits. See supra note 109 and accompanying text.

157. See Blanco de Belbruno v. Ashcroft, 362 F.3d 272, 280-83 (4th Cir. 2004); Zhang v. U.S. Dep't of Justice, 362 F.3d 155, 156-59 (2d Cir. 2004); Yuk v. Ashcroft, 355 F.3d 1222, 1229-32 (10th Cir. 2004); Loulou v. Ashcroft, 354 F.3d 706, 708-09 (8th Cir. 2004); Dia v. Ashcroft, 353 F.3d 228, 238-45 (3d Cir. 2003); Denko v. INS, 351 F.3d 717, 725-30 (6th Cir. 2003); Falcon Carriche v. Ashcroft, 350 F.3d 845, 849-52 (9th Cir. 2003); Georgis v. Ashcroft, 328 F.3d 962, 966-67 (7th Cir. 2003); Mendoza v. U.S. Att'y Gen., 327 F.3d 1283, 1288-89 (11 th Cir. 2003); Soadjede v. Ashcroft, 324 F.3d 830, 831-33 (5th Cir. 2003); Albathani v. INS, 318 F.3d 365, 375-79 (1st Cir. 2003); see also Reyes Vasquez v. Ashcroft, 395 F.3d 903, 906 (8th Cir. 2005) (rejecting challenge based on separation of powers).

158. See Capital Area Immigrants' Rights Coal. v. U.S. Dep't of Justice, 264 F. Supp. 2d 14, 39 (D.D.C. 2001) (granting summary judgment in favor of defendants); see also Capital Area Immigrants' Rights Coal. v. U.S. Dep't of Justice, No. 02-2081 (D.D.C. Mar. 31, 2003) (unpublished decision denying plaintiffs' motion for preliminary injunction).

159. See Smriko v. Ashcroft, 387 F.3d 279, 297 (3d Cir. 2004); Chen v. Ashcroft, 378 F.3d 1081, 1087 (9th Cir. 2004), petition for rehearing en banc pending.

160. See Mary Kenney, Practice Advisory, BIA "Affirmance Without Opinion": What Federal Court Challenges Remain (Apr. 27, 2005), at 1-2, available at http://www.ailf.org/lac/ lac_pa_042705.pdf.

161. For example, Moore \& Simmons, supra note 17, quotes Los Angeles immigration lawyer Carl Shusterman as stating, "Why even have a BIA? You might as well go from the judge to the [circuit] court and save the person the money of having to go to the BIA."

162. For example, Brune, supra note 17, at 3, quotes New York University law professor Nancy Morawetz as stating, "The idea that you could just rubber stamp a lot of cases at the agency and they 
Congress ${ }^{163}$ and even by IJs ${ }^{164}$ and a former Board member. ${ }^{165}$ Many critics assert that the changes undermine the four basic goals of any administrative process: accuracy, efficiency, acceptability, and consistency. ${ }^{166}$ They argue that single board members are bound to create more errors than threemember panels, especially when allowed to make decisions without a written explanation and when required to give deference to IJ factual findings. ${ }^{167}$

would go away was just mistaken." Cooper \& Bazar, supra note 17, at A1, quotes Heritage Foundation Fellow Paul Rosenzweig as describing the changes as "a transference of costs from the executive branch to the courts."

163. For example, Sen. Patrick Leahy recently issued a written statement that "[i]f the Attorney General wants to reduce the immigration workload of our federal courts, he should restore the fair appeals process within the Justice Department that his predecessor diminished through his misguided restructuring of the Board of Immigration Appeals," available at http://leahy.senate.gov/press/200502/ 022805b.html (last visited Nov. 27, 2005). Cooper \& Bazar, supra note 17, at Al, quotes Rep. Howard Berman as remarking that "[i]n the absolutely necessary effort to plug up the flaws in the system, we have taken any modicum of justice out of the immigration review process."

164. For example, Moore \& Simmons, supra note 17, at 4, quotes Immigration Judge Dana Leigh Marks, President of the National Association of Immigration Judges:

Immigration judges have begun to look really bad in the circuit court decisions because the BIA used to review things. We were encouraged to do things in a short-and-dirty manner, knowing that the BIA would return them if we went too far. . . Now, the BIA is issuing all of these affirmances without opinion and we have no resources to do a top-notch job from the beginning. ... We're like the guy behind the curtain in 'The Wizard of $\mathrm{Oz}$,' for God's sake.

165. See Rosenberg, supra note 5.

166. See, e.g., EOIR Hearing, supra note 3, at 24-33 (testimony and prepared statement of Stephen Yale-Loehr). The four goals of administrative processes are discussed in the immigration setting in Forum Choices, supra note 90, at 1313 (drawing on Roger C. Cramton, Administrative Procedure Reform: The Effects of S. 1663 on the Conduct of Federal Rate Proceedings, 16 ADMIN. L. REv. 108, 111-12 (1964); Ronald A. Cass, Agency Review of Administrative Law Judges' Decisions, in Admin. Conf. Of THE U.S., ReCommendations \& RePORTS 115, 154-57 (1983); David P. Currie \& Frank I. Goodman, Judicial Review of Federal Administrative Action: Quest for the Optimum Forum, 75 Colum. L. ReV. 1, 4 (1975)).

167. See, e.g., ABA Report, supra note 8, at 3-4; Schrag, supra note 5, at 534-35. The problems associated with rendering decisions without a reasoned opinion have been pointed out in a number of other contexts as well. Professor Schrag discusses the controversy surrounding affirmances without opinion issued before 1989 by the New York Supreme Court's Appellate Division. See id. at 536; see also Martin Fox, Appeals Court to Alter Policy on Affirmances, N.Y.L.J., Sept. 27, 1989, at 1; Roger Parloff, First Dept. Pledges to Write Opinions for All Appeals, ManhatTan Law., Oct. 3, 1989, at 4; Daniel Markewich, Civil ANOPACs Pose Problems, ManhatTan Law., Sept. 18, 1989, at 15; Roger Parloff, 'Affirmed. No Opinion. All Concur.', Manhattan Law., Aug. 29, 1989, at 1; Bulger v. McClay, 575 F.2d 407 ( $2 \mathrm{~d}$ Cir. 1978). Controversy also surrounds the federal courts' use of summary decisions. Judge Patricia Wald writes of unpublished summary dispositions:

There is . . . a worrisome 'lost horizon' aspect to no-opinion dispositions. Even when judges agree on a proposed result after reading briefs and hearing arguments, the true test comes when the writing judge reasons it out on paper (or on computer). That process, more than the vote at conference or the courtroom dialogue, puts the writer on the line, reminds her with each tap of the key that she will be held responsible for the logic and persuasiveness of the reasoning and its implications for the larger body of circuit or national law. . . But writing to explain a preordained result with no concern for its precedential effect under a self-imposed time constraint of hours is something else entirely, inviting no backward looks or self-doubt. Rhetoric will always be tied to import and permanence, and its absence in unpublished decisions signifies that they are the product of a different and much-abbreviated decisionmaking process.

Patricia M. Wald, The Rhetoric of Results and the Results of Rhetoric: Judicial Writings, 62 U. CHI. L. REv. 1371, 1374-75 (1995). 
Such adjudication, they argue, leads to inconsistency at both the BIA and of the IJ levels. ${ }^{168}$ Even aside from these deficiencies, critics argue that single-member affirmances without opinion are unlikely to be accepted as legitimate by losing parties, ${ }^{169}$ and acceptability is further undermined by the widely-held perception that the reduction in the size of the BIA was a way to remove Board members who tended to disagree with the Attorney General and reduce the independence of the remaining members. ${ }^{170}$ All of this, it is argued, results in an overall decrease in efficiency because the BIA's backlog has simply been dumped onto the federal courts. ${ }^{171}$

This criticism-especially the point about shifting the backlog-has obvious bearing on our inquiry into the surge in petitions for review. Did the procedural changes result in a higher rate of appeal because they increased errors and inconsistency and undermined litigants' confidence in the BIA? The EOIR has taken a clear position that this is not the case. It asserts that people are appealing BIA decisions at a higher rate simply to delay being expelled in the face of more prompt BIA decisions. ${ }^{172}$

The explanations for the immigration surge offered by both the critics and the EOIR raise valid concerns about immigration litigation that were noted by observers long before the present controversy began. In his 1986 study on the structure of the system of review of immigration adjudication, Professor Stephen Legomsky noted that "[o]ne who is currently receiving a benefit from the government generally has an interest in prolonging a governmental decision whether to terminate that benefit, even though that interest might be partly offset by a longing for the certainty that a final decision will bring." 173 Minimizing review time is therefore an important way to decrease the incentive to file a frivolous appeal to achieve delay. He went on to warn, however, that:

[s]tatements urging that procedures be "streamlined" are easy to make and difficult to resist. The abuses attributable to the particular proce-

168. See, e.g., Memorandum of Points and Authorities in Support of the Plaintiffs' Motion for Summary Judgement at 26-27, Capital Area Immigrants' Rights Coal. v. U.S. Dep't of Justice, 264 F. Supp. 2d 14 (D.D.C. 2001) (No. 02-3081) (pointing out that the Department of Justice "rejected widespread use of single-member review" in 1999 based on concerns over consistency). For a much earlier critique of the BIA's summary dismissal procedure, asserting that it limits the BIA's ability to supervise the adjudicative process, see Smith, supra note 88, at 708-11.

169. See, e.g., Schrag, supra note 5 , at 534 .

170. This perception is noted in ALEINIKOFF ET AL., supra note 21, at 253; DORSEY \& WhITNEY LLP, supra note 5, at 27-28; 67 Fed. Reg. at 54,893-94 (discussing the comments received during the rule-making process); EOIR Hearing, supra note 3, at 29-30 (prepared statement of Stephen Yale-Loehr). Two recent articles argue forcefully that these feared results-the removal of Board members based on ideology and the loss of decisional independence-have, in fact, occurred. Legomsky, supra note 54; Peter J. Levinson, The Facade of Quasi-Judicial Independence in Immigration Appellate Adjudications, 9 BENDER's IMMIGR. BULL. 2 (2004).

171. See, e.g., DORSEY \& WhITNEY LLP, supra note 5, at 40-41; see generally Legomsky, supra note 54 , at 717-25 (discussing the streamlining of the BIA).

172. EOIR Fact Sheet, supra note 9.

173. Forum Choices, supra note 90 , at 1330. 
dural step criticized might be small in scale, or the elimination of that step might remove important protections for the individual or indirectly add work or delay at other stages. ${ }^{174}$

This concern was noted even earlier, in a 1977 article by former Board Chairman Maurice Roberts:

In terms of actual cost to the Government, good Board decisions are a bargain. More opinions can be ground out, of course, in less time and with an even more inadequate staff; but the resulting dilution in quality, while not only unfair to the parties involved, would also cost much more in the long run. Economies of this sort can only result in passing the buck to others with less expertise. The slack would have to be taken up elsewhere in the Department; if not, the already overburdened courts will have to confront the task, for dilution in quality of Board decisions can only cause greater recourse to the courts for redress. If Service errors are to be screened out and corrected, it is more efficient in the long run that this be done by the Board. ${ }^{175}$

\section{Sources AND METHOdOLOGY}

In order to observe and try to explain the increase in petitions for review of BIA decisions, we relied mostly on three basic sources of statistical information: the federal courts, the EOIR/BIA, and DHS. Each of these entities regularly publishes statistical reports that have become familiar to anyone researching patterns of immigration litigation. ${ }^{176}$ These reports, however, are geared towards answering questions on case processing and enforcement that come up every year, and they lack some critical details needed to answer our specific questions about the immigration surge. In order to obtain this detailed information, we have gone behind the federal courts and EOIR reports and accessed some of the raw data on which the reports are based. We have also gathered our own data by examining individual case files in samples drawn from the Second Circuit and the BIA. We discuss below each of our sources and the methodology we used for gathering and compiling information. ${ }^{177}$

174. Id. at 1331 .

175. Maurice A. Roberts, The Board of Immigration Appeals: A Critical Approach, 15 SAN DIEGO L. REv. 29 (1977).

176. The most important of these are the annual reports: ADMINISTRATIVE OFFICE OF THE U.S. COURTS, JUdiCIAL Business, available at http://www.uscourts.gov/judbususc/judbus.html (last visited May 31, 2005); EOIR, OfFice of Planning and Analysis, Statistical Year Book, available at http://www.usdoj.gov/eoir/statspub/syb2000main.htm (last visited May 31, 2005); DHS, OFFICE oF ImMigration Statistics, YearboOK of IMMigRation Statistics, available at http://www.uscis.gov/ graphics/shared/statistics/yearbook/index.htm (last visited May 31, 2005).

177. For an overview of the types of sources and methodologies often used in empirical legal research, see Kevin M. Clermont \& Theodore Eisenberg, Litigation Realities, 88 CoRNEll L. REv. $119,125-29(2002)$. 


\section{A. Administrative Office $(A O)$ Data Series}

The federal courts have long been recording statistical information about their work, and much of this data is readily available from the Interuniversity Consortium for Political and Social Research (ICPSR). ${ }^{178}$ Specifically, the ICPSR disseminates a series of data sets gathered and assembled by the Administrative Office of the U.S. Courts (AO) and the Federal Judicial Center (FJC). ${ }^{179}$ The data in these sets originate from each of the federal district courts and non-specialized federal appellate courts in the country. ${ }^{180}$ For every case that is filed and for every case that terminates in one of these courts, the court clerk sends the $\mathrm{AO}$ a form containing information about the case. The AO compiles this information each year into two data sets, one for cases terminated during that year and the other for cases still pending at the end of that year. The AO then passes these sets on to the FJC for further processing, ${ }^{181}$ and the FJC passes the final product to the ICPSR for dissemination on its Web site. ${ }^{182}$

For cases in the courts of appeals, the available data sets begin with statistical year 1971 (July 1970 though June 1971) and end with fiscal year 2003 (October 2002 through September 2003). ${ }^{183}$ We downloaded each of the AO data sets for terminated appeals and combined them in a single database. ${ }^{184}$ We then added data on the petitions for review terminated during

178. See http://www.icpsr.umich.edu (last visited May 27, 2005).

179. The $A O$ is an administrative arm of the federal judiciary that generally provides administrative support, program management and policy development to the courts, and implements the policies of the Judicial Conference of the United States. See 28 U.S.C. $\$ \S 601-13$ (2000); Administrative Office of the United States Courts, http://www.uscourts.gov/adminoff.html (last visited May 28, 2005). The FJC is the federal courts' education and research agency. See 28 U.S.C. $\$ \S 620-29$ (2000); Federal Judicial Center, http://www.fjc.gov (last visited May 28, 2005).

180. The non-specialized federal appellate courts are the U.S. Courts of Appeals for the First through Eleventh Circuits and for the District of Columbia Circuit. These stand in contrast to the specialized appellate courts, which exercise appellate jurisdiction over particular subject matter (e.g., the U.S. Court of Appeals for the Federal Circuit) or over the decisions of specialized district courts for federal territories (e.g., the District of Columbia Court of Appeals-not to be confused with the U.S. Court of Appeals for the District of Columbia Circuit). See generally Charles Alan Wright, Arthur R. Miller, Edward H. Cooper \& Richard. D. Freer, 13 Federal Practice and Procedure $\S 3508$ (1984 \& Supp. 2005).

181. The AO also uses this information as the basis for its published statistical reports, http://www.uscourts.gov/judbususc/judbus.html (last visited May 25, 2004). While these reports provide some information about petitions for review of BIA decisions (under the category label "INS") much more is gained by turning directly to the underlying data sets.

182. The series can be found at http://www.icpsr.umich.edu, under the title "Federal Court Cases: Integrated Database Series." For further information on the AO data, see generally Theodore Eisenberg \& Margo Schlanger, The Reliability of the Administrative Office of the U.S. Courts Database: An Initial Empirical Analysis, 78 Notre Dame L. Rev. 1455 (2003); Kevin M. Clermont \& Theodore Eisenberg, Do Case Outcomes Really Reveal Anything About the Legal System? Win Rates and Removal Jurisdiction, 83 CORNELL L. REv. 581, 585-87 (1998).

183. The switch from statistical year to fiscal year reporting occurred in the 1992 data set, which spans the fifteen month period from July 1991 through September 1992. See INTER-UNIVERSITY Consortium for Political and Social Research, Federal Court Cases: Integrated Data Base, 1970-1995, ICPSR 8429, pts. 82, 86.

184. In doing so, we took into account the changes that have occurred over time in the AO's coding standards, and we deleted blank records. 
fiscal year 2004 and those still pending at the end of that year, which we obtained directly from the AO because they had not yet been posted on the ICPSR Web site as of the time of writing. We used our combined database to calculate the monthly volume of petitions for review (Figures 1 and 2) the monthly volume of all appeals combined and the proportion of these accounted for by petitions for review (Figure 3); the proportion of petitions for review that were reversed, vacated or remanded, and the proportion that were settled or otherwise voluntarily dismissed (Figure 6; Tables 7-10); the average amount of time that petitions for review spent on the courts' dockets (Tables 11-13); and the proportion of petitions for review filed by counsel (Figures 9-11). We also used this data in combination with data from the EOIR to estimate the proportion of BIA decisions challenged in petitions for review (Figures 5 and 11).

\section{B. Circuit Court Docket Information}

Another source of information about the federal courts is the individual court dockets. We relied on these in three ways. First, we used the Public Access to Court Electronic Records project (PACER) ${ }^{185}$ to determine whether petitions for review had been filed to challenge specific BIA decisions that we sampled. We discuss this further in Part III.E. Second, we used the Second Circuit's internal docket database to choose a random sample of petitions for review to examine in more detail. ${ }^{186}$ We discuss this further in Section III.C. Finally, we also used the Second Circuit's internal docket database to calculate the number of petitions for review filed by each lawyer practicing in the circuit. We did this by generating a list of all pending ${ }^{187}$ petitions for review as of April 21,2005, and the name of the lawyer listed as representing the petitioner in each of these. For the group of lawyers representing large numbers of petitions, we searched the list for any alternate (or erroneous) spellings of their names as well as the names of other lawyers who we knew to be working in the same law offices. We then generated a list of the twenty law offices representing the most petitions for review (Table 15). We also generated a similar list of all petitions for review filed between 1989 and 2002.

185. See http://pacer.psc.uscourts.gov (last visited May 27, 2005).

186. Throughout this study, we used the internal databases purely for statistical purposes and have relied only on information that is a matter of public record. The advantage of the internal databases over PACER was that the former allowed us to sort and analyze large quantities of data more easily.

187. We counted a petition for review as pending if the system had not recorded a mandate as having been issued. Some of the petitions in our sample were therefore already disposed of, but not yet mandated. This did not matter for our purposes, however, since we just wanted an estimate of the number of petitions each lawyer was handling. 


\section{Random Sample of Second Circuit Records}

We used a random sample of Second Circuit records to gather information about the countries of origin of aliens filing petitions for review pending on that court's docket (Appendix Table 19). ${ }^{188}$ We started by using the Second Circuit's internal databases to generate a list of all petitions for review pending on the docket as of April 12, 2005, for which the records on appeal had been filed. (There were 2043 of these.) We then filtered out petitions whose records were filed on or after January 2005 (on the assumption that some of these records might not yet have made it to the records room). From this filtered list of 1380 cases, we selected a random sample of $200 .^{189}$ We were able to locate 189 of the records on appeal for the sampled cases, and for each record we recorded the alien's country of origin. ${ }^{190}$ We assume that the eleven records we did not locate were not systematically biased in any way. $^{191}$

\section{EOIR Freedom of Information Act Response}

For more detailed information on the decisions being issued by the BIA, we made a Freedom of Information Act (FOIA) request to the EOIR for data on the total number of decisions issued each month, the number of singlemember decisions, the number of affirmances without opinion, and the number of summary dismissals. The EOIR responded by providing us with data on the number of appeals received and decided by the BIA each month from January 1975 through May 2004 in cases arising from IJ proceedings. ${ }^{192}$ We present this data starting in September 1994 (Figure 4), and we also compare it to the $\mathrm{AO}$ data in order to estimate appeal rate (Figures 5, 10, and 11). The EOIR also sent us data on the number of single-member decisions, affirmances without opinion, and summary dismissals decided each month between January 1999 and May 2004. However, the numbers listed for single-member decisions, when aggregated for fiscal year 2003, are substantially lower than the number that the EOIR reports in its 2003 statistical yearbook. ${ }^{193}$ Because we have not yet been able to determine the

188. We collected this sample as part of a separate inquiry into the extent to which petitions for review end up in the Second Circuit as a result of changes in venue at the Immigration Court level.

189. We took the sample using the "random" sampling function in SPSS 11.0.1, which uses a pseudo-random number generator and allows the user to specify a seed number.

190. We also recorded other information, such as the location of the Immigration Court in which the alien was first ordered to appear and the location of the immigration officer who issued the charging document. We have not analyzed this information here.

191. Presumably, these records had been borrowed from the records room by court staff working on these cases.

192. These numbers do not include appeals from DHS/INS District Directors.

193. The FOIA response indicates that the BIA issued 8691 single-member decisions between October 2002 and September 2003, see infra app. Table 20, while the yearbook reports 44,704 such decisions, see EOIR, Office of Planning and ANalysis, FY 2003 Statistical Year Book U1 tbl.19 (Apr. 2004) [hereinafter EOIR YB 2003], http://www.usdoj.gov/eoir/statspub/fy03syb.pdf (last visited Apr. 7, 2005). Although the FOIA data does not include decisions of DHS/INS District 
reason for this discrepancy, we have not relied on the data on summary procedures in our analysis; we have simply reported this data (Appendix Table 20).

In addition to data on BIA completions, we also asked the EOIR for data on the rates at which different types of BIA decisions were appealed, reversed, and remanded in the federal courts. However, the EOIR responded that it does not possess records relating to federal court litigation. ${ }^{194}$

\section{E. Random Samples of BIA Decisions}

In addition to relying on the above sources, we also compiled our own set of data directly from BIA decisions and courts of appeals docket sheets. We did this in three separate operations. The first was designed to test the extent to which the appeal rate was affected by the amount of time a case had spent at the administrative level, and whether the BIA had used one of its summary procedures to decide it. The second operation was designed to count the number of BIA decisions arising within each circuit for the purpose of estimating each circuit's appeal rate. The third operation was designed to estimate the composition, according to certain characteristics, of the pools of BIA decisions arising within the Second, Ninth, and Eleventh Circuits.

\section{Appeal Rate Information}

We took a representative sample from a population of BIA decisions, categorized them according to certain attributes, and then checked docket sheets to see which ones were the objects of petitions for review in the federal courts of appeals (Tables 2-4). In particular, we wanted to see whether there were statistically significant differences in the proportion of BIA decisions challenged depending on (1) the amount of time that cases had spent being adjudicated at the agency level, (2) whether the BIA had reached its decisions using a single Board member or a three-member panel, (3) whether the BIA had relied on its summary affirmance procedure, and (4) whether the BIA had relied on its summary dismissal procedure.

We started by defining the population of BIA decisions from which to take our sample. We defined the population as all BIA decisions (1) issued between May 1 and August 31, 2004; (2) where the appeals were taken directly from IJ decisions in removal proceedings; (3) where the BIA decision constituted a final order of removal; ${ }^{195}$ (4) where the respondent did

Directors, the yearbook reports that there were only 1944 such decisions in fiscal year 2003 overall, see id. at $\mathrm{T} 2$ tbl.18, so this cannot be the source of the discrepancy.

194. The response suggests that the Justice Department's Office of Immigration Litigation might have this information, but we have not pursued this further to date.

195. Our definition of "final order of removal" includes final orders granting voluntary departure, because such orders include alternate removal orders and the courts of appeals therefore treat these orders as final orders of removal for jurisdictional purposes. See, e.g., Bocova v. Gonzales, 412 F.3d $257,267-68$ (1st Cir. 2005) (The argument that an order granting voluntary departure is not a final 
not withdraw or abandon the appeal before the BIA issued its decision; and (5) where the BIA did not dismiss the petition as untimely.

We chose the first parameter because these decisions were more readily available for sampling, ${ }^{196}$ and because we were most interested in the period of time after all of the facial challenges to the affirmance without opinion procedure had been rejected. ${ }^{197}$ By looking at the population of BIA decisions issued after this had occurred, we attempted to focus on the effects of the procedural changes other than the effects of any initial surge of petitions for review aimed at challenging the new procedures themselves. ${ }^{198}$ The Fourth Circuit was the last to reject such a challenge, and it did so on March 29, 2004. ${ }^{199}$ We therefore chose May 1, 2004 as our start date, allowing a month for news of the Fourth Circuit decision to be disseminated. We chose our cutoff date of August 31, 2004, as opposed to a more recent date in order to allow a cushion of time for any petitions for review in which we were interested to have been both filed and entered on the courts of appeals' docket sheets.

The last four parameters were intended to eliminate, as much as possible, sources of variation in the proportion of challenged decisions other than the sources in which we were interested, while allowing us to keep our sample size as small as possible. Thus, in looking only at BIA decisions in appeals taken directly from IJs in removal proceedings, we excluded BIA decisions on motions to reopen or reconsider, appeals from IJ rulings on motions to reopen or reconsider, appeals taken from DHS District Directors, and appeals taken in non-removal proceedings. In looking only at BIA decisions that constituted final orders or removal, we excluded decisions that granted relief

order of removal "would require us to find that we have no jurisdiction to entertain a petition for review unless and until the petitioner has overstayed his voluntary departure deadline," and "[w]e simply do not believe that Congress contemplated such an odd result").

196. Although in theory we could have made a FOIA request for all BIA decisions ever issued (or some subset of these), we decided that the process would have been prohibitively costly and time-consuming. Instead, we relied on the EOIR's electronic database of BIA decisions. This database contains all decisions rendered after June 2004, see Update on the BIA, IMMIGR. LiTIG. Bull., Sept. 2004, at 2 (internal Department of Justice publication released pursuant to a FOIA request) (on file with authors), and appears, based on a comparison with the figures provided in response to our FOIA request, to contain most decisions rendered after December 2003. (The monthly totals after that month are higher than the figures provided in response to the FOIA request, but we attribute this discrepancy at least in part to the fact that the FOIA response did not include appeals of DHS District Directors.) As with the Second Circuit's internal databases, we have relied on the EOIR database purely for statistical purposes and have relied only on information that is a matter of public record.

197. See supra notes 156-157 and accompanying text.

198. Some EOIR officials initially speculated that the increase in the proportion of BIA decisions being appealed was at least partly a result of the facial challenges and that the numbers would.taper off once the courts of appeals rejected such challenges. See, e.g., Letter from Lori Scialabba, Chairman, BIA, to Charles Carter, Editor-in-Chief, National Law Journal (Dec. 8, 2003), available at http://www.usdoj.gov/eoir/press/03/BIANLJresponse120803.pdf. The EOIR has since reported that there has been no drop in the rate of appeal, even now that every circuit has rejected the facial challenges. See EOIR Streamlining Fact Sheet, supra note 9.

199. See Blanco de Belbruno v. Ashcroft, 362 F.3d 272, 280-83 (4th Cir. 2004). For the other circuits' rejections of these challenges, see supra note 157. 
to the respondent (either by overturning an IJ's removal order, or by affirming the relief granted by an IJ) and decisions that remanded the case to the IJ for further proceedings. ${ }^{200}$ Finally, by including only cases that were not withdrawn or abandoned before the BIA issued its decision, and by including only cases that were not dismissed as untimely by the BIA, we excluded those cases in which the respondent may have failed to exhaust administrative remedies.

All of these excluded classes of BIA decisions are likely to be challenged at different rates than our included class, and they also likely differ in their particular attributes of interest. For example, the BIA must always issue an opinion when denying a motion to reopen or reconsider, ${ }^{201}$ and such denials are likely to be appealed at a much lower rate than decisions in appeals directly from IJs. ${ }^{202}$ Similarly, when the BIA decides to overturn an IJ's removal order, it must do so with an opinion, and it is often a three-member panel that writes this opinion. Yet, the rate at which such decisions are challenged in federal court must be close to zero, given that the government cannot file petitions for review. ${ }^{203}$ Finally, in cases where the respondent

200. We also excluded decisions that merely returned the record to the IJ because the requested relief should have been requested by way of a motion to the IJ rather than an appeal to the BIA.

201. Although the regulations allow for single Board members to decide motions to reopen or reconsider decisions that they previously rendered (on their own), they do not provide for decisions on these motions without opinion. See 8 C.F.R. $\S 1003.1$ (e)(5) (2005).

202. This is because the courts of appeals generally review denials of motions to reopen or reconsider only for abuse of discretion, see, e.g., Ke Zhen Zhou v. U.S. Dep't of Justice, 265 F.3d 83, 93 (2d Cir. 2001); Oh v. Gonzales, 406 F.3d 611, 612 (9th Cir. 2005), while conducting a more thorough review of the underlying BIA decisions rendered in appeals directly from IJs, see, e.g., Khouzam v. Ashcroft, 361 F.3d 161, 165 (2d Cir. 2004). While it is possible to file a petition for review for both the denial of a motion to reopen or reconsider and the underlying BIA decision, each petition must be filed separately in a timely manner, and the petition of the underlying decision is the one that is usually more likely to result in relief. Therefore, people will often file a petition for review of the underlying BIA decision, but not bother to file a petition from the subsequent denial of the motion to reopen or reconsider. See, e.g., id. at 167.

203. See EOIR Streamlining Fact Sheet, supra note 9. Although there does not appear to be an express statutory prohibition against the government filing a petition for review, it is a commonly accepted proposition that this cannot occur. When the INS was still in existence, it could refer BIA decisions it disagreed with to the Attorney General, but if the Attorney General ruled against it, the INS would be forced to acquiesce because the Attorney General had direct authority over the INS. See Martin, supra note 54, at 615-16. In addition, had the INS tried to challenge a BIA decision through a petition for review without referring it to the Attorney General, it would have nonetheless been required, under INA $\S 242$ (b)(3), 8 U.S.C. $\S 1252$ (b)(3) (2000), to name the Attorney General as respondent, and, therefore, would still have been in a bureaucratically impossible situation. Now that the INS's functions have been transferred out of the Department of Justice and to DHS, it might be theoretically possible, under the statute, for DHS to challenge an Attorney General or BIA decision in court, but this would be problematic from a number of perspectives, see Martin, supra note 54, at 615-16, not least of which is the fact that the statute makes the Attorney General's determinations and rulings on all questions of immigration law controlling over the Secretary of Homeland Security, see 8 U.S.C. $\$ 1103(\mathrm{a})(1)(2005)$.

We say the appeal rate for BIA decisions overturning removal orders must be "close to zero" because there may be situations in which the BIA overturns a removal order but does not grant the respondent all of the relief sought. For instance, the BIA may grant withholding or CAT relief but deny asylum. In such cases, we have found instances of aliens filing petitions for review, and these petitions being adjudicated on the merits even though-as far as we can tell-they do not actually challenge final orders of removal. See Kalubi v. Ashcroft, 364 F.3d 1134 (9th Cir. 2004). We have also 
withdraws or abandons an appeal to the BIA, or where the appeal was untimely, the BIA appears to always issue a short explanatory opinion, which is very unlikely to be challenged in the federal courts. ${ }^{204}$ Including any of these different classes of BIA decisions in our population without accounting for them in our analysis could have skewed our results. Yet, accounting for such classes in our analysis would have required us to increase our sample size to maintain our desired level of statistical power. ${ }^{205}$ We therefore excluded these classes and focused our efforts instead on the one class of BIA decisions that we thought would be most interesting and telling.

Having defined our population, we next chose a sample size and sampling method. We settled on a sample size of 428 BIA decisions, as a compromise between the level of statistical power we wanted and the amount of time it would take to categorize these decisions and determine which ones were challenged in the courts of appeals. ${ }^{206}$ We tailored our sampling method to our ability to select and sort BIA decisions that fell within our population parameters. Only the first two parameters could be selected without reading the BIA decisions themselves; these parameters were included in the EOIR's database and could therefore be selected easily. ${ }^{207}$ Based on a pilot sample, ${ }^{208}$ we estimated that of the pool of BIA decisions that fell within the first two

found instances of such cases being dismissed for lack of jurisdiction, without prejudice to the alien filing a petition for review if and when a final order of removal is ever issued. See Zhao Qin Zeng v. INS, No. 02-72531, 2003 WL 22977463 (9th Cir. 2003).

204. If a petition for review were filed from such an opinion, it would likely be dismissed for lack of jurisdiction due to a failure to exhaust administrative remedies. See 8 U.S.C. $\$ 1252$ (d)(1) (2000); $c f$. Theodoropoulos v. INS, 358 F.3d 162, 174 (2d Cir. 2004) (holding that district court lacked jurisdiction over habeas corpus petition because petitioner had waived his right to appeal the IJ's decision to the BIA, and had therefore failed to exhaust administrative remedies); see generally Gill v. INS, 420 F.3d 82 (2d Cir. 2005) (summarizing Second Circuit's exhaustion requirements).

205. "Power" refers to the probability that a given test will reject the null hypothesis if that hypothesis is in fact false. See GEORge W. SNEDECOR \& William G. Cochran, Statistical METHOds 68-69 (8th ed. 1989).

206. We estimated that 428 BIA decisions would give us an $80 \%$ chance of detecting a statistically significant difference in appeal rate between two categories of BIA decisions if such a difference existed, assuming that the appeal rates were 0.24 and 0.37 for the first and second categories, respectively, and assuming that the ratio of decisions in the first category to decisions in the second category was 0.75. See Joseph L. Fleiss, Statistical Methods for Rates and PROPORTIONS 38-49 (2d ed. 1981). Our assumptions were based on a pilot analysis in which we sampled and categorized 363 BIA decisions in cases appealed directly from IJs. The assumptions were estimates of the appeal rates of affirmances with opinion and affirmances without opinion, and the ratio of these two categories within our sample. From the pilot analysis, we quickly discovered that the number of three-member decisions and the number of summary dismissals were so small as to make it unlikely that we would be able to obtain any statistically significant results for these categories without sampling thousands of cases.

207. The database makes it possible to select cases based on, among other things, date range and type of BIA decision. To satisfy our second parameter, we selected the database's "Case Appeal" category in the field for type of decision. We assume that this category accurately reflects our second parameter, given that it excludes all the other categories, which are: "Appeal or Motion to Set Aside," "Appeal of IJ MTR" (which we assume to be appeals of IJ decisions on motions to reopen or reconsider), "Bond Appeal," "Circuit Court Remand," "DD 212," "DD Bond," "DD Fines," "DD Visa" (the previous four of which we assume to be appeals from DHS District Directors), "Interlocutory Appeal," "MTR BIA" (which we assume to be BIA decisions on motions to reopen or reconsider), "Reasonable Cause Appeal," "Special Circumstances Appeal," and "Zero Bond Appeal."

208. See supra note 206. 
parameters, $78 \%$ would fall within the remaining parameters. We therefore took a random sample of 548 BIA decisions from the pool of all BIA decisions that fell within the first two parameters. ${ }^{209}$ Throughout this process, we counted and sorted BIA decisions by individual respondent. In other words, where the claims of multiple respondents were adjudicated in one BIA decision, this decision was listed multiple times in our population (once for each respondent) and could have conceivably been selected multiple times in our random sample.

For each decision in our random sample, we first recorded the additional information necessary to decide whether the decision fell within our population parameters (i.e., whether the decision constituted a final order of removal, whether the appeal was abandoned or withdrawn before the BIA issued its decision, and whether the BIA dismissed the appeal as untimely). If the decision fell within our population, we then recorded the other information we were interested in studying (i.e., whether or not the BIA decision was made by a single member (as opposed to a three-member panel); whether or not the BIA decision was an affirmance without opinion (as opposed to containing some opinion, regardless of how long); whether or not the BIA decision was a summary dismissal (defined as those cases in which the BIA expressly stated that it was using the summary dismissal procedure provided for in the streamlining regulation); the length of time between the commencement of removal proceedings and the BIA's decision (measured as number of days between the "Notice to Appear" date listed in the EOIR's database and the BIA's decision date); whether or not a petition for review was filed in the federal court of appeals; and the date on which any such petition was filed).

All but the last of these pieces of information were obtained by looking at the BIA and IJ decisions themselves, or in the case of the time question by performing a calculation using the dates listed in the EOIR's database. To determine whether a petition for review was filed, we searched the docket of the court of appeals that would have had jurisdiction, based on the location in which the IJ completed proceedings. ${ }^{210}$ We searched based on the name of

\footnotetext{
209. As with our sample of Second Circuit records, we took this sample using the "random" sampling function in SPSS 11.0.1, see supra note 189. We started with a table of all 11,296 BIA decisions in the "Case Appeal" category issued between May 1 and Aug. 31, 2004, sorted by A-number and BIA decision-date. (We obtained this information from the EOIR database on Oct. 12, 2004.) We then took a "random" sample of exactly 548 cases out of this total, using a "seed" number of 200 as the starting point for SPSS's pseudo-random number generator. Because the selection process was pseudo-random-i.e. relying on deterministic chaos as opposed to truly random eventsand because we specified the "seed" number, it is possible to replicate our sample exactly. This allowed us to incorporate the information we gathered in our pilot sample into the final sample. We selected the pilot sample using the same population of cases sorted the same way and the same seed number, so our final sample contained all of the cases in our pilot sample.

210. See 8 U.S.C. § 1252(b)(2) (2000) (permanent rules); IIRIRA § 309(b)(4)(D), 8 U.S.C. $\$ 1101$ (2000) (transitional rules). To determine where the IJ completed proceedings, we looked first to the IJ location given at the top of the BIA decision, and where possible, cross-checked this with the location given on the IJ decision itself. By limiting our searches to just the court with jurisdiction, we ended up excluding any petitions that were filed in the wrong circuit and not yet transferred to the
} 
the respondent listed on the BIA and IJ decisions, using all possible combinations of any two-word family names, and using the names of all family members listed on the decision. Where a decision listed multiple family members, we often found the petition for review was filed under the name of a family member not included in our sample. (As explained above, BIA decisions with multiple respondents were counted once for each respondent in our population, so in most cases our sample contained only one of the respondents listed on the decision.) In these cases, we only counted the petition for review as having been filed if we could also ascertain from the docket sheet that the family member in our sample was included as a party in the petition for review. In all cases, once we found a petition for review with the correct name associated with it, we then verified that it was in fact the same person by cross-checking the alien registration number (" $A$ " number) ${ }^{211}$ from the BIA decision on the court of appeals docket sheet.

It should be noted that the appeal rates we estimated using this method are qualitatively different from the appeal rates we estimated by comparing the AO data on monthly petitions for review with the EOIR's response to our FOIA request on monthly BIA decisions. The former estimates link sampled BIA decisions with petitions for review of those particular decisions, they limit the BIA decisions used in the denominators of the rate calculations according to the parameters discussed above, and they use the sample rate calculations to estimate the population appeal rates. In contrast, the $\mathrm{AO} /$ EOIR appeal rate estimates do not link individual BIA decisions with petitions for review, but instead divide the total number of petitions for review filed in a given period by the total number of BIA decisions issued during a comparable period. These estimates also look at all BIA decisions issued in appeals from $\mathbf{I J}$ proceedings, without further limitations, and instead of using a sample calculation to estimate information about the population, these estimates look directly at the entire population. (They remain estimates, however, as opposed to exact calculations of the entire populations' appeal rates, because they do not directly link each BIA decision with a petition for review, and the thirty-day window for filing petitions for review makes it impossible to calculate exactly how many of the BIA decisions issued in any given period were appealed. $)^{212}$

correct circuit by the time we ran the searches (November 2004). We assume, however, that the number of such petitions is negligible and does not affect our results.

In all cases, we performed the docket searches electronically. For the courts of appeals in every circuit but the Second and Seventh, we ran the searches on the websites of the Public Access to Court Electronic Records project (PACER). For the Second Circuit, we ran the searches on the court's internal database because the PACER site was not working properly at the time. For the Seventh Circuit, which does not have a PACER website, we used the docket search menu on the court's official website.

211. The " $A$ " number is the main key by which immigration files are organized at the agency level. See ILP, supra note 32, \& 3.24[3][a].

212. The AO/EOIR appeal rate estimates are discussed further in Part IV.C. 


\section{Number of BIA Decisions Arising Within Each Circuit}

We counted the number of BIA decisions arising within each circuit by starting with the list of all BIA decisions in the "Case Appeal" category issued between May 1 and August 31, 2004, ${ }^{213}$ and then coding each of these decisions according to circuit. We did the coding based on the database field "Base City," which indicates the location of the immigration court that completed proceedings. After categorizing the decisions, we simply counted them, using Excel Pivot Tables. We used this information, in conjunction with the AO data to estimate the appeal rate for BIA decisions in each circuit (Table 1).

\section{Composition of Pools of BIA Decisions}

We took samples of the pools of BIA decisions arising within the Second, Ninth, and Eleventh Circuits as follows. We started with a list of all BIA decisions in the "Case Appeal" category issued between May 1 and August $31,2004 .{ }^{214}$ We then used the immigration court locations listed with these decisions to categorize the decisions according to the circuit that would have had jurisdiction over any petition for review. We created lists of all decisions arising in the Second, Ninth, and Eleventh Circuits, and we took a random sample of 100 decisions from each list. ${ }^{215}$ We then reviewed each decision in the samples, looking at the BIA decision and, where available, the IJ decision, to determine (1) the alien's country of origin, (2) whether the alien sought persecution-based relief, and (3) whether the BIA decision left the alien with a final order of removal (including an alternate final order of removal accompanying a grant of voluntary departure). If country of origin was disputed, we relied, where possible, on the IJ's findings on this issue or the country to which the IJ ordered the alien expelled. In a number of cases, information was simply not available, and we recorded fields as "unknown." We present this data in the Appendix (Tables 16-18).

\section{F. Litigants}

Since we want to know why more people are filing petitions for review, the most obvious step would be simply to ask them. We tried to do this on a large

213. The list contains 11,296 decisions. See supra note 209 .

214. We generated this list from the EOIR data based on Oct. 12, 2004. The list contains 11,296 decisions. See supra note 209.

215. There were a total of 2230 decisions arising within the Second Circuit, 4280 within the Ninth Circuit, and 1995 within the Eleventh Circuit. As with our appeal rate sample, we took the random samples using SPSS's "random" number generator. See supra note 209. For each of these samples, however, we set the pseudo-random "seed" number to fifty. (In this case, we did not rely on the "seed" number to incorporate any pilot sample, but we report it here so that anyone who wishes to can recreate our samples in order to check them.) 
scale by sending out a survey using various immigration email lists, ${ }^{216}$ but we received only five responses. We have therefore relied on the responses we did receive as purely anecdotal evidence. We are very thankful to those attorneys who did respond as well as to those who spoke with us informally throughout our research, and we will keep the responses on file in case they can be used in the future.

\section{G. Limitations of the Data}

One final note that we should include regarding our data is that they are obviously subject to a number of limitations. First, they represent only a miniscule proportion of the information that would be needed to provide a truly complete picture of the immigration surge and a full analysis of its causes. Second, they are subject to error at a number of stages, from collection to processing. While we have done our best to minimize this error, we have not undertaken any analysis of the degree to which it may exist, particularly in the reporting and collection phases. ${ }^{217}$

\section{TRacking the SURGE}

Our data help to shed light on the surge in petitions for review of BIA decisions in two ways. First, they provide us with a better picture of the surge itself, and second, they help us to explain why the surge has occurred. We start by presenting the picture of the surge itself. Although the magnitude and timing of the surge have already been well documented elsewhere, the AO data series expands our horizon and adds more detail, allowing us to track the monthly volume of petitions for review since 1971 . By comparing this with the data released by the EOIR in response to our FOIA request, we estimated the proportion of BIA decisions challenged per month since November 1997-what we term the rate of appeal. Our estimates show that the surge is accounted for not just by an increase in the BIA's output, but also by an increase in the rate of appeal.

\section{A. Volume of Petitions for Review}

Looking at monthly filings in all of the U.S. Courts of Appeals combined, the surge becomes immediately apparent. As Figure 1 shows, petitions for review were relatively infrequent throughout the 1970s and 1980s. During

216. The survey asked lawyers and firms to describe the changes in their workload of immigration cases in the courts of appeals over the past ten years, and to offer explanations for any such changes.

217. Cf. Eisenberg \& Schlanger, supra note 182; Stephen R. Couch, Quantitative Immigration Data, Scientific Knowledge, and Public Policy: Possibilities, Limitations, and Interrelationships, in Quantitative Data and Immigration Research 259, 266-67 (Stephen R. Couch \& Roy Simón Bryce-Laporte eds., 1979) (noting the problems associated with using governmental data that has not been collected for research purposes, particularly in the immigration context). 
the first half of the 1980s, the average was thirty-three petitions per month. There was a noticeable drop at the end of 1986, and the monthly volume remained low for the rest of that decade, averaging about nineteen petitions per month. This probably resulted from the large-scale legalization of undocumented aliens under the Immigration Reform and Control Act. ${ }^{218}$

In the beginning of the 1990s there was clearly an upward trend, and the volume soon surpassed that of the early 1980s. There was a spike in April 1997, and then another one in July 1999, but also a leveling-off during the latter part of the decade, with the volume for most months remaining below $200 .^{219}$ We discuss each of the spikes further below.

The big change comes after March 2002. Between March and May 2002, the monthly volume of petitions for review rose from 270 to 711 . In January 2003, that number topped 900, and in April 2004 it topped 1100. While the number decreased for a few months after that, there is no sign to date that it is on its way back to pre-2002 levels. ${ }^{220}$ As another measure of the magnitude of the surge, we compared the total number of petitions for review filed in the courts of appeals during the thirty-month periods before and after April 1, 2002. From October 1999 through March 2002 there were a total of 4407 such petitions; from April 2002 through September 2004 there were 23,069more than five times as many. Similarly, the average monthly volume in the thirty-month period before April 1, 2002, was 146.90, with a standard deviation of 34.36 , while the average monthly volume in the following thirty-month period was 768.97 , with a standard deviation of $174.03 .^{221}$

It has already been reported that the Second and Ninth Circuits receive the highest volume of petitions for review, and this is confirmed by our data as well. Figure 2 shows that while there have been noticeable increases in

218. Pub. L. No. 99-603, $§ 201,100$ Stat. 3359, 3394 (1986); see LEGOMSKY, supra note 28, at 607-10; Nancy Rytina, IRCA Legalization Effects: Lawful Permanent Residence and Naturalization Through 2001, at 3 (Oct. 25, 2002) (paper presented at The Effects of Immigrant Legalization Programs on the United States: Scientific evidence on immigrant adaptation and impacts on U.S. economy and society, The Cloister, Mary Woodward Lasker Center, NIH Main Campus) (reporting that the IRCA program ultimately allowed almost 2.7 million undocumented aliens to adjust to lawful permanent resident status), available at http://uscis.gov/graphics/shared/statistics/publications/ irca0114int.pdf (last visited June 4, 2005). Although applications for adjustment under the IRCA's general legalization program were accepted starting in May 1987, see ALEINIKOFF ET AL., supra note 21 , at 1152 , the passage of the Act in November 1986 presumably caused an immediate reduction in the number of petitions for review simply by creating the prospect of future adjustment.

219. For more on the April 1997 spike, see infra notes 223-229 and accompanying text.

220. We base this assertion on the number of petitions for review that continue to be filed in the Second Circuit at the time of writing.

221. Our choice of April 1,2002, as the dividing line is based on the fact that this is clearly near the beginning of the large increase in petitions for review, and it follows the BIA's March 15, 2002, expansion of streamlining, see supra note 144 and accompanying text, factoring in some lag time for people to actually file their petitions. By doing this, we are obviously prejudging the conclusion that the increase corresponds with the streamlining expansion. For a more precise look at the effect of the streamlining expansion, one could conduct an interrupted time series analysis. Cf., e.g., Brian J. Ostrom, Roger A. Hanson \& Fred L. Cheesman II, Congress, Courts and Corrections: An Empirical Perspective on the Prison Litigation Reform Act, 78 Notre Dame L. Rev. 1525, 1541-58 (2003). We have not done that here. 
monthly filings since March 2002 in the Third, Fifth, Sixth, Seventh, and Eleventh Circuits, none of these courts receive anywhere near as many petitions for review as the Ninth and Second Circuits. ${ }^{222}$ Monthly filings in the Ninth Circuit have hit 604, with the mean from April 2002 through September 2004 lying at 389.33; in the Second Circuit, the maximum lies at 278 , with a mean of 171.47 for the same period.

Another interesting thing we see in the circuit-by-circuit breakdown is that the Eleventh and Second Circuits each encountered short-lived spikes in their monthly filings prior to 2002. We already saw a spike around April 1997 in the nationwide data presented in Figure 1. What we see from Figure 2 is that this spike was actually localized to the Eleventh Circuit. A closer look at the Eleventh Circuit's docket information suggests that the spike was caused by people (1) rushing to apply for suspension of deportation before this form of relief was replaced by the IIRIRA, and (2) challenging the IIRIRA's stoptime rule for calculating the period of continuous physical presence on which eligibility for both suspension of deportation and cancellation of removal hinge. ${ }^{223}$ The stop-time rule made hundreds of thousands of aliens ineligible for relief. ${ }^{224}$ This was the case, however, only because the BIA interpreted the rule broadly in Matter of N-J-B-, issued on February 20, $1997 . .^{225}$ The interpretation particularly affected 20,000 to 50,000 Nicaraguans, Salvadorans, and Guatemalans living in Florida, ${ }^{226}$ many of whom appear to have filed the petitions for review that account for the spike seen in Figure $2 .^{227}$

222. There are practically no petitions for review filed in the District of Columbia Circuit because there are no Immigration Courts within its jurisdiction. See supra note 109 and accompanying text. There are, nonetheless, a small number that are filed in spite of the lack of jurisdiction and are quickly dismissed or transferred. See, e.g., Hadera v. INS, 136 F.3d 1338 (D.C. Cir. 1998). Even before Oct. 31,1996 , when petitions for review could be filed in the Circuit in which the alien resided, the Administrative Office data show that there were few petitions-no more than ten per year-filed in the District of Columbia Circuit.

223. The stop-time rule was created by IIRIRA, Pub. L. No. 104-208, § 304(a), 110 Stat. 3009 (adding INA \& 240 (d)(1), 8 U.S.C. \& $1229 \mathrm{~b}(\mathrm{~d})(1)(2000)$ ). There was initially some uncertainty over the scope of the new rule, because it referred specifically to aliens served with a "notice to appear under [IIRIRA] section 239(a)," and was supposed to apply to "notices to appear issued before, on, or after" the date of IIRIRA's enactment. Id. \$\$ 304(a), 309(a)(5). The "notice to appear" was the charging document used to initiate the "removal proceedings" that the IIRIRA created for the first time in section 239(a) to replace deportation and exclusion proceedings. Before IIRIRA's enactment, there were no "notices to appear," and INA section 239 dealt with an entirely different topic. See INA $\S 239$, Pub. L. No. 82-414, 66 Stat. 163, 203 (1952); 8 U.S.C.A. \$ 1229 (West 1997). It was therefore an open question at first whether the rule was triggered by the pre-IIRIRA charging documents. The BIA answered this question in the affirmative in In re N-J-B-, 21 1. \& N. Dec. 812 (BIA 1997), making aliens served with charging documents before IIRIRA ineligible for relief. See generally Stanley Mailman \& Stephen Yale-Loehr, Amnesty for Central Americans?, 2 Bender's ImMigr. Bull. 734 (1997).

224. See Mailman \& Yale-Loehr, supra note 223; Mabell Dieppa, Immigrants Get Reprieve from Deportation Threat, Miami Herald, Apr. 24, 1997, at 2B.

225. 21 I. \& N. Dec. 812.

226. See Mailman \& Yale-Loehr, supra note 223; Dieppa, supra note 224.

227. “N. J. B." herself filed a petition for review filed in the Eleventh Circuit on Mar. 19, 1997, N.J.B. v. Reno, No. 97-4400, and our data indicate that over 100 other aliens filed petitions for review in the Eleventh Circuit in March, April, and May of that year, most of them presumably raising the same issue. In addition to the petitions for review, there was also a class-action suit, which resulted in 
FIGURE 1. MONTHLY PETITIONS FOR REVIEW OF BIA DECISIONS NATIONWIDE
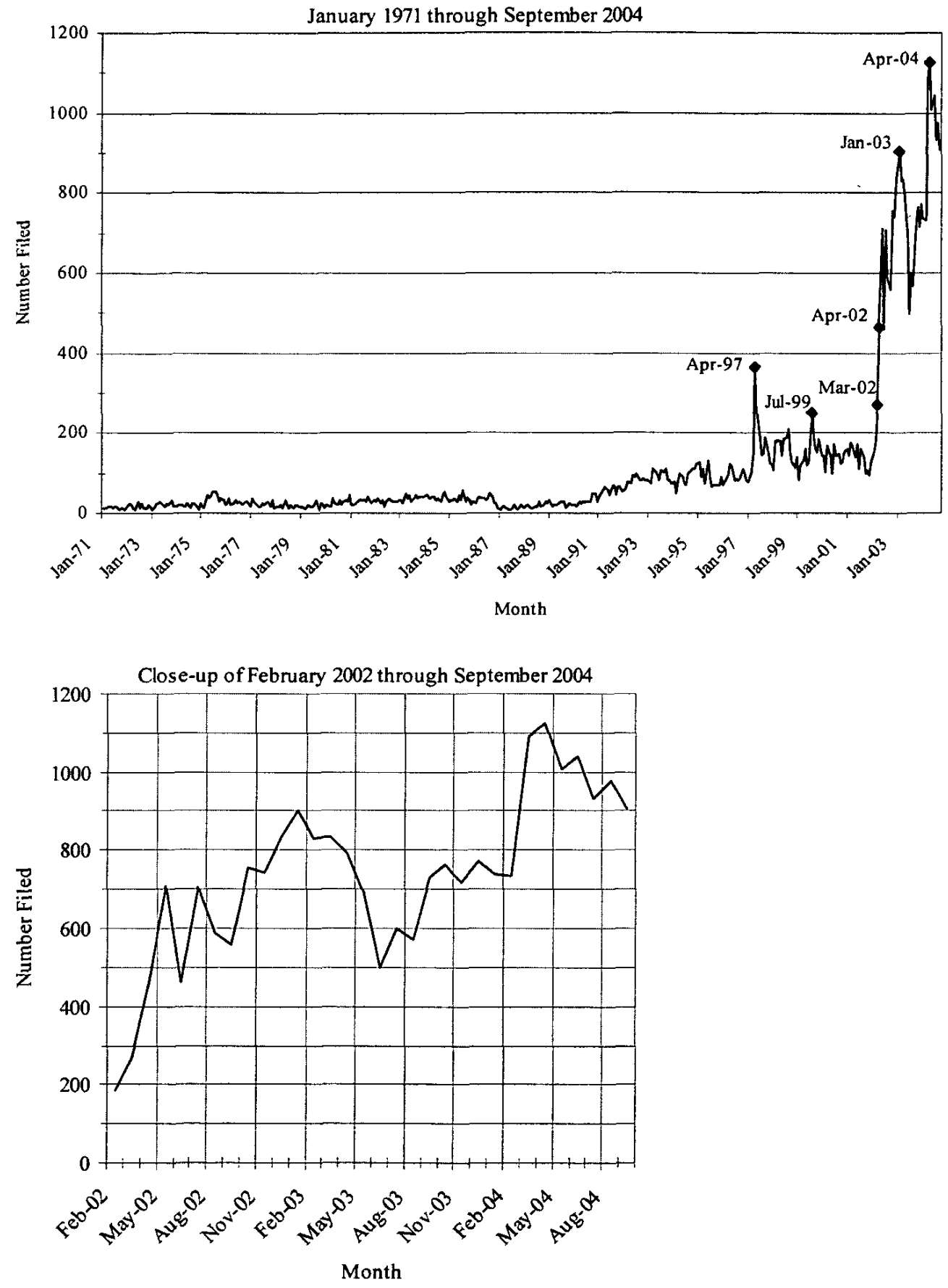

Source: Administrative Office data, see supra Part III.A.

a far-reaching temporary restraining order and preliminary injunction. Tefel v. Reno, $972 \mathrm{~F}$. Supp. 608 (S.D. Fla. 1997); Tefel v. Reno, 972 F. Supp. 623 (S.D. Fla. 1997), vacated by 180 F.3d 1286 (11 th Cir. 1999). 
The spike was short-lived, presumably because the BIA decided a chunk of pending cases based on $N-J-B$ - all at once, and the effected aliens had only thirty days to file petitions for review if they wanted to challenge these decisions. In any event, the Attorney General vacated $N-J-B$ - on July 11 , $1997,{ }^{228}$ and the Eleventh Circuit ultimately remanded most of these petitions to the BIA. ${ }^{229}$

The Second Circuit's pre-2002 spike is a different story. It occurred in July 1999, and it has more to do with the way the statistics were reported than an actual surge in filings. The spike was caused by a group of cases that had been filed on earlier dates but withdrawn without prejudice to reactivation pending the Second Circuit's decision in Henderson v. INS. ${ }^{230}$ Henderson dealt with the jurisdictional provisions of the IIRIRA and the retroactive application of section 440(d) of the AEDPA. It was decided on September 18, 1998, but the court did not issue the final mandate until June 17, 1999. ${ }^{231}$ Most of the cases that had been withdrawn were then reactivated in July of that year. ${ }^{232}$ These reactivations were then counted for statistical purposes as if they had been July 1999 filings. $^{233}$

As a measure of the degree to which the surge has had an impact on the courts of appeals, Figure 3 shows the proportion of total monthly filings accounted for by petitions for review. For all circuits combined, the mean for the eighteen-month period from April 2002 through September 2003 was $13.54 \%$ (with a standard deviation of $2.65 \%$ ), as compared to $3.20 \%$ (with a standard deviation of $0.90 \%$ ) in the eighteen-month period from October

228. See Federal and Administrative Decisions, 2 BENDER's IMMIGR. BULL. 630 (1997); Carol Rosenberg, A Break for Central Americans: Reno Moves to Freeze Massive Deportations, MiamI HERALD, July 11,1997 , at 1 A.

229. After the Attorney General vacated $N \cdot J-B-$, the Eleventh Circuit dismissed the petition for review from that decision as moot. See Federal and Administrative Decisions, supra note 228 . It then ordered "the parties in all [related cases] ... to show cause [within ten days] why those cases should not also be dismissed for lack of jurisdiction." Id. Our Administrative Office data show that most of the cases filed in the Eleventh Circuit in April 1997 were remanded to the BIA in September 1997 (or at least they were coded for statistical purposes as having been disposed of that way).

230. 157 F.3d 106 (2d Cir. 1998).

231. According to the docket sheet, a mandate initially issued on Mar. 18, 1999, but it was recalled pending a decision on a motion for en banc rehearing in a related case.

232. After reactivation, some of the parties then stipulated to dismissals with prejudice and returned to the BIA for new decisions in light of Henderson, 157 F.3d 106. See, e.g., PereyraMartinez v. INS, No. 97-4051 (2d Cir. Aug. 10, 1999) (stipulation and order dismissing petition with prejudice, vacating the BIA decision, and remanding to the BIA). Other parties pressed on with litigation and were ultimately heard by the Second Circuit. See, e.g., Calcano-Martinez v. INS, 232 F.3d 328 (2d Cir. 2000).

233. In the Administrative Office data set, the cases are tagged with a code that translates to "reinstated after previously being reported as dismissed due to procedural default." INTER-UNIVERSITY Consortium for Political and Social Research, Federal Court Cases: Integrated Data Base, 1970-2000: APPELLATE TERMINATIONS, 1998 ICPSR 8429 (2001), available at http:/www.icpsr.u$\mathrm{mich} . \mathrm{edu} / \mathrm{cgi}$-bin/bob/file $? \mathrm{comp}=$ none $\&$ study $=8429 \& \mathrm{ds}=119 \& \mathrm{dsfmt}=\mathrm{LREC} \&$ filetype $=$ CBPD (last visited Oct. 18, 2005), (field description for "REOPEN," code "4"). Their original filing dates are not listed, so the only way to count them at all (without going back to the docket sheet for each case), is to count them according to the dates on which they were reactivated. That is what we have done here. We note that apart from the July 1999, only a very small number of petitions for review are tagged with this code, so we assume that this phenomenon has not skewed our results. 
FIGURE 2. MONTHLY PETITIONS FOR REVIEW OF BIA DECISIONS By CIRCUIT
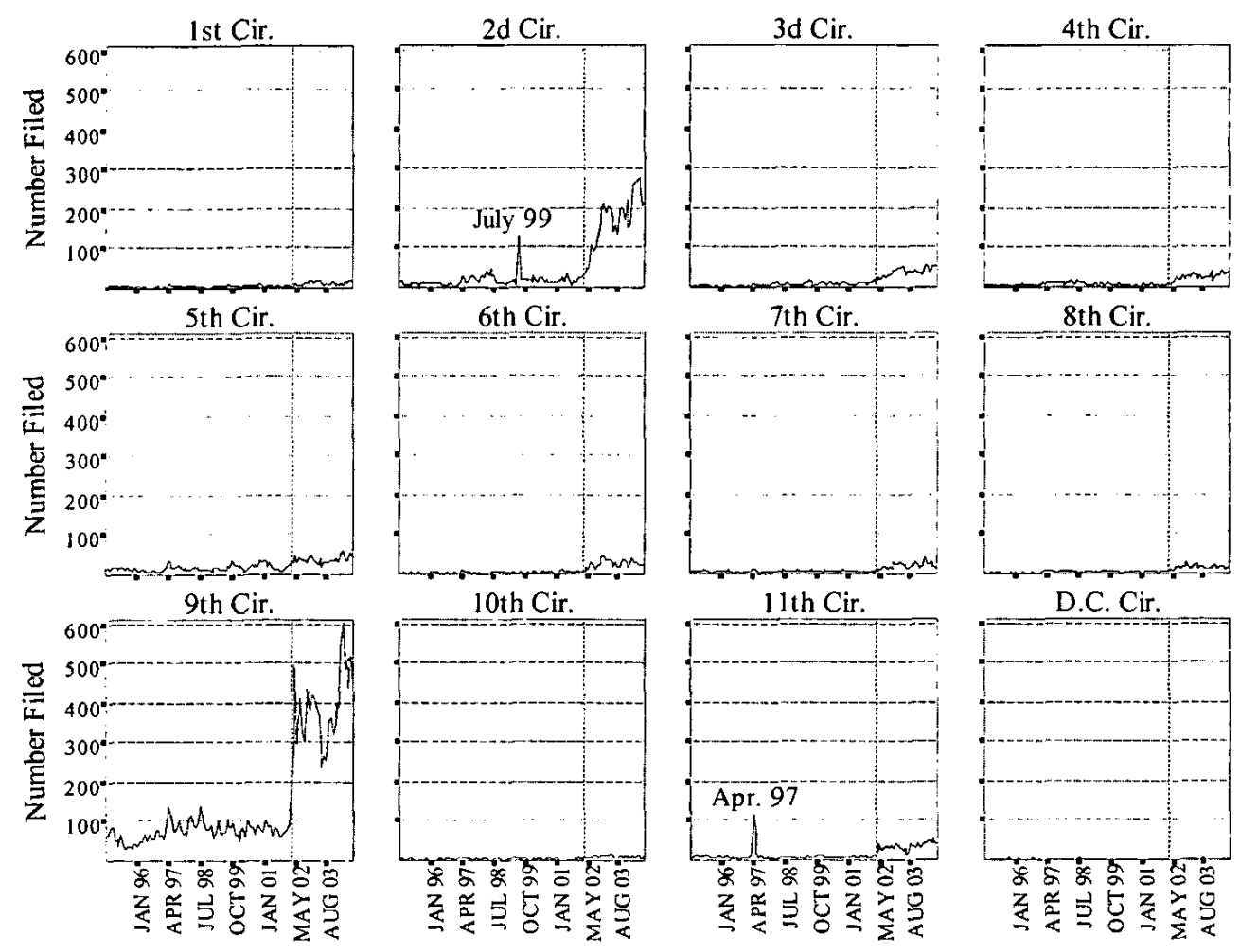

Month

Month

Month

Month

Source: Administrative Office data, see supra Part III.A.

Note: The vertical line on each chart marks the position of March 2002.

2000 through March 2002. In the Ninth Circuit, the mean for the eighteenmonth period from April 2002 through September 2003 was 32.63\% (with a standard deviation of $5.05 \%$ ), as compared to $9.67 \%$ (with a standard deviation of $2.66 \%$ ) in the eighteen-month period from October 2000 through March 2002. Finally, in the Second Circuit, the mean for the eighteen-month period from April 2002 through September 2003 was $27.27 \%$ (with a standard deviation of $9.38 \%$ ), as compared to $4.04 \%$ (with a standard deviation of $1.76 \%$ ) in the eighteen-month period from October 2000 through March 2002.

\section{B. Volume of BIA Decisions}

The surge can be accounted for in part by the BIA's increased output. Figure 4 shows the monthly volume of BIA decisions between September 1994 and May 2004 in appeals arising from IJ decisions (meaning all BIA decisions except those arising from the decisions of District Directors). We notice large but short-lived spikes in June 1998 and June 2001 and then a more sustained increase starting in March 2002. The June 1998 spike is 
FIGURE 3. PROPORTION OF TOTAL MONTHLY CASELOAD ACCOUNTED FOR BY PETITIONS FOR REVIEW

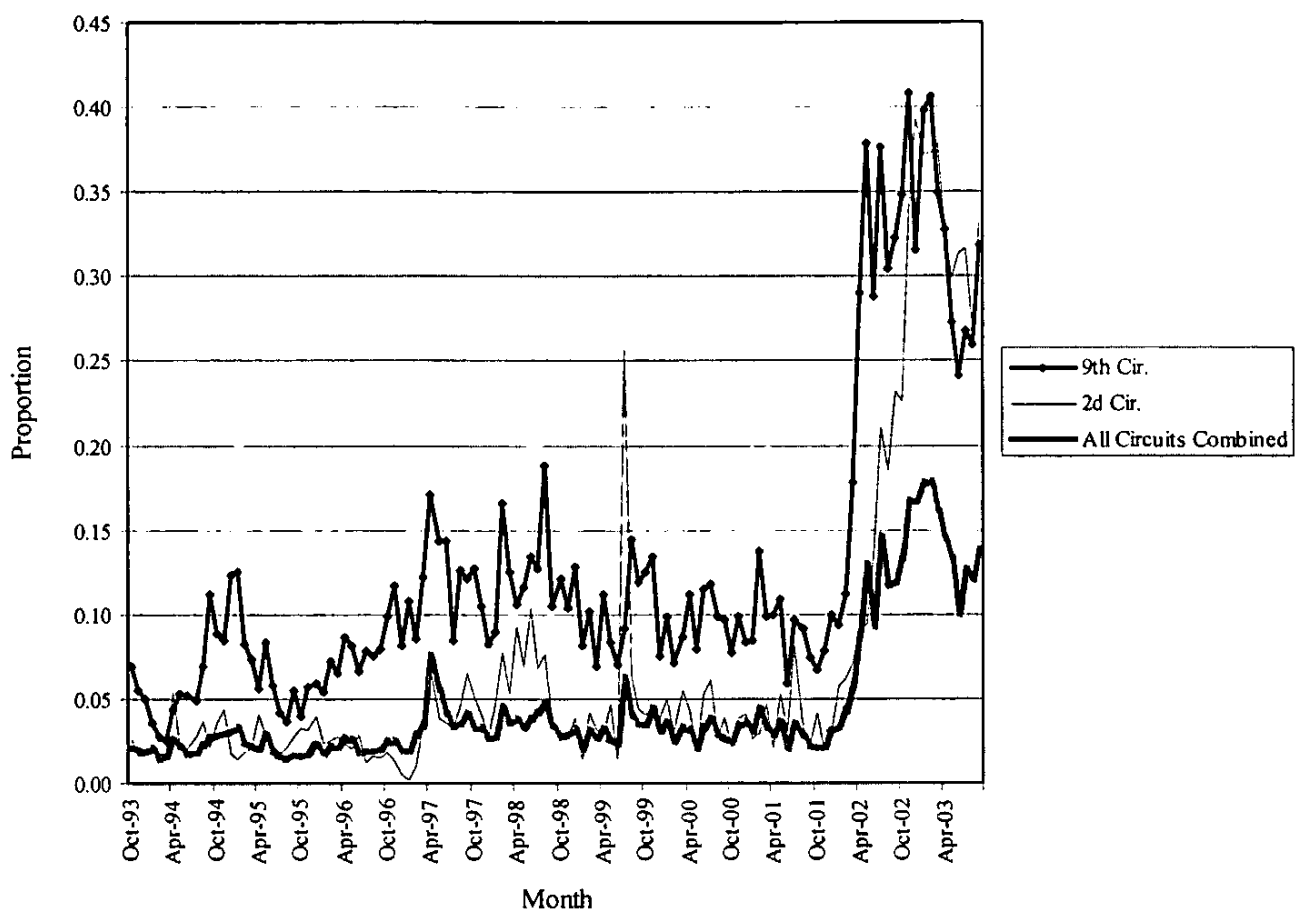

Source: Administrative Office data, see supra Part III.A.

probably accounted for by some 5000 routine cases that the BIA remanded as a result of the Nicaraguan Adjustment and Central American Relief Act. ${ }^{234}$ The June 2001 spike is probably accounted for, at least in part, by the BIA's resolution of hundreds of appeals that had been on "hold" status pending the Supreme Court's decision in INS v. St. Cyr. ${ }^{235}$ The increase in March 2002, on the other hand, suggests a more fundamental shift in dynamics. For instance, if we compare the twenty-seven month periods before and after March 1, 2002, we find that the BIA's output has more than doubled, from 53,546 decisions to 110,548 decisions. $^{236}$ The mean number of decisions per

234. Pub. L. No. 105-100, Title II, § 201-204, 111 Stat. 2130 (1997). This is discussed in the supplemental material accompanying the BIA's 1999 streamlining regulation, Executive Office for Immigration Review; Board of Immigration Appeals: Streamlining Regulation, 64 Fed. Reg. 56,135, 56,139 (Oct. 18, 1999).

235. 533 U.S. 289 (2001). This is discussed in BIA Chairman Lori Scialabba's Dec. 22, 2003, public letter to the American Bar Association, available at http://www.usdoj.gov/eoir/press/03/ ABA.pdf.

236. We have chosen to look at twenty-seven month periods because that is the size of the period for which we have data after Mar. 1, 2002. We use Mar. 1, 2002, as the dividing line because this is clearly near the beginning of the large increase in BIA decisions, and it keeps together all of the BIA decisions issued after the Mar. 15, 2002, expansion of streamlining. See supra note 144 and accompanying text. Since we are looking directly at the BIA's output here, we did not factor in the lag-time that led us to use Apr. 1, 2002, for our analysis of petitions for review. Cf. supra note 221. 
FIGURE 4. MONTHL Y BIA DECISIONS IN APPEALS FROM IJ PROCEEDINGS

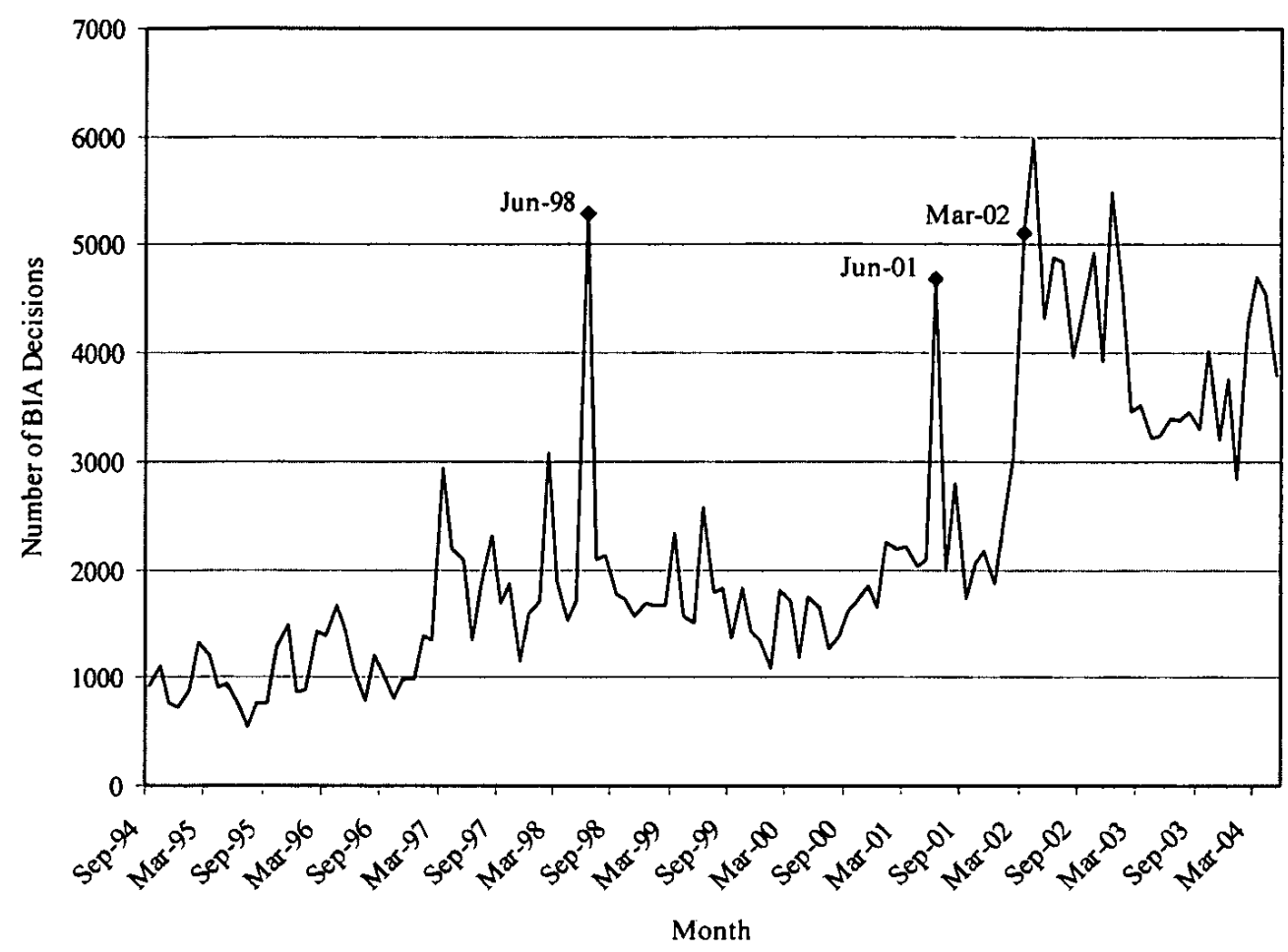

Source; EOIR response to authors' FOIA request, see supra Part III.D.

Note: The numbers are reported by the EOIR as BIA "Appeals Decided," excluding "appeals of the decisions of DHS District Directors." The numbers presumably include all decisions in appeals arising from IJ decisions, such as appeals from the decisions of IJs in removal, exclusion and deportation proceedings; appeals from IJ decisions on motions to reopen; motions to reopen cases already decided by the BIA; appeals pertaining to bond, parole, or detention; and interlocutory appeals from IJ proceedings. See 8 C.F.R. $\S 1003.1(b)$ (2003) (delineating BIA's jurisdiction). There is a relatively small discrepancy between these data and the data reported by the EOIR in its statistical yearbooks. For instance, the FOIA data indicate that there were a total of 45,928 BIA decisions in fiscal year 2003, whereas the EOIR statistical yearbook for fiscal year 2003 reports this figure as 46,116 -a difference of 188 . We assume that this is due to corrections made to the EOIR data or from delayed reporting.

month also more than doubled from 1983.19 (with a standard deviation of 705.47) during the earlier period to 4094.37 (with a standard deviation of 788.60) during the later period. ${ }^{237}$ With more BIA decisions being issued

237. In this respect, the BIA's procedural changes appear to be accomplishing their goal of reducing the backlog. The EOIR reports that by the end of September 2004, the backlog of pending cases had shrunk to 33,544. See EOIR YB 2004, supra note 7, at U2. Furthermore, the age of the pending cases has also decreased substantially. Whereas $29 \%$ of the pending cases in October 2003 were over two years old, only $2 \%$ in September 2004 were over two years old. See id. 
each month, there are more decisions to be challenged.

\section{Appeal Rate}

The BIA's increased output, however, cannot account for the entire surge. Whereas the BIA's output has increased by a factor of around two, the courts of appeals' input of petitions for review has increased by a factor of closer to five. This difference indicates that a larger proportion of BIA decisions are now being challenged.

In Figure 5 we show the estimated rate of appeal for each month between November 1996 and May 2004, based on a comparison of the AO data with the EOIR's response to our FOIA request. We have estimated these rates by comparing the number of BIA decisions issued in each month $(m)$ with the number of petitions for review filed during the following month $(m+1)$. We begin our estimates in November 1996 because starting in that month, BIA decisions can be challenged through petitions for review only if the petitions are filed within thirty days of the BIA decision. ${ }^{238}$ We stagger the months on the assumption that people tend to wait more than fifteen days from the date of their BIA decisions to file their petitions for review and that no more BIA decisions are issued during the first half of the month than the second. ${ }^{239}$

As discussed above in Part III.E.1., these AO/EOIR appeal rate estimates are qualitatively different than the appeal rates we estimate by examining samples of BIA decisions from populations that were limited by certain

238. See supra notes $111-113$ and accompanying text.

239. If these assumptions hold, then of all the petitions for review challenging BIA decisions issued during month $m$, more should be filed during month $m+1$ than during month $m$. We tested the assumptions using the random sample of 548 BIA decisions discussed above in Part III.E.1. Of the 146 decisions that were challenged by way of petitions for review, the median day of the month on which the BIA decisions were issued was the 18 th, and the median length of time between the date of the BIA decision and the date on which the petition for review was filed was twenty-eight days. That is, half of the sampled BIA decisions from which petitions for review were filed were issued after the 18 th of the month, and half of the filed petitions for review were filed more than twenty-eight days after the issuance of the BIA decisions in question. Although our sampled variables do not appear to be normally distributed (based on Kolmogorov-Smirnov tests), we can nonetheless make conservative estimates, with $95 \%$ confidence, that the population median for the day of the month on which the BIA decision was issued lies between the 16th and the 20th, and that the population median for the length of time between the date of the BIA decision and the date on which the petition for review was filed lies between twenty-seven and twenty-nine. Thus, we are $95 \%$ confident that our assumptions hold. We have generated these confidence intervals by selecting order statistics to serve as our upper and lower confidence limits. We did so using the equation $(n+1) / 2 \pm z \sqrt{n} / 2$, where $z$ is the normal deviate corresponding to the desired confidence probability, which in our case we have rounded to $z=2$ to achieve 95\% limits. See generally SNEDECOR \& COCHRAN, supra note 205, at 135-37.

Of course, even if our assumptions hold, our estimates of rate of appeal will still contain errors because many petitions for review counted in month $m+I$ will actually be challenging BIA decisions issued during that month rather than month $m$. All our assumptions tell us is that it is more accurate to compare the petitions for review filed in month $m+l$ to the BIA decisions issued in month $m$ than it is to compare the petitions for review filed in month $m+l$ to the BIA decisions issued in month $m+l$. Although we can increase the accuracy of our estimates by comparing time intervals larger than one month (since this will dilute any errors, which occur only in the thirty-day intervals on either end of each period), this mainly results in a smoothing of the curve generated using our monthly intervals. We are therefore confident that the basic shape of the curve using one-month intervals is accurate, even if the precise rates for each month are not. 
parameters. Unlike the sample estimates, which filter out, among other things, BIA decisions that do not leave the alien with a final order of removal, the AO/EOIR estimates use, as their denominators, all BIA decisions in appeals from IJ proceedings. Furthermore, the AO/EOIR information can only provide estimates because it cannot link individual BIA decisions with petitions for review of those particular decisions. ${ }^{240}$

Keeping those limitations in mind, Figure 5 nonetheless strongly suggests that the rate of appeal has been increasing since March 2002. Our monthly data on BIA decisions ends with May 2004, but we can extend our estimates slightly further using the EOIR's published figure for the number of BIA decisions issued during fiscal year 2004 in appeals from IJ decisions: 46,053. ${ }^{241}$ By subtracting the number of such BIA decisions issued between October 1, 2003, through May 31, 2004 (reported in the FOIA data), we calculate that the BIA issued 14,888 such decisions between June 1 and September 30, 2004. During that same period, 3857 petitions for review were filed, giving us an estimated appeal rate of about $26 \%{ }^{242}$ Whether this indicates that the appeal rate is leveling off or whether it will continue to rise remains to be seen.

Having already observed that the Second and Ninth Circuits receive the highest volume of petitions for review, one obvious question is whether this is because they have higher rates of appeal than other circuits. Our data on this question are much more limited, but we have arrived at some estimates by comparing, for each circuit, the volume of BIA decisions that could have been challenged in petitions for review in that circuit (assuming they could have been challenged at all) with the volume of petitions for review filed in that circuit. As discussed above in Part II, a petition for review must be filed in the circuit within which the IJ completed proceedings. ${ }^{243}$ The first step in estimating a circuit level appeal rate is therefore to determine where the IJ completed proceedings in each case that led to a BIA decision. We did this for

240. We have not attempted to calculate the exact rates of appeal (which would require linking each petition for review with a BIA decision) because we do not currently have the capacity to do this. If we had full access to a complete database of BIA decisions, we could presumably link it with the A-numbers listed for each petition for review filed in the courts of appeals. However, we have only limited access to the BIA's internal database, and that database is not complete for older cases. See Update on the BIA, supra note 196 . We were initially hopeful that we could obtain the monthly appeal rate from the EOIR, but the response to our FOIA request was that the EOIR does not track that information. See Letter from Crystal Souza, EOIR Paralegal Specialist, to John R.B. Palmer (Oct. 18, 2004) (on file with authors).

241. See EOIR YB 2004, supra note 7.

242. The figure for petitions for review comes from the Administrative Office dataset. Because that dataset extends only until September 2004, we are unable to use the staggering method discussed above in note 242 and accompanying text. However, we can assume that any resulting error is relatively small, given that it should occur only in the thirty-day intervals at either end of the period. If we compare the total fiscal year 2004 BIA decisions (in appeals from $1 J$ decisions) with the total number of petitions for review filed in fiscal year $2004(10,804)$, we estimate an appeal rate of approximately $27 \%$.

243. See supra notes $108-110$ and accompanying text. 
FIGURE 5. ESTIMATED APPEAL RATE FOR BIA DECISIONS ARISING FROM IJ PROCEEDINGS

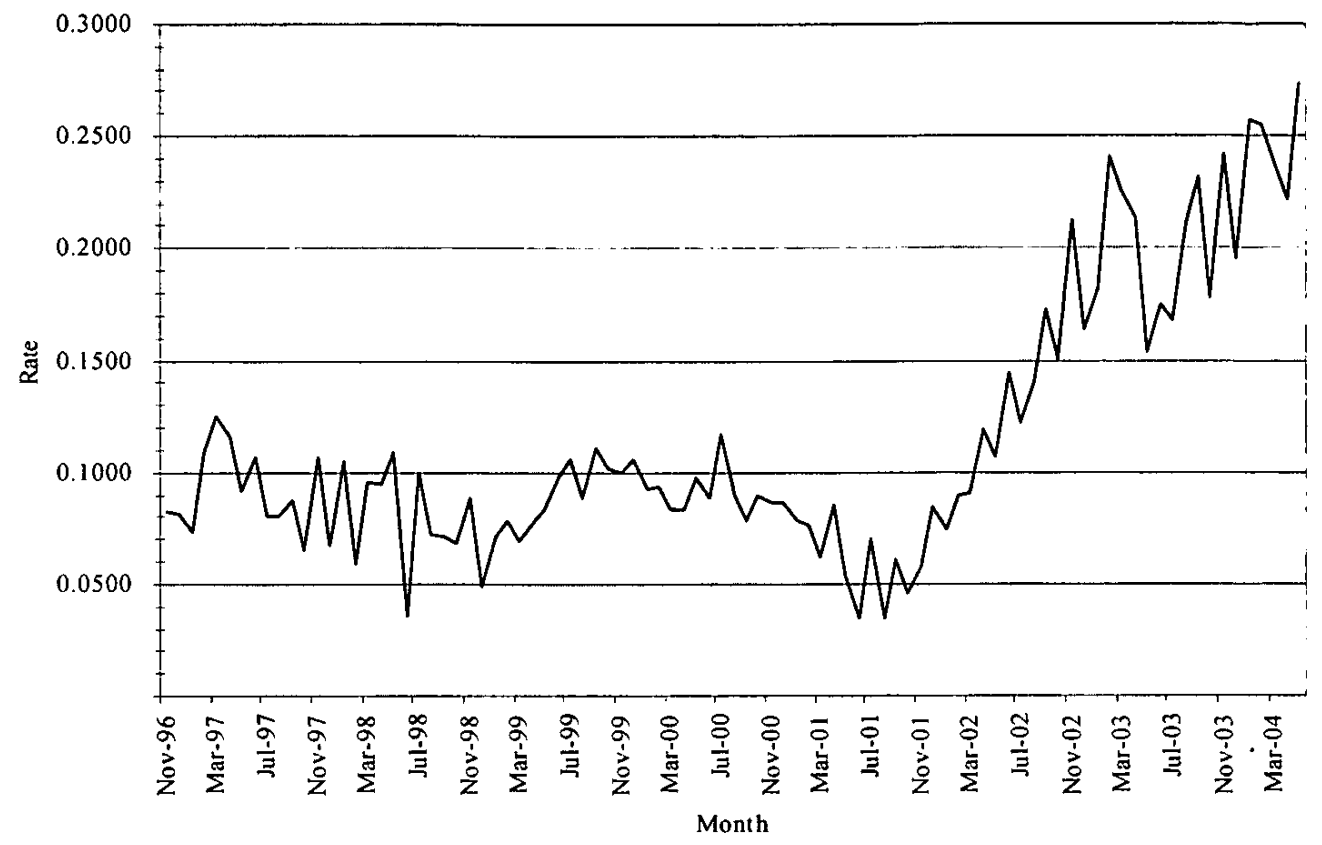

Source: Administrative Office data series, see supra Part III.A., and EOIR response for authors' FOIA request, see supra Part III.D.

Note: Rate is calculated by dividing the number of petitions for review filed in month $m+l$ by the number of BIA decisions issued in month $m$. The dates on the $\mathrm{x}$-axis represent month $m$.

all of the BIA decisions issued between May 1 and August 31, 2004, in direct appeals from IJs, and we thereby sorted each of these decisions according to the circuit that would have had jurisdiction over a petition for review (assuming that no other jurisdictional defects existed). ${ }^{244}$ By comparing these figures with the number of petitions for review filed between June 1 and September 30, 2004, we arrived at the estimates, shown in Table 1, for the rate of appeal in each circuit during that period of time.

What we see is a significant variation in appeal rate between the circuits. Petitions for review were filed from approximately $42 \%$ of the BIA decisions arising in the Second Circuit and from approximately $45 \%$ of the BIA decisions arising in the Ninth Circuit. In contrast, they were filed from only about $9 \%$ of the BIA decisions issued in the Eleventh Circuit. Unfortunately, we are able to use this method for estimating the circuit appeal rates only for BIA decisions issued after May 2004 because we do not have comprehensive information on the circuits in which earlier BIA decisions arose.

244. See supra Part III.C. 2 for these calculation methods. 
TABLE 1: ESTIMATED APPEAL RATE FOR BIA DECISIONS IN DIRECT APPEALS FROM

IJS BY CIRCUIT

\begin{tabular}{|l|c|c|c|}
\hline Circuit & $\begin{array}{c}\text { Number of BIA } \\
\text { decisions issued } \\
\text { from May through } \\
\text { August 2004 }\end{array}$ & $\begin{array}{c}\text { Number of petitions } \\
\text { for review fled } \\
\text { from June through } \\
\text { September 2004 }\end{array}$ & $\begin{array}{c}\text { Estimated rate } \\
\text { of appeal }\end{array}$ \\
\hline D.C. Cir. & 0 & 0 & n.a. \\
\hline 1st Cir. & 239 & 55 & $23 \%$ \\
\hline $2 d$ Cir. & 2,231 & 945 & $42 \%$ \\
\hline 3 d Cir. & 607 & 207 & $34 \%$ \\
\hline 4 th Cir. & 500 & 134 & $27 \%$ \\
\hline 5th Cir. & 690 & 166 & $24 \%$ \\
\hline 6th Cir. & 266 & 97 & $36 \%$ \\
\hline 7 th Cir. & 272 & 77 & $28 \%$ \\
\hline 8th Cir. & 81 & 49 & $60 \%$ \\
\hline 9th Cir. & 4,283 & 1,918 & $45 \%$ \\
\hline 10th Cir. & 131 & 37 & $28 \%$ \\
\hline 11th Cir. & 1,996 & 172 & $9 \%$ \\
\hline Total & 11,296 & 3,857 & $34 \%$ \\
\hline
\end{tabular}

Source: Random sample of BIA decisions issued between May 1 and August 31, 2004, in direct appeals from IJs, and Administrative Office data series. See supra Part III.E.2.

Note: Estimated rate of appeal is calculated dividing the number of petitions for review filed from June through September 2004 by the number of BIA decisions issued from May through August 2004.

\section{EXPLAINING THE INCREASEd APPEAL RATE}

If the BLA's output alone could account for the increase in the volume of petitions for review, this would be the end of our inquiry. The increased appeal rate, however, makes things more complicated because there are a large number of variables that might help to explain it, and testing these variables proves tricky. Given the small amount of available data, the best we can hope to do at this stage is to propose a set of candidate variables and use the data we have to show that some of these are more likely to be responsible than others.

As noted in the introduction, the EOIR and a Commission of the ABA have each proposed different explanations for the immigration surge. For the ABA Commission, the critical change is an increase in summary decisions, which are more likely than standard decisions to be either erroneous, perceived as erroneous, or simply unacceptable to the litigants; for the EOIR, it is an increase in prompt decisions, which cause aliens to seek new mechanisms for 
delay. We examine these variables and propose additional ones as well.

We start by viewing the pool of BIA decisions not as a homogenous group, but instead as a composite of sub-groups, each comprising decisions that share certain characteristics, and each having a different rate of appeal. We explore whether the appeal rate for the whole pool of BIA decisions may have increased simply because of changes in the proportion of each subgroup. We examine various sub-groups of BIA decisions to see whether they might be appealed at higher rates than others, and if so, whether they might have increased in proportion to the others during the time period in which the overall appeal rate increased. Next, we explore whether the appeal rate for certain sub-groups of BIA decisions may have changed over time. We examine various characteristics of the BIA, the courts of appeals, the immigration bar, and the litigants themselves, to see whether they might have influenced such changes.

\section{A. Composition of the Pool of BIA Decisions}

All of our estimates of appeal rate have so far treated BIA decisions as a mostly homogenous group. While we have focused on BIA decisions in appeals arising from IJs (and sometimes limited this to direct appeals from IJs), and while we have broken down these decisions by judicial circuit, we have not looked further at the variation among BIA decisions. In reality, however, the BIA decides many different types of cases, using different procedures, and reaching different outcomes. These differences can affect the likelihood that a particular BIA decision will be appealed. If we were to separate the pool of BIA decisions into sub-groups according to certain characteristics, we might find that each sub-group has a different rate of appeal. Furthermore, we might find that the proportion of each sub-group within the pool of BIA decisions changes over time. This might result from changes in the way the BIA decides cases, the composition of the pool of cases that the BIA chooses to decide in a given period of time, or the composition of the pool of $\mathrm{IJ}$ decisions that are appealed to the BIA. Whatever the cause, a change in composition of BIA decisions could affect the overall rate of appeal.

\section{Outcome}

The most straightforward characteristic that could affect appeal rate is outcome. A BIA decision that does not leave the alien with a final order of removal generally cannot be challenged in a petition for review, so we should expect attempts at such challenges to be extremely rare. ${ }^{245}$ If we were to

245. Again, this is not to say that such challenges cannot be brought, simply that they generally cannot be brought as petitions for review, and so are not factored into our measurement of appeal rate. See supra notes 99-107 and accompanying text. 
divide the pool of BIA decisions into a sub-group of decisions that constitute final removal orders and a sub-group of those that do not, we would expect that the appeal rate for the latter sub-group to be dramatically lower than the appeal rate for the former. Consequently, an increase in the proportion of BIA decisions that constitute final orders of removal should cause an increase in the overall rate of appeal.

We do not have much data on the outcome of BIA decisions, but two sources suggest that the proportion of BIA decisions resulting in final orders of removal increased substantially in 2002. First, the Los Angeles Times reports that the BIA rejected $86 \%$ of its appeals in October 2002 as compared with $59 \%$ the previous October. ${ }^{246}$ Although the BIA's Chairman has disputed the accuracy of these figures, ${ }^{247}$ a subsequent study by the United States Commission on International Religious Freedom (USCIRF) also shows a substantial increase in the proportion of BIA decisions that reject aliens' appeals: from $87 \%$ in fiscal year 2001, to $98 \%$ in fiscal year 2002 , $97 \%$ in fiscal year 2003 , and $96 \%$ in fiscal year $2004 .{ }^{248}$ The USCIRF study looks only at asylum seekers subject to expedited removal proceedings, so these figures may not reflect the actual rejection rate for the overall pool of appeals. It seems reasonable to assume, however, that whatever the overall rejection rate was, it increased between 2001 and 2002 for the same reasons that the rejection rate for expedited removal appeals increased.

Even leaving the empirical evidence aside, it would simply make logical sense that the BIA started rejecting a larger proportion of appeals in 2002 , because it came under increased pressure to clear its backlog, and it was directed to give more deference to IJ findings of fact. Whereas the BIA previously reviewed findings of fact de novo, it now reviews them only for clear error. Given this change in standards, it would be surprising if the BIA was not rejecting a larger proportion of appeals. Further, since the vast majority of appeals at the BIA level are filed by aliens as opposed to DHS, ${ }^{249}$

246. Lisa Getter \& Jonathan Peterson, Speedier Rate of Deportation Rulings Assailed, L.A. TimEs, Jan. 5, 2003, at A1. The paper also published a table on its website, showing, among other things, the BIA's monthly rejection rate from June 2000 through October 2002. The figures for monthly rejection rate for 2001 ranged from $35 \%$ to $72 \%$, with an average of $62 \%$. For March through October 2002 , they ranged from $78 \%$ to $86 \%$, with an average of $81 \%$. This table is no longer available online, but it is reported graphically in DORSEY \& WHITNEY LLP, supra note 5, at app. 24.

On May 2, 2005, the Los Angeles Times reported that "[f]ive years ago, the BIA ruled in favor of immigrant appeals $9 \%$ of the time. By 2003 , immigrants won their appeals $6 \%$ of the time." Moore \& Simmons, supra note 17. It is not clear where these figures come from.

247. See Lori Scialabba, Letter to the Editor L.A. TIMES, Jan. 9, 2003, available at http:// www.usdoj.gov/ eoir/press/ 03/getter.pdf; Letter from Lori Scialabba to ABA, supra note 238 (stating that the Los Angeles Times statistics were "unsubstantiated").

248. USCIRF, supra note 39, at 22, 672 tbl.6; Susan Kyle, Cory Fleming \& Fritz Scheuren, Statistical Report on Immigration Court Proceedings: FY 2000-2004, in REPORT ON AsYLUM SEEKERS IN EXPEDITED Removal 383, 413-15 (2005). In criticizing the Los Angeles Times figures, Chairman Scialabba wrote that "the Board does not track decisions by outcome." Letter from Lori Scialabba to ABA, supra note 235. The USCIRF study, however, indicates that that EOIR does track this information.

249. See Kyle, Fleming \& Scheuren, supra note 248 , at 413. 
an increase in rejection rate should mean an increase in the proportion of final orders of removal.

Finally, some observers have suggested that when the Attorney General reduced the size of the BIA from twenty-three authorized members to eleven, he did so by removing those members who were most prone to disagree with his positions. These observers further suggest that the reduction was carried out in such a way as to implicitly threaten the job security of the remaining members, and thus undermine their decisional independence. ${ }^{250}$ If the observers are correct, this could have further contributed to an increase in final orders of removal. ${ }^{251}$

Assuming that final orders of removal did increase, and given that such orders are almost certainly appealed at a higher rate than other BIA decisions, the critical question is exactly how much did the proportion of final orders of removal increase, and how much of the observed increase in appeal rate does this account for? In the absence of further data, we leave this question for a future study.

\section{Error}

Error is another obvious characteristic that should affect appeal rate, although it is one that is hard to measure systematically. An increase in the proportion of BIA decisions that contain reversible error should increase the overall appeal rate, assuming that the error is noticed by effected noncitizens and that there is not something else (like lack of access to counsel) standing in the way of appealing to the federal courts. We have seen a number of glaring errors in the BIA's summary decisions, but it is very hard to estimate the actual error rate. ${ }^{252}$

The best way to estimate error rate would probably be to have an independent group review samples of BIA decisions. However, obtaining sufficiently large samples of decisions issued during the time periods before and after the expansion of streamlining is extremely costly. As an alternative, we have calculated reversal rates and settlement rates, but with the understanding that these are of limited value. The reversal rates tell us only about reversible error in the pool of BIA decisions that were actually reviewed on

250. See Legomsky, supra note 54; Levinson, supra note 170.

251. See E-mail from Professor Stephen H. Legomsky, Charles F. Nagel Professor of International and Comparative Law, Washington University in St. Louis School of Law, to John R.B. Palmer (Aug. 12, 2005, 07:50:55 MT) (on file with authors).

252. Many of the glaring errors have been well documented in DORSEY \& WHITNEY LLP, supra note 5, and in an article by former Board Member Lory Rosenberg, supra note 5. Neither of these surveys, however, purports to provide a systematic analysis of error rate. Of course, as former Board Member Rosenberg points out, erroneous BIA decisions have "an exceptionally high human cost" that is "difficult to discount or justify using percentages." $l d$. Or, as another immigration professor put it while we were discussing this article with him, "I don't care about statistics, I care about justice!" The point is well-taken. While we are focused here on explaining the surge in petitions for review, there is clearly a lot more at stake than numbers for the people who are actually being expelled. 
the merits by judges. They tell us nothing about those decisions that were never challenged, those that were settled by the parties before reaching panels of judges, or those that were dismissed for lack of jurisdiction. We have calculated settlement rates to factor in that group of decisions, but unfortunately our data do not allow us to distinguish between settlements involving remands to the BIA (which may indicate error), and settlements in which the alien simply withdraws the petition for review (which presumably do not involve error).

Our calculations focus on the month in which a petition for review was filed, rather than the month in which it was decided, because the former gives us information about when the BIA decision in question was issued. For each month $m$, we calculated the proportion of the total cases filed during $m$ that ultimately resulted in either reversal, vacatur, or remand, in whole or part, on the merits. ${ }^{253}$ We term this proportion the reversal rate. We also calculated the proportion of the total cases filed during each month that were ultimately either settled or dismissed pursuant to Federal Rule of Appellate Procedure 42(b). ${ }^{254}$ We term this proportion the settlement rate. For both measurements, our information on outcomes was limited to data reported as of September 2004.

In Figure 6, it is apparent that both the reversal and settlement rates fluctuated widely for BIA decisions issued since October 1994, but neither appears to have increased substantially since March 2002. There is a large spike in reversal rate for cases filed in April 1997, which clearly reflects the Eleventh Circuit's $N-J-B$ - remands, as discussed above. ${ }^{255}$ There are then smaller spikes in reversal rate for cases filed in June 2001 and February 2002, as well as a dip in December 1999. With respect to settlement rate, we see spikes for cases filed in June 1998, July 1999, and July 2001, the second of which is clearly accounted for by the Second Circuit cases that settled as a result of Henderson v. INS. ${ }^{256}$ Finally, both rates decrease steadily starting on October 1, 2002, but that is almost definitely an artificial trend caused by a parallel drop in the proportion of cases that had been terminated as of September 2004 (when our data were collected). ${ }^{257}$

253. We selected these cases from the Administrative Office data, specifically those in which the "OUTCOME" field, or, for data files before fiscal year 1998, the "ACTION ON THE MERITS" field, was coded with " 2 ," "3," or "6."

254. See FED. R. APP. P. 42(b). We selected these cases from the Administrative Office data, specifically those in which the "PROCTERM" field, or, for data files before 1998, the "PROCEDURAL TERMINATIONS" field, was coded with " 2 " or " 3 ," as well as those in which the "METHOD" field, or, for data files before fiscal year 1998, the "NO JUDICIAL ACTION" field, was coded with " 1 " or " 2 ."

255. See supra note 229 and accompanying text.

256. See supra notes $230-233$ and accompanying text.

257. One might think that this problem could be avoided by measuring rate using the pool of terminated cases as the denominator instead of the total number of cases. The problem with that approach, however, is that there is another "censoring" effect: reversals and settlements are not evenly distributed across the period of time needed to terminate all of the cases filed during a given month. Instead, reversals tend to be clustered at the end of the period and settlements at the 
In looking at these data, we need to keep in mind that they give us only limited information about the rate of error or perceived error in BIA decisions. Furthermore, these data cover only a short period after March 2002. It is possible that other measures of error would lead us to different conclusions. Additionally, the data available in future years may elucidate a trend that we have not yet detected. For now, however, our data do not suggest that there has been an increase in error rate at the BIA level. ${ }^{258}$

\section{Adjudicatory Procedure and Form of Decision}

The procedure the BIA uses to adjudicate a case and the form of the decision it issues are the characteristics on which the ABA Commission and many others have focused. As the Commission pointed out, decision-making by a single Board member, the availability of affirmances without opinion, and the elimination of de novo review are all likely to lead to more errors and therefore more appeals. ${ }^{259}$ To the extent that this is the case, these variables are obviously linked to the ones explored above. In addition, summary procedures may also be linked to outcome, in that they are likely to favor affirmances of IJ decisions and thus final orders of removal. Finally, summary procedures can create the perception of error and can undermine litigants' confidence in a particular decision, thereby encouraging appeals. Aliens facing removal orders may be more prone to file petitions for review from summary decisions, and lawyers may be more willing to take weak cases when they feel that the BIA's procedures were unfair or otherwise flawed. Indeed, until the courts of appeals rejected such challenges, many lawyers argued that the summary procedures themselves violated due process and basic principles of administrative law. The lawyers therefore argued that

beginning. This tendency makes sense if we think of the life cycle of an appeal. It is also confirmed by the data-at least in the case of reversals-for most of the filing months that we looked at. Therefore, by excluding outcomes that take place after a certain date, we are likely to exclude a disproportionately large number of reversals and a disproportionately small number of settlements. $C f$. Kuo-Chang Huang, Mandatory Disclosure: A Controversial Device With No Effects, 21 PACE L. REv. 203, 246-47 (2000) (discussing a similar problem that arises when analyzing case-processing time in a data series that ends before all cases have been terminated).

258. One additional piece of information we have on reversal rate is the EOIR's calculation that of the 23,224 streamlined decisions between 1999 and 2001 , only $0.7 \%$ had resulted in judicial remands or reversals as of Aug. 26, 2002. See Board of Immigration Appeals: Procedural Reforms to Improve Case Management, 67 Fed. Reg. 54,878-01, 54,885 (Aug. 26, 2002). A problem with this statistic, however, is that it uses the total number of streamlined decisions as its denominator, rather than the number of streamlined decisions that were actually appealed. See Capital Area Immigrants' Rights Coal. v. U.S. Dep't of Justice, 264 F. Supp. 2d 14, 29-30 (D.D.C. 2003). Another flaw is that the statistic presumably suffers from the "censoring" effect discussed above. See supra note 257 and accompanying text. Further, we note that the categories of appeals eligible for streamlining during that period appear to have been dominated by the types of cases that tend not to be challenged in petitions for review. This is in contrast to the streamlined cases after March 2002, which appear to have included a significant number of asylum decisions for the first time. See supra Part II.C.2; infra Part V.A.5.

259. See ABA Report, supra note 8. 
FiguRE 6: MONTHLY REVERSAL AND SETTLEMENT RATES NATIONWIDE

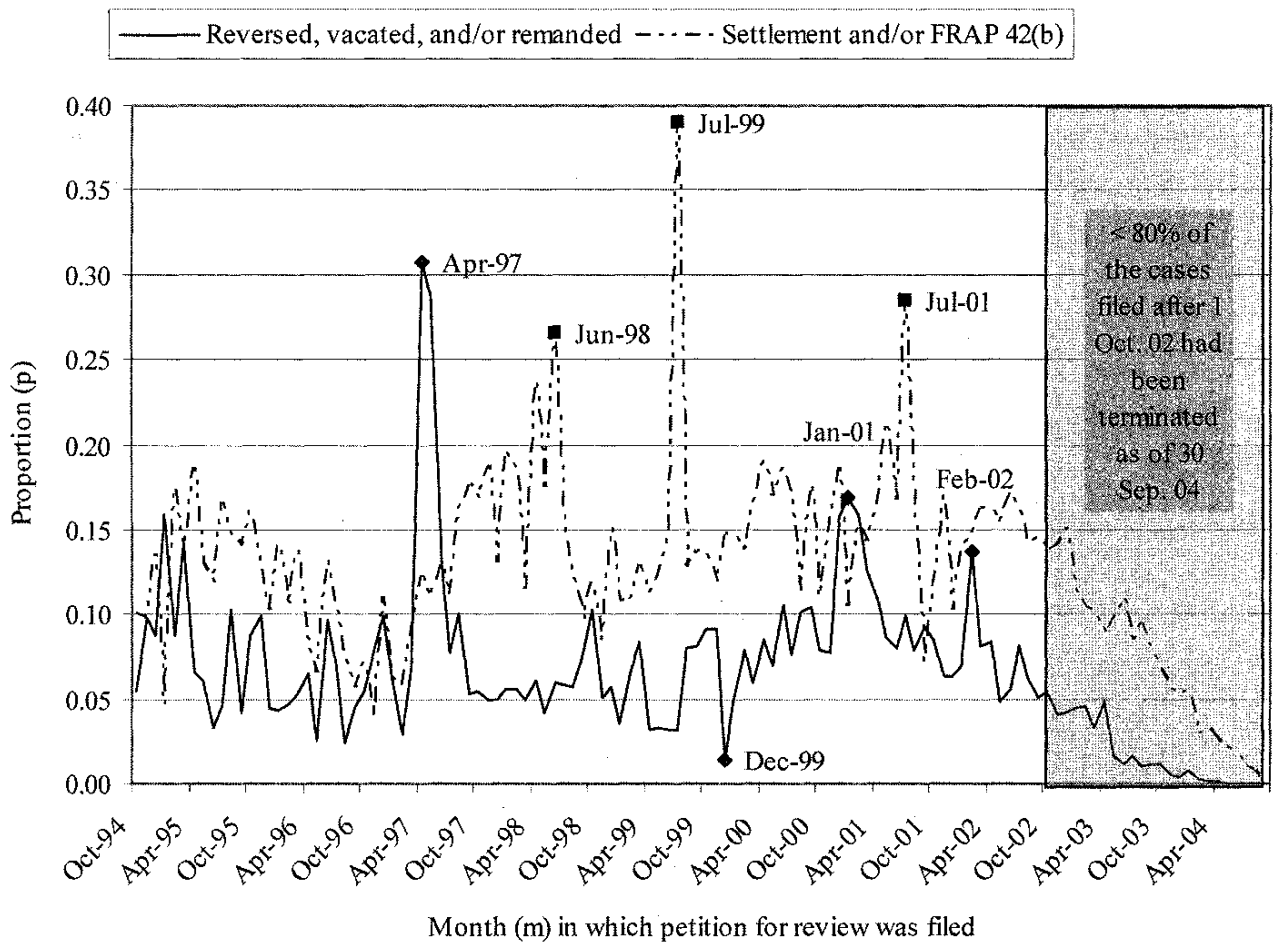

Source: Administrative Office data. See supra Part III.A.

Note: Proportion $p$ is calculated by dividing the number of petitions for review in the specifeid category filed during month $m$ by the total number of petitions for review filed during month $m$. The area of the chart to the right of October 2002 is shaded to indicate that less than $80 \%$ of the petitions for review filed during these months were terminated as of September 2004. These observed proportions are therefore not accurate measures of the actual rates.

any decision produced by these procedures contained error. ${ }^{260}$

Since March 2002, there has been an increase in the proportion of summary decisions within the pool of BIA decisions. On March 25, 2002, the BIA Chairman expanded the categories of appeals eligible for affirmance without opinion. ${ }^{261}$ The resulting increase in the proportion of summary decisions is apparent from the data reported in a number of sources. ${ }^{262}$ In contrast to the characteristics we have considered thus far, the critical question about summary procedures is not whether their proportions have changed, but whether such a change would affect appeal rate.

We explored this question by examining a representative sample of 428 BIA decisions. As described above in Part III, we drew our sample from a

260. See supra note 157 and accompanying text.

261. See supra notes $144-145$ and accompanying text.

262. See DORSEY \& WHITNEY LLP, supra note 5, at apps. 24-25; see infra app. Table 20. 
population of BIA decisions with the following characteristics: (1) the decisions were issued between May 1 and August 31, 2004; (2) the decisions were in appeals taken directly from IJ decisions in removal proceedings; (3) where the BIA decisions constituted final orders of removal; ${ }^{263}$ (4) where the aliens did not withdraw or abandon their appeals before the BIA issued its decisions; and (5) where the BIA did not dismiss the petitions as untimely. Of the 428 sampled decisions that fell within our population parameters, 415 were decided by single Board members, 246 were summary affirmances, and nineteen were summary dismissals. For each of these procedural characteristics, we calculated the exact appeal rate for the group of decisions first with the characteristic and then without it. We present this data, along with tests for significance, in Tables 2 through 4.

The only statistically significant difference that we detect is the difference between the $0 \%$ appeal rate for summary dismissals and the $35 \%$ appeal rate for decisions that were not summary dismissals. We evaluated this difference using a Fisher's exact test (due to the small number of summary dismissals), ${ }^{264}$ and the test indicates that there is less than a $0.1 \%$ chance that the difference is due to random variation alone. We are therefore confident that people are challenging summary dismissals in petitions for review at a lower rate than they are challenging other types of BIA decisions.

In contrast, we detected no statistically significant differences between the appeal rates of single-member decisions and three-member decisions or between the appeal rates of affirmances without opinion and decisions with opinions. For the comparison between single-member and three-member decisions, the sample tells us very little because it contains so few singlemember decisions. We were thus very unlikely to detect a statistically significant result even if one existed. ${ }^{265}$ For the comparison between decisions with and without opinions, our sample was not large enough to rule out a relatively small difference in appeal rates. However, we can rule out a large difference. ${ }^{266}$

In addition to the problem of sample size, one must be careful in drawing conclusions from these data for a number of reasons. First, we have taken our sample from the population of BIA decisions issued during a discrete period

263. As discussed above, we included in these final orders of removal BIA decisions that granted voluntary departure. See supra note 195.

264. See generally FLEISS, supra note 206, at 24-26.

265. If the actual appeal rate in the population was $33 \%$ for single-member decisions and $46 \%$ for three-member decisions, we had less than a $10 \%$ chance of obtaining a statistically significant result detecting such a difference, given our sample size and the prevalence of single-member decisions in our sample. This calculation is based on FLEISs, supra note 206, at 38-46.

266. If there is a difference, and if it is in fact a $35 \%$ rate for affirmances without opinion versus a $32 \%$ rate for other decisions, as we found in our sample, we had less than a $10 \%$ chance of obtaining a statistically significant result that detected such a difference given our sample size. On the other hand, if the rate was $42 \%$ for affirmances without opinion and $25 \%$ for other decisions, we had a $95 \%$ chance of detecting such a difference, given our sample size. This calculation is based on FLEISS, supra note 206 , at $38-46$. 
TABLE 2: SAMPLE APPEAL RATES FOR SUMMARY DISMISSALS AND OTHER FINAL ORDERS OF REMOVAL

\begin{tabular}{|l|l|c|c|c|}
\hline & & \multicolumn{3}{|c|}{ Petition for review filed? } \\
\hline & & No & Yes & Total \\
\hline \multirow{3}{*}{$\begin{array}{l}\text { Summary } \\
\text { dismissal? }\end{array}$} & No & $265(65 \%)$ & $144(35 \%)$ & $409(100 \%)$ \\
\cline { 2 - 5 } & Yes & $19(100 \%)$ & $0(0 \%)$ & $19(100 \%)$ \\
\cline { 2 - 5 } & Total & $284(66 \%)$ & $144(33 \%)$ & $428(100 \%)$ \\
\hline
\end{tabular}

Fisher's exact test (2-tailed): 0.001

Source: Random sample of BIA decisions issued between May 1 and August 31, 2004 , in direct appeals from IJs and courts of appeals docket databases. See supra Part III.E.3.

TABLE 3: SAMPLE APPEAL RATES FOR SINGLE-MEMBER DECISIONS AND OTHER FINAL ORDERS OF REMOVAL

\begin{tabular}{|l|l|c|c|c|}
\hline & & \multicolumn{3}{|c|}{ Petition for review filed? } \\
\hline & & No & Yes & Total \\
\hline \multirow{2}{*}{$\begin{array}{l}\text { Single- } \\
\text { member } \\
\text { decision? }\end{array}$} & No & $7(64 \%)$ & $6(46 \%)$ & $13(100 \%)$ \\
\cline { 2 - 5 } & Yes & $277(67 \%)$ & $138(33 \%)$ & $415(100 \%)$ \\
\cline { 2 - 5 } & Total & $284(66 \%)$ & $144(33 \%)$ & $428(100 \%)$ \\
\hline
\end{tabular}

Fisher's exact test (2-tailed): 0.376

Source: Random sample of BIA decisions issued between May 1 and August 31, 2004 , in direct appeals from IJs and courts of appeals docket databases. See supra Part III.E.3.

TABLE 4: SAMPLE APPEAL RATES FOR AWOS AND OTHER FINAL ORDERS OF REMOVAL

\begin{tabular}{|l|l|c|c|c|}
\hline & & \multicolumn{3}{|c|}{ Petition for review fled? } \\
\hline & & No & Yes & Total \\
\hline \multirow{3}{*}{$\begin{array}{l}\text { Affirmance } \\
\text { without } \\
\text { opinion? }\end{array}$} & No & $123(68 \%)$ & $59(32 \%)$ & $182(100 \%)$ \\
\cline { 2 - 5 } & Yes & $161(65 \%)$ & $85(35 \%)$ & $246(100 \%)$ \\
\cline { 2 - 5 } & Total & $284(66 \%)$ & $144(34 \%)$ & $428(100 \%)$ \\
\hline
\end{tabular}

$\chi^{2}=0.214$

$p(1$ d.f. $)=0.644$

Source: Random sample of BIA decisions issued between May 1 and August 31, 2004 , in direct appeals from IJs and courts of appeals docket databases. See supra Part III.E.3.

of time. Therefore, we do not know what we would have found during other periods. While it may be that affirmances without opinion or one of the other procedures were what initially sparked the immigration surge, the dynamics 
may have since changed. In fact, it is likely that summary decisions were appealed at a higher rate during the period before the courts of appeals rejected the facial challenges to these procedures because such challenges provided colorable claims that could form the basis of an appeal from any summary decision.

Second, we have not controlled for sources of variability other than the procedure used. Such variability almost definitely exists, and it is very likely to have skewed our results. In particular, the way the BIA selects the cases for each procedure may be a more important determinant of appeal rate than the procedures themselves. For example, summary dismissals are authorized mostly in situations of procedural default, such as when the alien indicates that the appeal will be supported by a brief or statement but then fails to file either document. ${ }^{267}$ In such situations, it is unlikely that a petition for review would be successful. ${ }^{268}$ Moreover, the root cause of the procedural default at the BIA level-lack of legal competence, lack of resources, etc.-may also prevent a properly filed petition for review. Thus, although our data show that summary dismissals are appealed at a significantly lower rate than other decisions, no one would argue that this result is due to the procedure or the form of decision; instead, it is most likely due to the underlying nature of the cases in which the procedure is employed.

Similarly, the BIA is supposed to affirm without opinion when then appeal is either particularly weak or particularly straightforward. The pool of decisions that are affirmed without opinion should therefore be expected to have an inherently lower appeal rate than the pool of decisions that do not employ this procedure, without taking into consideration any effects of the procedure itself. Thus, the fact that we observed equivalent appeal rates may actually reflect an increase in the appeal rate as a result of the procedure.

To really test the effects of each summary procedure, one would need to conduct a controlled experiment. ${ }^{269}$ Such an experiment could only be conducted by or in close cooperation with the EOIR, and it is not clear that the EOIR is ready to commit to such a task. ${ }^{270}$

\section{Promptness of Decision}

The EOIR has proposed that the critical characteristic on which to focus is

267. See 64 Fed. Reg. 56,141 (Oct. 18 1999); 8 C.F.R. $\$ 3.1$, reprinted in DORSEY \& WHITNEY LLP, supra note 5.

268. See INA $\S 242$ (a)(1), (d), 8 U.S.C. $\$ 1252$ (a)(1), (d) (2000); Smith, supra note 88, at 710 n.141; supra note 94 and accompanying text.

269. Cf., e.g., Jerry Goldman, An Evaluation of the Civil Appeals Management Plan: An Experiment in Judicial Administration, reprinted, in part, in MANAGING APPEALS IN FEDERAL COURTS 21 (Robert A. Katzmann \& Michael Tonry eds., 1988); Jerry Goldman, The Civil Appeals Management Plan: An Experiment in Appellate Procedural Reform, 78 ColuM. L. REV. 1209 (1978); Anthony Partridge \& Allan Lind, A Reevaluation of the Civil Appeals Management Plan, reprinted, in part, in Managing Appeals in Federal Courts 89; see generally Thomas E. Willging, Past and Potential Uses of Empirical Research in Civil Rulemaking, 77 NOTRE DAME L. REV. 1121 (2002).

270. See 67 Fed. Reg. 54, 885 (Aug. 26, 2002); DORSEY \& WhITNEY LLP, supra note 5. 
the time required to process a case, and specifically, that prompt decisions are appealed at a higher rate than delayed decisions. The theory is not that the appeal rate is being driven by aliens seeking as much delay as possible. If that were the case, then the promptness of the BIA's decisions would not make any difference, as petitions for review would be filed in any event. Instead, the theory is that there are aliens who will delay their expulsion proceedings only for a certain period of time, during which they will keep litigating their case, either at the BIA or in the federal courts if necessary. After that period of time, however, these aliens will not pursue any further litigation.

Though this theory may seem counterintuitive at first, it is not an unreasonable proposition. Many aliens probably intend to remain in the United States only long enough to make a certain amount of money before returning to their countries of origin. ${ }^{271}$ A delay at the BIA may allow such aliens to remain for the desired period of time, and in such situations, there would be little reason to file a petition for review. Thus, these aliens may have found new reason to file petitions for review when the BIA began deciding cases in a timelier manner.

Even for aliens who wish to remain in the country permanently, a delay in expulsion proceedings often results in the availability of alternate forms of relief. For instance, a person may find a spouse or an employer while proceedings are pending and then adjust status. We need not attribute frivolous motives to such people for the theory to hold. These people may raise colorable claims in their expulsion proceedings and simply happen to find alternate relief while the proceedings are pending. All that is needed is the existence of a group of people who will refrain from filing a petition for review if proceedings are delayed beyond a certain time at the administrative level.

If the theory is correct, then we would expect to see some sort of relationship between the length of time that a class of cases spends at the administrative level and the rate of appeal for that class. We should at least see a class of cases arising after March 2002 that (1) has spent less time at the administrative level than the average time for a case decided prior to March 2002 , and (2) is challenged through petitions for review at a higher rate than the overall rate of appeal prior to March 2002. ${ }^{272}$ Ideally, we would observe

271. See, e.g., CHIN, supra note 24, at 114 (quoting a man who had been smuggled from Fujian province, was dissatisfied with life in the United States, and wanted to return home after clearing his debts and saving $\$ 10,000$ to $\$ 20,000$ ); $i d$. at 128,182 app. B, tbl.13 (reporting that eighty-five out of the 300 smuggled Chinese whom the author interviewed in New York planned to return to China after making enough money).

272. We might also see a class of cases shrinking or disappearing after February 2002 that (1) has spent more time with the BIA than the average time prior to March 2002, and (2) that is (or was) challenged in petitions for review at a lower rate than the overall rate of appeal prior to March 2002. Since the number of BIA decisions being issued since March 2002 has increased, however, any shrinkage or disappearance in one class must be accompanied by an increase in another. For the EOIR theory to hold in such a situation, the type of growth or appearance described in the text must occur. 
cases both before and after March 2002, using the earlier period as our baseline.

In practice, however, we were constrained by limited access to data, and we had to rely on our sample of 428 BIA decisions issued between May 1 and August 31, 2004. For each decision in the sample, we recorded the "age" of the case-that is, the amount of time between the commencement of removal proceedings (or deportation or exclusion proceedings in pre-IIRIRA cases) and the dates of the BIA decisions in question. ${ }^{273}$ We then divided the BIA decisions into those that were subsequently challenged in petitions for review and those that were not.

We found that the pool of sampled BIA decisions that were challenged in petitions for review were, on average, older than the pool of sampled BIA decisions that were not challenged. The mean age of the pool of decisions that were challenged in petitions for review was 1276 days ( 3.5 years), while the mean age of the BIA decisions that were not challenged was 1051 days (2.9 years). The distribution in each case is too far from normal to confidently compare the means using a t-test, but a Mann-Whitney test indicates that the difference is statistically significant. We also found that the ages within the complete sample of 428 BIA decisions ranged from 146 days ( 0.4 years) to 6535 days ( 17.9 years), with a mean of 1126.43 days ( 3.1 years).

In Figure 7, we divided case age into 180-day intervals (i.e., 1 interval $=0$ through 180 days, 2 intervals $=181$ through 360 days $\ldots$ ) and plotted each interval against the rate of appeal for that interval. We found that, if anything, the rate of appeal tends to increase more than decrease with each increase in interval number.

Although there is too much heteroscedasticity in this plot to directly calculate a least squares regression line with confidence, ${ }^{274}$ it is not the plot one would expect if decreasing case age were leading to higher appeal rates. We can reduce the heteroscedasticity by eliminating all of the data points that

273. The BIA database contains fields for the BIA's decision date and the "NTA" date, the latter of which appears to be the date of the Notice to Appear used to initiate removal proceedings or the comparable notice used to initiate pre-IIRIRA exclusion or deportation proceedings.

274. Heteroscedasticity refers to the variance of the random error term in a regression model. One of the assumptions in making predictions using least squares regression is that the variance of the error term remains roughly the same for every value of our independent variables. The extent to which data deviate from this assumption is called heteroscedasticity, and too much heteroscedasticity makes it impossible for us to make accurate predictions using a least squares regression model. See generally William Mendenhall \& Terry Sincich, A SeCond Course in STATistics: Regression ANALYSIS 342, 379-91 (6th ed. 2003).

In the data we present here, the heteroscedasticity is presumably caused by the fact that rate of appeal is a binomial proportion, and as such, its variance is a function of both the true proportion and the sample size. However, we have been unable to correct for this using standard variance stabilizing functions, such as $y^{\prime}=1 / 2\left(\sin ^{-1} \sqrt{x /(n+1)}+\sin ^{-1} \sqrt{(x+1) /(n+1)}\right)$ (where $n$ is the sample size for each interval and $x$ is the number of BIA decisions in that interval that were challenged in petitions for review), see Murry F. Freeman \& John W. Tukey, Transformations Related to the Angular and the Square Root, 21 Annals Mathematical Stats. 607 (1950); Frederick Mosteller \& Cleo Youtz, Tables of the Freeman-Tukey Transformations for the Binomial and Poisson Distributions, 48 BIOMETRIKA 433 (1961); or $y^{\prime}=\sin ^{-1} \sqrt{y}$, see SNEDECOR \& COCHRAN, supra note 205, at 289-90. 
Figure 7: APPEAL RATE VERSUS 180-DAY AGE INTERVAL

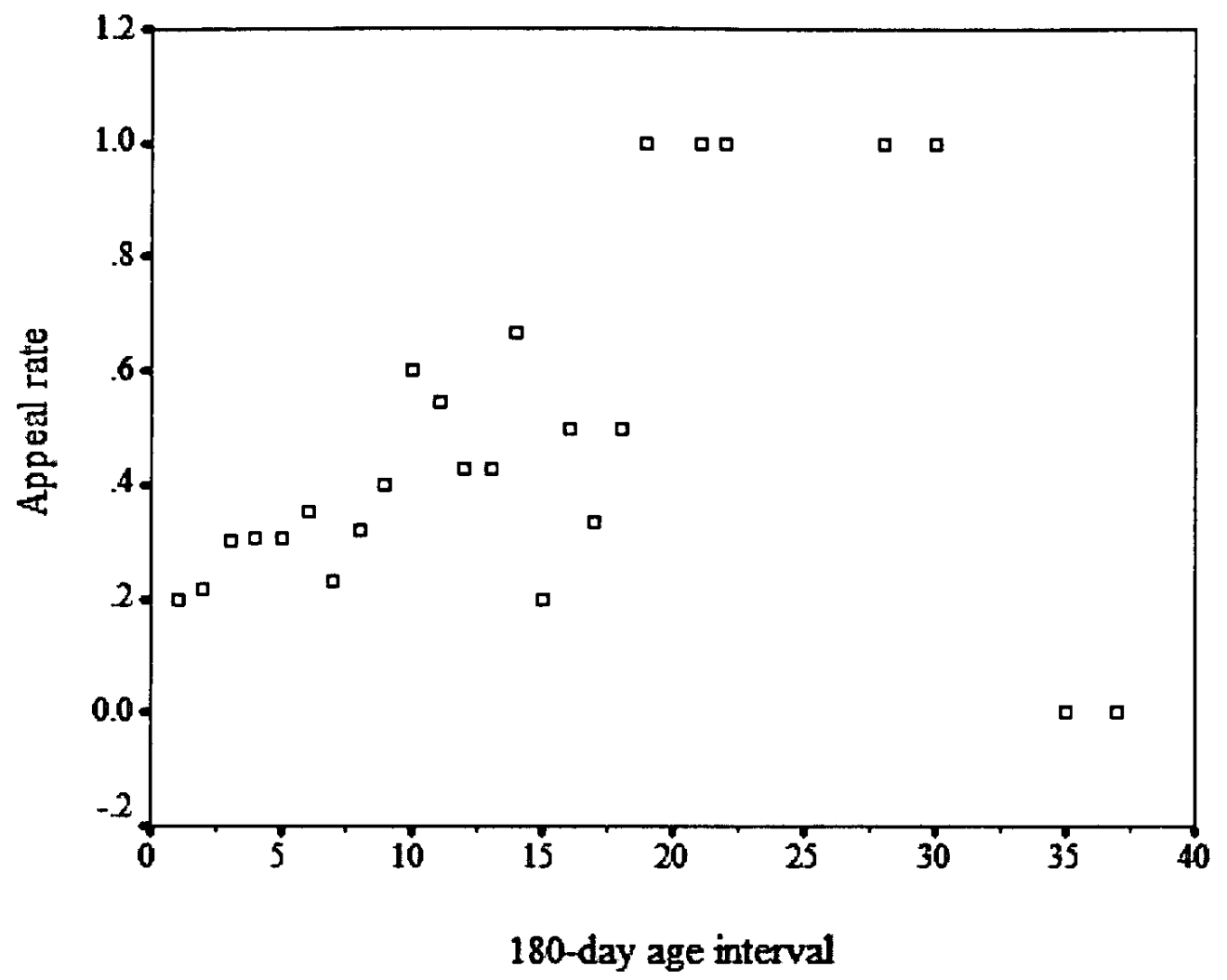

Source: Random sample of BIA decisions issued between May 1 and August 31, 2004, in direct appeals from IJs and courts of appeals docket databases. See supra Part III.E.3.

are based on less than six decisions (i.e. by eliminating the point for interval number 1 and all of the points above interval number 14, as shown in Table 5 ). We can then calculate the least squares regression line for the remaining data points; it has a slope of 0.029 petitions for review per BIA decision per 180-day age interval. (See Figure 8.) The model accounts for about $61 \%$ of the variation observed in the appeal rate $\left(R_{a d j u s t e d}^{2}=0.612\right)$, and the significance levels for the global F-test as well as the t-test of our slope parameter are both approximately 0.001 .

While our data suggest that any correlation between case age and appeal rate is the opposite from the correlation predicted under the EOIR's theory, we need to be careful about any conclusions we draw. As with the data on summary procedures, any conclusions must be limited to the time period at which we looked. Similarly, our regression analysis can be used to make predictions only about case ages that fall within the range for which we have data points (i.e., from about 0.5 to seven years). Even if there is a positive correlation between age and appeal rate within the range of ages in our sample, the relationship could change if we expanded our $\mathrm{x}$-axis to include older cases. 
TABLE 5: APPEAL RATE VERSUS 180-DAY AGE INTERVAL

\begin{tabular}{|c|c|c|c|}
\hline $\begin{array}{c}180-\text { day } \\
\text { age interval }\end{array}$ & $\begin{array}{c}\text { Total \# BIA } \\
\text { decisions }\end{array}$ & $\begin{array}{c}\text { Number of } \\
\text { BIA decisiosn } \\
\text { challenged in } \\
\text { petitions for review }\end{array}$ & $\begin{array}{c}\text { Appeal rate ([\#BIA } \\
\text { decisions challenged in } \\
\text { petitions for review]/ } \\
\text { [Total \# BIA decisions]) }\end{array}$ \\
\hline 1 & 5 & 1 & 0.20 \\
\hline 2 & 23 & 5 & 0.22 \\
\hline 3 & 10 & 3 & 0.30 \\
\hline 4 & 62 & 19 & 0.31 \\
\hline 5 & 92 & 28 & 0.30 \\
\hline 6 & 82 & 29 & 0.35 \\
\hline 7 & 48 & 11 & 0.23 \\
\hline 8 & 25 & 8 & 0.32 \\
\hline 9 & 20 & 8 & 0.40 \\
\hline 10 & 10 & 6 & 0.60 \\
\hline 11 & 11 & 6 & 0.55 \\
\hline 12 & 7 & 3 & 0.43 \\
\hline 13 & 7 & 3 & 0.43 \\
\hline 14 & 6 & 4 & 0.67 \\
\hline 15 & 5 & 1 & 0.20 \\
\hline 16 & 2 & 1 & 0.50 \\
\hline 17 & 3 & 1 & 0.33 \\
\hline 18 & 2 & 1 & 0.50 \\
\hline 19 & 1 & 1 & 1.00 \\
\hline 21 & 1 & 1 & 1.00 \\
\hline 22 & 1 & 1 & 1.00 \\
\hline 28 & 1 & 1 & 1.00 \\
\hline 30 & 2 & 2 & 1.00 \\
\hline 35 & 1 & 0 & 0.00 \\
\hline 37 & 1 & 0 & 0.00 \\
\hline Total & 428 & 144 & 0.34 \\
\hline
\end{tabular}

Source: Random sample of BIA decision issued between May 1 and August 31, 2004 , in direct appeals from IJs and courts of appeals docket databases. See supra Part III.E.3.

There are, however, a number of reasons to think that older cases would generally be appealed at a higher rate than younger ones, notwithstanding the existence of certain aliens willing to stop litigating after a given period of 
FIGURE 8: LEAST SQUARES REGRESSION OF APPEAL RATE AS A FUNCTION OF CASE AGE

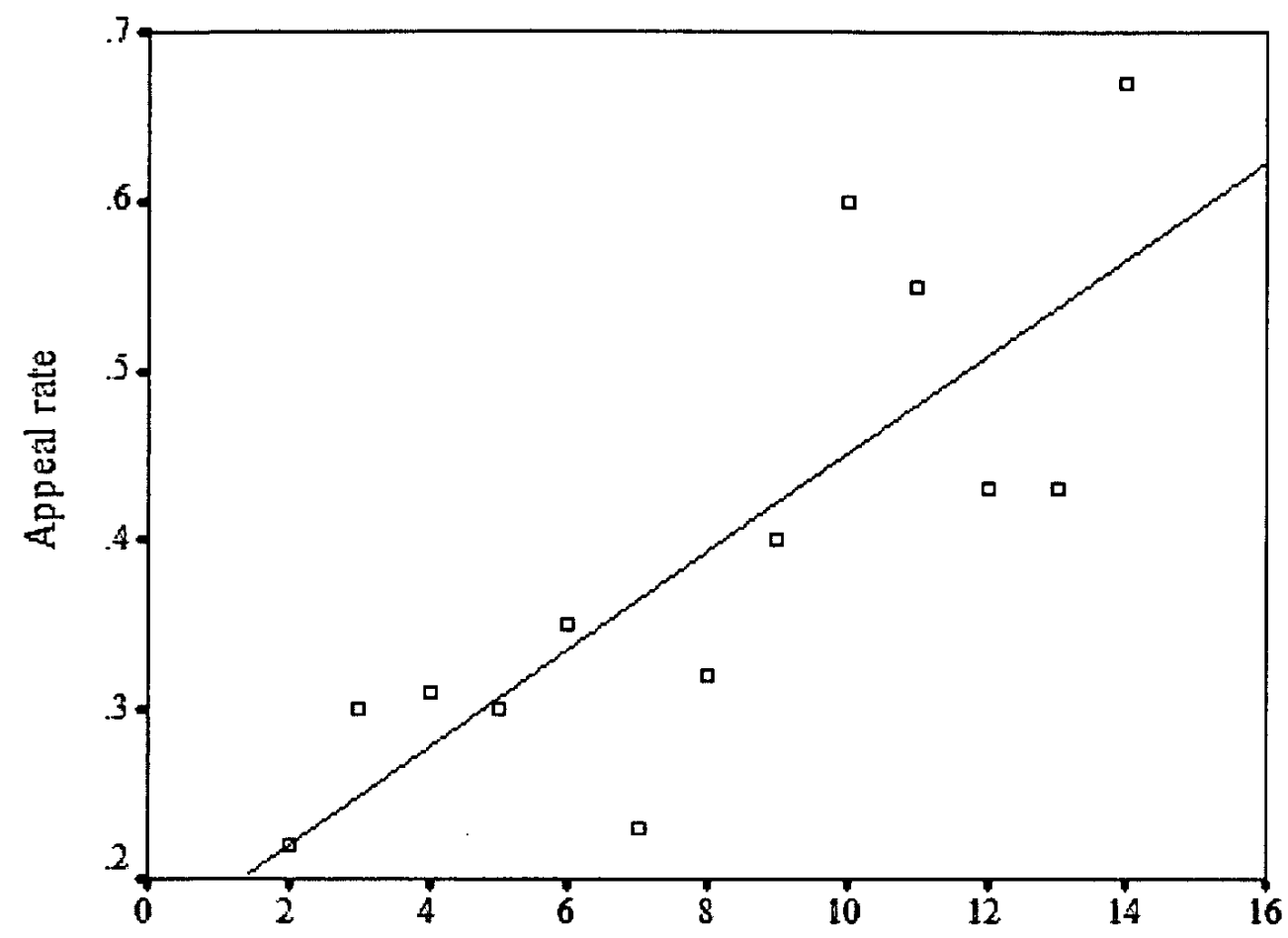

180-day age interval

Source: Random sample of BIA decisions issued between May 1 and Aug. 31, 2004 , in direct appeals from IJs, and courts of appeals docket databases. See supra Part III.E.3.

Note: Data points based on less than six observations have been omitted.

time. First, the longer administrative delay in an old case may result from aggressive litigation, and this may reflect the fact that the alien in question has the will and resources to exhaust his or her options and continue litigating aggressively until the end. Second, the longer administrative delay may have resulted from the existence of a genuinely difficult case. This complexity may mean that there are stronger grounds for filing a petition for review. Third, and perhaps most significantly, the longer an individual spends in litigation at the administrative level, the more ties that person is likely to have formed in this country, and therefore, the more incentive that person may have to exhaust all possibilities in an attempt to remain in this country.

\section{Substantive Issues and Expulsion Costs}

Thus far, we have considered characteristics that relate fairly directly to the BIA's procedures. These factors seem like the most obvious candidates for explaining the increased appeal rate, but there are a host of other 
characteristics that could be important as well. While some of these other factors are less clearly linked to the 2002 procedural changes, there are reasons to suspect that their prevalence within the pool of BIA decisions may have been at least indirectly effected. Moreover, these characteristics could help account for the variation in the appeal rate among the different circuits, a phenomenon that our other variables have so far failed to address. We begin by looking at the substantive issues raised on appeal to the BIA and the expulsion costs faced by the aliens whose appeals the BIA is deciding. We treat these variables together because we used one sampling operation to make estimates about them.

Consider, first, the substantive issues implicated in a BIA decision. During the time period in question, jurisdictional bars prevented litigants from challenging many issues in petitions for review. ${ }^{275}$ Other issues could have been challenged, but such challenges were unlikely to succeed. We should therefore expect to see differences in the rate of appeal among groups of BIA decisions that hinge on different issues. We should find, for example, that discretionary denials of cancellation of removal are rarely appealed because of the jurisdictional bar. Conversely, discretionary denials of asylum might be appealed somewhat more frequently, and denials of asylum based on the eligibility criteria might be appealed even more frequently.

There are good reasons to think that the proportions of various substantive issues implicated in the pool of BIA decisions changed after March 2002. The most obvious reason is that the BIA expanded its use of summary procedures at that time by adding new categories of cases to which these procedures could be applied. Significantly, on March 15, 2002, the BIA added a general category for asylum and withholding claims. ${ }^{276}$ Because the stated purpose of summary procedures is to decide more cases in less time, ${ }^{277}$ the proportion of asylum, withholding, and CAT claims likely increased once they became eligible for streamlining.

In addition, consider the costs that a particular alien incurs if he or she is expelled from the United States. Expulsion costs can encompass a wide variety of losses, deprivations, and suffering. ${ }^{278}$ These may relate purely to what will happen in the alien's country of origin, and may be enormous for

\footnotetext{
275. See supra notes 103-107.

276. See Memorandum, supra note 144; supra note 145 and accompanying text.

277. See 64 Fed. Reg. 56,135-36; 67 Fed. Reg. 54,878.

278. James Madison famously summed up many of these costs in arguing against the Alien and Sedition Act:
}

If banishment of an alien from a country into which he has been invited as the asylum most auspicious to his happiness, - a country where he may have formed the most tender connections; where he may have invested his entire property, and acquired property ...; where he enjoys, under the laws, a greater share of the blessings of personal security, and personal liberty, than he can elsewhere hope for; and where he may have nearly completed his probationary period of citizenship; if, moreover, in the execution of the sentence against him, he is to be exposed, not only to the ordinary dangers of the sea, but to the peculiar casualties incident to a crisis of war and of unusual licentiousness on that element and possibly to vindictive purposes, which his emigration itself may have provoked; -if a banishment of this 
those fleeing persecution or other serious harm. Costs may also relate to the size of the gap between the United States and the country of origin in terms of quality of life and economic prospects. They may relate to the loss of family and friends, as well as property and investments in the United States. Finally, they may relate to the costs that the person incurred in coming to the United States and the costs that he or she would incur in trying to return after being expelled. ${ }^{279}$ All of these costs are important because people with more to lose are likely to challenge BIA decisions at a higher rate than others. ${ }^{280}$

The costs of being expelled might seem like an odd characteristic by which to sub-divide the pool of BIA decisions, as they hinge on a host of external variables. Nonetheless, we might see changes in the proportion of BIA decisions involving people with high expulsion costs for the same reasons that we see changes in the proportions of decisions with other characteristics. While the BIA is not likely to consciously select from its pool of pending cases based on expulsion cost, it might select based on a particular type of claim or a particular country of origin. This selection could unintentionally entail a selection according to expulsion costs.

For example, by selecting Chinese asylum claims, the BIA would likely end up with a large number of people from Fujian Province who: (1) paid enormous smuggling fees and endured brutal treatment in order to come to the United States, (2) may still be in debt as a result, (3) are making significantly more money here than they could make in their country of

sort be not punishment, and among the severest of punishments, it will be difficult to imagine a doom to which the name can be applied.

Madison's Report on the Virginia Resolutions, 4 Elliot's Debates 555, available at http:// memory.loc.gov/cgi-bin/query/r?ammem/hlaw:@field (DOCID+ @lit (ed00499)) (last visited May 9, 2005); see also Fong Yue Ting v. United States, 149 U.S. 698, 744-61 (1893) (Field, J., dissenting); United States v. Restrepo, 802 F. Supp. 781, 790 (E.D.N.Y. 1992), vacated by 999 F.2d 640 (2d Cir. 1993).

279. Many people spend their lives' fortunes-and often their relatives' lives' fortunes-to come to the United States. Returning after being expelled may be financially impossible (leaving aside the legal obstacles). Moreover, the monetary costs are often just part of the sacrifice: many people who are smuggled here endure arduous journeys; many are threatened and physically abused by their smugglers (or by people associated with their smugglers). Both the high monetary costs and high personal costs appear to be particularly common among the people smuggled to New York from China's Fujian Province. See generally CHIN, supra note 24; KwoNG, supra note 24; Joyce Purnick, Snakeheads That Bite and Hang On, N.Y. Times, Apr. 14, 2005, at B 1; Amy Zimmer, Journey to the Golden Mountain, CiTY LiMITS, Jan. 1, 2004, at 26. In contrast, other people incur much smaller costs in coming here and may be able to return relatively easily even if they are expelled. See, e.g., U.S. Gen. Accounting Office, Alien Smuggling: Management and Operational Improvements NEEDED to ADDRESS GROWING PROBLEM (May 2000) (reporting that smuggling fees "can range from a few hundred dollars to cross the U.S. border to up to $\$ 50,000$ to be smuggled from China", available at http://www.gao.gov/new.items/gg00103.pdf.; David KYLE \& ZaI LianG, Migration MERChanTs: Human SMUggling FROM ECUADOR AND ChINA (Center for Comparative Immigration Studies Working Paper No. 43, October 2001).

280. This proposition is similar to the "investment" hypothesis discussed in Schuck \& Wang, supra note 11 , at $134 \& \mathrm{n} .88$. That hypothesis predicts that people who must invest a lot in migrating to the United States will do so only if they have strong claims to be able to stay and that if they are placed in expulsion proceedings, they will invest even more to vindicate these claims. See id. The Schuck \& Wang study, however, did not find evidence to support this hypothesis and in fact found some evidence that tended to refute it. See id. at 135. 
origin, and (4) face the prospect of being returned to an authoritarian, one-party state that officially restricts many of their rights and may punish them for having departed illegally. ${ }^{281}$ Even to the extent that these people are unable to succeed on their asylum claims, their expulsion costs are so high that they are likely to appeal at a high rate regardless.

We lack time-series data on changes in the proportion of substantive issues and expulsion costs within the pool of BIA decisions. ${ }^{282}$ However, we have made some rough estimates of the differences in these proportions for BIA decisions arising within the Second, Ninth, and Eleventh Circuits. We can then compare these estimates to the appeal rates for each circuit, which we calculated in Table 1 above. If differences in substantive issues and expulsion cost can explain the inter-circuit differences in appeal rate, then perhaps they can also explain the increase in appeal rate since March 2002.

For each circuit, we took a random sample of 100 BIA decisions that were issued between May 1 and August 31, 2004, in direct appeals from IJs who had completed proceedings in that circuit. We then examined each of these decisions and, where available, the underlying IJ decisions, and we recorded (1) whether the alien had claimed asylum, withholding, and/or CAT relief, (2) whether the decision resulted in a final order of removal (or at least an alternate final order of removal accompanying a grant of voluntary departure), and (3) the alien's country of origin. ${ }^{283}$

We recognize, from the outset, that asylum and country of origin are crude, overly broad categories with which to make generalizations about the diverse array of substantive issues and expulsion costs involved in these cases. Although one might generalize that people who travel to the United States from more distant countries of origin invest more in coming here than those who travel from closer ones, ${ }^{284}$ this probably does not hold true for many countries of origin. In fact, it may not hold true for any, given that actual travel costs are only one part of the equation. In addition, one might generalize that people from closer countries also face lower costs in returning to the United States after being expelled, but we must still factor in such legal hurdles as bars to reentry and criminal penalties for reentering without authorization.

We present our findings in Tables 16, 17, and 18 of the Appendix. As these tables show, we found substantial variation in the composition of BIA decisions arising within each of the circuits we sampled. The pool of Second Circuit BIA decisions is dominated by asylum claims, and the majority of the

281. See, e.g., U.S. Department of State, Country Reports on Human Rights Practices2004 (Feb. 28, 2005), available at http://www.state.gov/g/drl/rls/hrrpt/2004/41640.htm. See generally CHIN, supra note 24; KWONG, supra note 24.

282. Although it does not help us in explaining the dynamics of 2002, the Schuck \& Wang study, supra note 11 , at 142-45, presented a very interesting set of data on changes over time, during the 1980 's, in the substantive immigration issues raised in federal courts.

283. See supra Part III.E.3.

284. See Schuck \& Wang, supra note 11, at 134. 
asylum claims are filed by people from China. We can estimate with $95 \%$ confidence that final orders of removal against Chinese asylum-seekers make up between $35 \%$ and $55 \%$ of the population of BIA decisions from which we drew our Second Circuit sample. ${ }^{285}$

In contrast, the Eleventh Circuit is dominated by asylum claims, but they are mostly brought by people from Colombia and Haiti. We can estimate with 95\% confidence that final orders of removal against Colombian and Haitian asylum-seekers each make up between $27 \%$ and $47 \%$ of the population of BIA decisions from which we drew our Eleventh Circuit sample and that these groups combined make up between $68 \%$ and $83 \% .^{286}$

Finally, the Ninth Circuit is more evenly split between decisions that do and do not involve asylum claims. In addition, no single nationality dominates the decisions involving asylum claims, whereas Mexicans dominate the decisions that do not involve asylum claims. We can estimate with $95 \%$ confidence that final orders of removal against Mexicans who raised no asylum claim make up between $27 \%$ and $47 \%$ of the population from which we drew our sample and that final orders against asylum-seekers from scattered countries make up between $18 \%$ and $36 \% .^{287}$

With regard to substantive issues, these data are somewhat perplexing. Recall that the Ninth Circuit's appeal rate was 45\%, the Second Circuit's was $42 \%$, and the Eleventh Circuit's was $9 \%$. If the proportion of asylum claims is driving these differences, it would appear, if anything, to be decreasing appeal rate more than increasing it. This seems unlikely given the jurisdictional bars faced in other types of claims. It is more likely that the differences in appeal rate are simply being driven by some other variable. This does not rule out the possibility that an increase in the proportion of asylum claims within the pool of BIA decisions nationwide contributed to the overall increase in appeal rate in 2002 . It simply means that we cannot support such a theory with the data we have.

Our data with regard to expulsion costs are also perplexing. If we assume that expulsion costs are linked to country of origin and that they increase with distance from the United States, then expulsion costs might explain the difference between the appeal rates in the Second and Eleventh Circuits. The Ninth Circuit, however, does not fit the pattern. The Second Circuit's Chinese asylum-seekers presumably have high expulsion costs and may be prone to litigate for that reason. Although we would hesitate before concluding that the costs of being expelled to Haiti or Colombia are low, we might speculate that they are lower than the costs of being expelled to China, simply based on distances. The problem, however, is that the Ninth Circuit has a high appeal

285. We reach these estimates using the formula: $\hat{p} \pm[1.96 \sqrt{\hat{p} \hat{q} / n}+1 /(2 n)]$, which includes a correction for continuity. See SNEDECOR \& COCHRAN, supra note 205, at 121.

286. On the formula for these estimates, see supra note 285.

287. On the formula for these estimates, see supra note 285. 
rate, but also a high proportion of final orders of removal involving people from the Americas. Perhaps the dynamics in the Ninth Circuit are unique, or perhaps our assumptions about expulsion costs are simply inaccurate. It may be, for instance, that reentry bars and other civil and criminal consequences of expulsion are so high as to overshadow the differences between countries of origin in travel costs. ${ }^{288}$ Finally, there may simply be some other variable at play that overshadows expulsion costs as a factor altogether.

We obviously need more information before we can draw any conclusions. For one thing, it would be useful to look at the composition of each circuit's docket to see which groups of BIA decisions are actually being challenged. We did this for the Second Circuit, by examining a random sample of 189 petitions for review that were pending on the court's docket as of April 12, 2005 , and for which records had been filed before January $2005 .{ }^{289}$ As shown in Table 19 of the Appendix, we found that 107 of these petitions were brought by people from China, and from that we estimate with $95 \%$ confidence that between $49 \%$ and $64 \%$ of the total population from which we drew the sample consists of petitions brought by people from China. ${ }^{290}$ Although there is a large margin of error in all of our estimates and much information is lacking, the data do not support a theory that people from China bring petitions for review at a higher rate than people from other countries. It would be very interesting to examine the composition of pending cases in the Ninth and Eleventh Circuits, but we leave this for a future study.

\section{Detention}

A variable that might better explain the observed inter-circuit differences in appeal rate, and thus might be useful in explaining changes over time, is whether or not the alien in question is detained. BIA decisions involving detained aliens are probably appealed at a lower rate than other decisions for three reasons. First, people who are detained are likely inhibited from filing petitions for review because it is more difficult for them to locate, afford, and meet with counsel. In addition, many of the detainees who are unable to obtain counsel have a more difficult time preparing their cases pro se. ${ }^{291}$

288. The significance of these civil and criminal consequences of expulsion was stressed to us by Charles Roth, at the Midwest Immigrant \& Human Rights Center, who pointed out, for instance, that Mexicans seeking to maintain family unity may have just as high expulsion costs as Chinese asylum seekers. E-mail to Stephen W. Yale-Loehr (Sept. 4, 2005, 10:25 MT) (on file with authors).

289. See supra Part III.C.

290. On the formula for these estimates, see supra note 285.

291. See Ruth Ellen Wasem, U.S. Immigration Policy on Haitian Migrants 6 (Congressional Research Service Jan. 21 , 2005) [hereinafter HaITIAN MIGRANTs], available at http://ndu.edu/library/ docs/crs/crs_rs21349_21jan05.pdf (last visited May 15, 2005); The Detention and Treatment of Haitian Asylum Seekers: Hearing Before the Senate Comm. on the Judiciary, Subcomm. on Immigration, 107th Cong. 11 (2002) (statement of Cheryl Little, Exec. Director, Florida Immigrant Advocacy Center) [hereinafter Little Testimony]. In this regard, a study by Georgetown University 
Second, detained aliens are probably more likely than non-detained aliens to have been convicted for crimes that trigger jurisdictional bars to filing petitions for review. ${ }^{292}$ To the extent that this is so, it obviously implicates the substantive issues variable discussed above. Third, people in detention may be less inclined than others to file petitions for review since the effect of such petitions is often to prolong their detention. ${ }^{293}$

Detention could account for the Eleventh Circuit's low appeal rate because its high proportion of Haitian asylum-seekers probably means that it has a high proportion of detained aliens. Whereas inadmissible asylum-seekers from other countries are often detained briefly but ultimately released while their asylum claims are adjudicated, inadmissible Haitians are currently detained, as a matter of policy, even after they have been found to have credible fears of persecution. ${ }^{294}$ Moreover, many of the concerns raised over detained aliens' access to counsel have specifically focused on the experience of detained Haitians in Florida. ${ }^{295}$ In contrast, the pools of BIA decisions arising in the Second and Ninth Circuits have much smaller proportions of Haitians, and probably smaller proportions of detained aliens. ${ }^{296}$

If detention helps to explain inter-circuit differences in appeal rate, perhaps it also helps to explain the increase in appeal rate in March 2002. In fact, the EOIR reports that the proportion of BIA decisions involving detained aliens decreased in 2002. As Table 6 shows, the proportion of BIA decisions involving detained aliens in appeals taken directly from IJ decisions ranged from $19 \%$ to $38 \%$ between fiscal years 1996 and 2001. Between fiscal years 2002 and 2004, that number ranged from $12 \%$ to $14 \%$. Presumably, this is not because fewer people are being detained, but because the BIA increased its output by deciding mostly non-detainee cases. This would make

suggests that asylum-seekers in detention are more than twice as likely as non-detained asylum seekers to be unrepresented. Andrew I. Schoenholtz \& Jonathan Jacobs, The State of Asylum Representation: Ideas for Change, 16 GEO. IMMIGR. L.J. 739, 748-49 \& n.68, 772 tbl.8 (2002).

292. See supra notes 60,103 and accompanying text.

293. Although many aliens may prefer the conditions of U.S. detention facilities to what they would face in their countries of origin, see, e.g., In re J-E-, 21 I. \& N. Dec. 291 (BIA 2002), there have also been a number of extremely disturbing reports on the treatment of aliens detained in the United States. See generally, MARK Dow, AMERICAN GULAG (2004).

294. Ruth Ellen Wasem, U.S. Immigration Policy on Asylum Seekers 20-2 1 (Congressional Research Service Feb. 16, 2005), available at http://www.fas.org/sgp/crs/misc/RL32621.pdf; HAITIAN Migrants, supra note 291, at 4-5; HuM. RTS. FIRST, IN LIBERTY's SHADOW: U.S. DeTENTION OF ASYlum SeEkERS IN THE ERA OF HOMELAND SECuRITy 22-23 (2004), available at http:// www.humanrightsfirst.org/asylum/libertys_shadow/Libertys_Shadow.pdf.

295. See Little Testimony, supra note 291; HaITIAN MIGRANTS, supra note 291, at 6.

296. With regard to the Second Circuit's large pool of Chinese asylum seekers, we note that a study of EOIR data showed that of the Chinese asylum seekers in Immigration Court in fiscal year $1999,96 \%$ of those who filed defensive asylum applications and $90 \%$ of those who filed affirmative asylum applications were represented by counsel. Schoenholtz \& Jacobs, supra note 291, at 767 tbl.3. The study also showed that $85 \%$ of the Haitians who filed defensive applications and $62 \%$ of those who filed affirmative applications were represented by counsel. Id. However, this was before the new detention policy for Haitians went into effect, so we would presume that those numbers are much lower today. 
sense, given that the BIA already treated detainee cases on a priority basis, ${ }^{297}$ and it therefore may have quickly exhausted its supply of such cases. ${ }^{298}$ Whatever the reason, however, the increase in the proportion of non-detained aliens within the pool of BIA decisions might very well account for at least some of the increase in appeal rate.

TAble 6: AnNual number AND PERCENTAGE of BIA DECisions INVOlVing DETAINED ALIENS

\begin{tabular}{|c|c|c|}
\hline $\begin{array}{c}\text { Fiscal } \\
\text { Year }\end{array}$ & $\begin{array}{c}\text { Total number of BIA } \\
\text { decisions in appeals taken } \\
\text { directly from IJs }\end{array}$ & $\begin{array}{c}\text { Number (and percentage) } \\
\text { of those BIA decisions } \\
\text { that involved detained aliens }\end{array}$ \\
\hline 1996 & 10,494 & $2,404(23 \%)$ \\
\hline 1997 & 14,496 & $2,963(20 \%)$ \\
\hline 1998 & 20,291 & $3,926(19 \%)$ \\
\hline 1999 & 15,942 & $5,030(32 \%)$ \\
\hline 2000 & 12,935 & $4,884(38 \%)$ \\
\hline 2001 & 20,566 & $4,438(22 \%)$ \\
\hline 2002 & 34,254 & $3,961(12 \%)$ \\
\hline 2003 & 32,313 & $3,845(12 \%)$ \\
\hline 2004 & 31,583 & $4,317(14 \%)$ \\
\hline
\end{tabular}

Source: EOIR statistical yearbooks. ${ }^{299}$

Note: The data is limited to BIA decisions in appeals from IJ proceedings.

This does not suggest that the solution to the immigration surge is to keep more aliens in detention. To the extent that jurisdictional bars are behind the lower appeal rate for detained aliens, detention itself should not make a difference, since it is the criminal convictions themselves that trigger the bars. To the extent that fear of prolonged detention, lack of access to counsel, and other difficulties in preparing appeals are the critical factors, detaining

297. See, e.g., EOIR YB 2004, supra note 7, at X1.

298. See E-mail from Professor Stephen H. Legomsky, Charles F. Nagel Professor of International and Comparative Law, Washington University in St. Louis School of Law, to John R.B. Palmer (Aug. 12, 2005, 07:50:55 MT) (on file with authors) (speculating that this might have been the cause).

299. The data for fiscal years 2000 through 2004 are taken from EOIR YB 2004, supra note 7, at $\mathrm{X} 1$. The data for fiscal year 1999 are taken from EOIR YB 2003, supra note 193, at X1. The data for fiscal year 1998 are taken from EOIR, OfFICE OF PLANNING ANd ANALYSIS, STATISTICAL YEAR BoOK $2002 \mathrm{Wl}$ (Apr. 2003), available at http://www.usdoj.gov/eoir/statspub/fy02syb.pdf. The data for fiscal year 1997 are taken from EOIR, OfFice of PlanNing ANd ANALYSIS, FY STatistical Year BOOK $2001 \mathrm{Vl}$ (Mar. 2002) [hereinafter EOIR YB 2001], available at http://www.usdoj.gov/eoir/ statspub/FY01 syb.pdf. The data for fiscal year 1996 are taken from EOIR, OFFICE OF PLANNING AND ANALYSIS, STATISTICAL YEAR BOOK 2000 V1 (Jan. 2001) [hereinafter EOIR YB 2000], available at http://www.usdoj.gov/eoir/statspub/SYB2000Final.pdf. There is some variation between the yearbooks in the numbers reported for certain fiscal years. We assume this difference is due to corrections, and that the most recently reported figures are the most accurate. 
more aliens as a way to decrease appeal rate would be immensely unjust. Indeed, the extent to which these factors already affect appeal rate raises serious concerns about the number of aliens currently detained-and particularly about the policy of detaining Haitian asylum-seekers.

\section{B. BIA Characteristics}

In addition to changes in the composition of the pool of BIA decisions, certain characteristics of the BIA, the courts of appeals, the immigration bar, and the litigants themselves may have been responsible for the overall increase in appeal rate. Although we list these four entities separately, changes in each entity could well have influenced changes in others. For instance, changes in the BIA could have led to changes in the courts of appeals. Furthermore, the changes we discuss in the BIA (other than the compositional changes discussed above) and in the courts of appeals could have only influenced appeal rate by causing changes within the immigration bar and the litigants, who must decide, in each case, whether to file a petition for review.

In exploring the characteristics that may be influential, we assume that each sub-group of BIA decisions could be affected to a different extent, but we look mainly at the broad sub-group of BIA decisions that leave aliens with final orders of removal. We start by exploring BIA characteristics that might influence this sub-group's appeal rate.

\section{Streamlining and Downsizing}

We have already explored the possibility that the sub-group of BIA decisions involving summary procedures might be appealed at a higher rate than other decisions. Another possibility, however, is that the BIA's expansion of summary procedures, combined with the manner in which the BIA was downsized, caused litigants to appeal all final orders of removal at a higher rate. We have already discussed the criticism leveled at the BIA's implementation of streamlining and downsizing. ${ }^{300}$ The immigration bar is generally dissatisfied with the review it is receiving from the BIA, ${ }^{301}$ and immigration lawyers may therefore be more prone to encourage their clients to seek review of any adverse BIA decisions in the courts of appeals. We consider this proposition below in Part V.D.

\section{Volume of BIA Decisions}

Another possibility is that the increase in the volume of BIA decisions also caused a shift in the immigration bar, such that there is now a greater capacity

300. See supra Part II.C.4.

301. See id. 
to litigate in the courts of appeals. That there was a large increase in volume is clear from the data presented above in Part IV.B. The possible shift in the immigration bar is discussed below in Part V.D.

\section{Circuit Court Characteristics}

The fact that appeal rates differ among the circuits suggests that there might be something about the circuit courts themselves behind this disparity. We guess that the two most likely characteristics would be: (1) reversals and settlements and (2) delay.

\section{Reversals and Settlements}

We have already looked at reversals and settlements for BIA decisions nationwide, but we now look more closely at how those decisions fared in the Second, Ninth, and Eleventh Circuits. We used the Administrative Office data to calculate these numbers and rates of reversal and settlement, on an annual basis, since 1994. We started with the number of petitions for review filed in a given year, tracking how many of those were subsequently reversed, vacated, and/or remanded on the merits, in whole or in part ("reversals"), and how many were subsequently settled and/or dismissed pursuant to Federal Rule of Appellate Procedure 42(b) ("settlements"). Using these numbers, we calculated the reversal and settlement rates for the cohorts of petitions for review filed each year from 1994 though 2003, and then also for the first nine months of 2004 (which is where our data end). For the most recent cohorts, it must be kept in mind that a large proportion of the petitions are still pending, which artificially lowers our calculated rates. ${ }^{302}$

Our data, which we present in Tables 7 through 9, show striking differences between the circuits. Leaving aside the most recent cohorts, for which our rate calculations are unreliable, the Ninth Circuit has had a higher reversal rate than the Second and Eleventh Circuits for almost every year since 1994. In fact, the only year for which the Ninth Circuit's reversal rate was not the highest of the three was 1997, but that is because the Eleventh Circuit remanded so many of the $N-J-B$ - challenges filed that year. ${ }^{303}$

The Ninth Circuit's high reversal rate may result from the fact that it tends to scrutinize administrative fact-finding more closely than do other circuits. ${ }^{304}$ Furthermore, while the BIA maintains a policy of intra-circuit acquiescence to court of appeals decisions, ${ }^{305}$ it may be resisting applying the

\footnotetext{
302. See supra note 257 and accompanying text.

303. See supra note 229 and accompanying text. Our data, thus, support the "conventional wisdom" that the Ninth Circuit is more sympathetic to aliens' claims-particularly asylum claimsthan any of the other circuits. See Schuck \& Wang, supra note 11, at $120 \mathrm{n} .23$. This was also found by the Schuck \& Wang study of immigration litigation in the 1980's. See id. at 168-70.

304. See ALEINIKOFF ET AL., supra note 21 , at 977.

305. See, e.g., In re K-V-D-, 22 1. \& N. Dec. 1163, 1170-71 (BIA 1998); Gerald L. Neuman, Federal Court Issues in Immigration Law, 78 TEX. L. REV. 1661, 1681 n.123 (2000).
} 
Ninth Circuit's standards to its own review of IJ decisions because it disagrees with those standards. ${ }^{306}$ This could certainly result in a steady stream of reversible decisions and therefore a steady stream of petitions for review. ${ }^{307}$

Another striking difference we see in Tables 7 through 9 is that the Second Circuit has had a consistently higher settlement rate than the Ninth and Eleventh Circuits. This may result from the fact that the Second Circuit is the only one of the courts of appeals that includes immigration cases in its mediation program. It is unclear, however, whether the Second Circuit's high settlement rate has had an effect on appeal rate, because we do not have complete data on the terms of these settlements. We are therefore unable to estimate the extent to which aliens are obtaining relief through settlements or simply withdrawing their appeals. To the extent that settlements are favorable, aliens could be appealing at a high rate because they are achieving such settlements. To the extent that settlements are simply withdrawals, aliens could be settling at a high rate because their lawyers are appealing at such a high rate that they do not have time to evaluate their chances of success in each case until after they have already filed it.

Leaving aside inter-circuit differences, the more important question for the purposes of our inquiry is whether any of this helps to explain the overall increase in appeal rate starting in 2002. We do not see anything to suggest that it does. While one might imagine that an increase in reversal or settlement rates in 2000 or 2001 could have encouraged people to file more petitions for review, we do not see such increases in Tables 7 through 9. Of course, these tables focus on the year in which a cohort of petitions for review were filed, whereas what may be more important to litigants are the years in which courts issue decisions reversing the BIA. In Table 10 we therefore calculate the proportion of reversals in the group of cases terminated in each given year. Still, however, we do not see the type of increase that we imagine could have sparked a surge in filings. There is a small increase in the Ninth Circuit from about $6 \%$ in 2000 to about $10 \%$ in 2001 and about $11 \%$ in 2002 . We see a similar increase in the reversal and settlement rates reported in Table 8. Comparable reversal rates, however, were seen in 1994 through 1996, and these did not spark the type of surge we have seen since 2002.

306. In the supplemental information to the September 2002 "Procedural Reform" regulation, the Department of Justice cited five Ninth Circuit decisions as examples of how "some courts have failed to defer to administrative factfinding." In addressing whether this might present a problem for the BIA's shift from de novo review to clear error review, the Department wrote that it "disagrees with such an approach [of circuit courts failing to defer to agency factfinding], and therefore does not consider it appropriate to alter the nature of the Board's appellate review to conform to it." 67 Fed. Reg. 54,878, 54,891. Although this obviously does not show that the BIA is ignoring Ninth Circuit standards, it does suggest a certain amount of hostility towards them.

307. For a fascinating discussion of how intra-circuit nonacquiescence by the Social Security Administration created a flood of federal judicial appeals in the 1980's, see Matthew Diller \& Nancy Morawetz, Intracircuit Nonacquiescence and the Breakdown of the Rule of Law: A Response to Estreicher and Revesz, 99 YALE L.J. 801, 817 (1990). 
TABle 7: SECONd CiRCuIt REVERSAL AND SETTLEMENT RATES For PETITIONS FOR REVIEW BY FILING YEAR

\begin{tabular}{|c|c|c|c|c|c|}
\hline \multirow[t]{2}{*}{$\begin{array}{l}\text { Filing } \\
\text { Year } \\
(y)\end{array}$} & \multirow{2}{*}{$\begin{array}{c}\text { Petitions } \\
\text { for review } \\
\text { filed }\end{array}$} & \multicolumn{2}{|c|}{$\begin{array}{l}\text { Petitions for review filed in year y that } \\
\text { were subsequently terminated on the } \\
\text { merits through reversal, vacature, } \\
\text { and/or remand, in whole or in part }\end{array}$} & \multicolumn{2}{|c|}{$\begin{array}{l}\text { Petitions for review filed in year y that were } \\
\text { subsequently settled and/or dismissed under } \\
\text { FRAP } 42(b)\end{array}$} \\
\hline & & $N$ & $\%$ of toral filed & $N$ & $\%$ of total filed \\
\hline 1994 & 109 & 1 & $0.92 \%$ & 28 & $25.69 \%$ \\
\hline 1995 & 105 & 1 & $0.95 \%$ & 40 & $38.10 \%$ \\
\hline 1996 & 90 & 0 & $0.00 \%$ & 26 & $28.89 \%$ \\
\hline 1997 & 184 & 1 & $0.54 \%$ & 118 & $64.13 \%$ \\
\hline 1998 & 287 & 2 & $0.70 \%$ & 182 & $63.41 \%$ \\
\hline 1999 & 290 & 0 & $0.00 \%$ & 165 & $56.90 \%$ \\
\hline 2000 & 189 & 6 & $3.17 \%$ & 97 & $51.32 \%$ \\
\hline 2001 & 168 & 2 & $1.19 \%$ & 92 & $54.76 \%$ \\
\hline 2002 & 994 & St & 0.560 & 3 & $3.3 .30 \%$ \\
\hline 2003 & 2,180 & $x+1$ & $005 \%$ & 178 & $8.17 \%$ \\
\hline 2004 & 2,043 & 20 & $0.000 \%$ & $3 \sqrt{6}$ & $0.41 \%$ \\
\hline Total & 6,639 & 18 & 0.200 & 1266 & 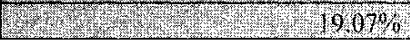 \\
\hline
\end{tabular}

Source: Administrative Office data. See supra Part III.A.

Note: The shaded cells indicate that less than $80 \%$ of the petitions for review filed during that year had been terminated as of September 30,2004, and that the observed proportions are therefore not accurate measures of the actual rates. In addition, the figure for cases filed in 2004 includes only those cases that had been filed by September 30, 2004.

TABle 8: Ninth Circuit Reversal ANd SETtlement Rates FOR PETITIONS FOR REVIEW BY FILING YEAR

\begin{tabular}{|c|c|c|c|c|c|}
\hline \multirow[t]{2}{*}{$\begin{array}{c}\text { Filing } \\
\text { Year } \\
(y)\end{array}$} & \multirow{2}{*}{$\begin{array}{c}\text { Petitions } \\
\text { for review } \\
\text { filed } \\
N\end{array}$} & \multicolumn{2}{|c|}{$\begin{array}{l}\text { Petitions, for review filed in year y that } \\
\text { were subsequently terminated on the } \\
\text { merits through reversal, vacature, } \\
\text { andlor remand, in whole or in part }\end{array}$} & \multicolumn{2}{|c|}{$\begin{array}{l}\text { Petitions for review filed in year y that were } \\
\text { subsequenty settled and/or dismissed under } \\
\text { FRAP 42(b) }\end{array}$} \\
\hline & & $N$ & $\%$ of total filed & $N$ & $\%$ of total filed \\
\hline 1994 & 517 & 57 & $11.03 \%$ & 47 & $9.09 \%$ \\
\hline 1995 & 524 & 65 & $12.40 \%$ & 47 & $8.97 \%$ \\
\hline 1996 & 675 & 51 & $7.56 \%$ & 50 & $7.41 \%$ \\
\hline 1997 & 1015 & 73 & $7.19 \%$ & 69 & $6.80 \%$ \\
\hline 1998 & 1123 & 97 & $8.64 \%$ & 77 & $6.86 \%$ \\
\hline 1999 & 934 & 81 & $8.67 \%$ & 74 & $7.92 \%$ \\
\hline 2000 & 887 & 99 & $11.16 \%$ & 123 & $13.87 \%$ \\
\hline 2001 & 903 & 99 & $10.96 \%$ & 116 & $12.85 \%$ \\
\hline 2002 & 3,649 & 289 & $7.92 \%$ & 461 & $12.63 \%$ \\
\hline 2003 & 4,018 & 16 & $2860 \%$ & 364 & $906 \%$ \\
\hline 2004 & 4,337 & 56 & 0.740 & 69 & $228^{\circ}$ \\
\hline Total & 18,582 & 1032 & $=145550$ & 1527 & 40 \\
\hline
\end{tabular}

Source: Administrative Office data. See supra Part III.A.

Note: The shaded cells indicate that less than $80 \%$ of the petitions for review filed during that year had been terminated as of September 30,2004, and that the observed proportions are therefore not accurate measures of the actual rates. In addition, the figure for cases filed in 2004 includes only those cases that had been filed by September 30, 2004. 
Table 9: Eleventh Circuit ReVersal And SETtlement Rates For PETItions FOR REVIEW BY FILING YEAR

\begin{tabular}{|c|c|c|c|c|c|}
\hline \multirow[t]{2}{*}{$\begin{array}{l}\text { Filing } \\
\text { Year } \\
\text { (y) }\end{array}$} & \multirow{2}{*}{$\begin{array}{l}\text { Petitions } \\
\text { for review } \\
\text { filed } \\
N\end{array}$} & \multicolumn{2}{|c|}{$\begin{array}{l}\text { Petitions for review filed in year y that } \\
\text { were subsequently terminated on the } \\
\text { merits through reversal, vacature, } \\
\text { and/or remand, in whole or in part }\end{array}$} & \multicolumn{2}{|c|}{$\begin{array}{l}\text { Petitions for review filed in year y that were } \\
\text { stibsequently settled and lor dismissed under } \\
\qquad F R A P 42(b)\end{array}$} \\
\hline & & $N$ & $\%$ of total filed & $N$ & $\%$ of total filed \\
\hline 1994 & 70 & 2 & $2.86 \%$ & 5 & $7.14 \%$ \\
\hline 1995 & 81 & 0 & $0.00 \%$ & 4 & $4.94 \%$ \\
\hline 1996 & 48 & 0 & $0.00 \%$ & 3 & $6.25 \%$ \\
\hline 1997 & 254 & 171 & $67.32 \%$ & 8 & $3.15 \%$ \\
\hline 1998 & 44 & 0 & $0.00 \%$ & 4 & $9.09 \%$ \\
\hline 1999 & 57 & 1 & $1.75 \%$ & 5 & $8.77 \%$ \\
\hline 2000 & 53 & 2 & $3.77 \%$ & 1 & $1.89 \%$ \\
\hline 2001 & 67 & 0 & $0.00 \%$ & 5 & $7.46 \%$ \\
\hline 2002 & 298 & 3 & $1.01 \%$ & 26 & $8.72 \%$ \\
\hline 2003 & 356 & 6 & $1.69 \%$ & 23 & $6.46 \%$ \\
\hline 2004 & 371 & 1 & $1,27 \%$ & 9 & 2,430 \\
\hline Total & 1,699 & 186 & 10.950 & 93 & 5.478 \\
\hline
\end{tabular}

Source: Administrative Office data. See supra Part III.A.

Note: The shaded cells indicate that less than $80 \%$ of the petitions for review filed during that year had been terminated as of September 30,2004, and that the observed proportions are therefore not accurate measures of the actual rates. In addition, the figure for cases filed in 2004 includes only those cases that had been filed by September 30, 2004.

Of course it may be that litigants pay less attention to rates of reversal than to the overall number of reversals and the content of the courts' opinions. A large number of reversals might make an impression on people, regardless of how many affirmances are issued in the same year, at least if those reversals establish favorable precedent. In this regard, it may have been significant that the Ninth Circuit reversed 83 BIA decisions in 2000, 105 in 2001, and 156 in 2002. We have not, however, analyzed the content of the opinions in these cases, and so we do not yet know whether they are likely to have encouraged people to file more petitions for review. Moreover, we do not see comparable increases in the number of reversals in the Second or Eleventh Circuits, and we find it unlikely that increases in the number of reversals in the Ninth Circuit, which was already viewed as the Circuit most sympathetic to aliens' claims, ${ }^{308}$ played a large role in the nation-wide surge in petitions for review. $^{309}$

\section{Delay}

Another important circuit court characteristic is case-processing time, or, to put it more bluntly, the amount of delay that a litigant can achieve by filing

308. See supra note 303.

309. As one D.C. lawyer commented to us, there may be some wishful thinking that the Ninth Circuit's views will spread, but "no one here in the [Fourth] [C]ircuit has any such illusions." 
Table 10: Second, Ninth, and Eleventh Circuit Reversal Rates for PETITIONS FOR REVIEW BY JUDGMENT YEAR

\begin{tabular}{|c|c|c|c|c|c|c|c|c|c|}
\hline \multirow{3}{*}{$\begin{array}{c}\text { Judgment } \\
\text { Year }\end{array}$} & \multicolumn{3}{|c|}{$2 d \mathrm{Cir}$} & \multicolumn{3}{|c|}{ 9th Cir. } & \multicolumn{3}{|c|}{ Ilth Cir. } \\
\hline & \multicolumn{2}{|c|}{$\begin{array}{l}\text { Petitions for } \\
\text { review terminated } \\
\text { on the merits } \\
\text { through reversal. } \\
\text { vacature, and/or } \\
\text { remand, in } \\
\text { whole or in part }\end{array}$} & \multirow{2}{*}{\begin{tabular}{|c}
$\begin{array}{c}\text { Total } \\
\text { petitions } \\
\text { for review } \\
\text { terminated }\end{array}$ \\
$N$
\end{tabular}} & \multicolumn{2}{|c|}{$\begin{array}{l}\text { Petitions for } \\
\text { review terminated } \\
\text { on the merits } \\
\text { through reversal, } \\
\text { vacalure, and/or } \\
\text { remand, in } \\
\text { whole or in part }\end{array}$} & \multirow{2}{*}{$\begin{array}{c}\begin{array}{c}\text { Total } \\
\text { petitions } \\
\text { for review } \\
\text { terminated }\end{array} \\
\qquad N\end{array}$} & \multicolumn{2}{|c|}{$\begin{array}{l}\text { Petitions for } \\
\text { review terminated } \\
\text { on the merits } \\
\text { through reversal, } \\
\text { vacature, and/or } \\
\text { remand, in } \\
\text { whole or in part }\end{array}$} & \multirow{2}{*}{$\begin{array}{c}\begin{array}{c}\text { Total } \\
\text { petitions } \\
\text { for review } \\
\text { terminated }\end{array} \\
\\
N\end{array}$} \\
\hline & $N$ & $\begin{array}{l}\text { \% of total } \\
\text { terminated }\end{array}$ & & $N$ & $\begin{array}{l}\text { \% of total } \\
\text { terminated }\end{array}$ & & $N$ & $\begin{array}{l}\text { \% of total } \\
\text { terminated }\end{array}$ & \\
\hline 1994 & 4 & $3.67 \%$ & 109 & 51 & $13.14 \%$ & 388 & 2 & $2.44 \%$ & 82 \\
\hline 1995 & 1 & $0.91 \%$ & 110 & 78 & $14.61 \%$ & 534 & 3 & $3.85 \%$ & 78 \\
\hline 1996 & 2 & $1.85 \%$ & 108 & 59 & $10.30 \%$ & 573 & 0 & $0.00 \%$ & 76 \\
\hline 1997 & 0 & $0.00 \%$ & 147 & 52 & $5.54 \%$ & 939 & 167 & $69.87 \%$ & 239 \\
\hline 1998 & 0 & $0.00 \%$ & 208 & 66 & $9.35 \%$ & 706 & 3 & $5.08 \%$ & 59 \\
\hline 1999 & 1 & $0.38 \%$ & 263 & 65 & $8.92 \%$ & 729 & 1 & $3.57 \%$ & 28 \\
\hline 2000 & 1 & $0.62 \%$ & 162 & 83 & $6.13 \%$ & 1,355 & 0 & $0.00 \%$ & 73 \\
\hline 2001 & 3 & $3.03 \%$ & 99 & 105 & $10.14 \%$ & 1,035 & 1 & $1.49 \%$ & 67 \\
\hline 2002 & 4 & $2.42 \%$ & 165 & 156 & $11.26 \%$ & 1,385 & 0 & $0.00 \%$ & 142 \\
\hline 2003 & 6 & $1.68 \%$ & 358 & 170 & $8.05 \%$ & 2,112 & 6 & $1.82 \%$ & 329 \\
\hline 2004 & 2 & $0.46 \%$ & 434 & 234 & $6.63 \%$ & 3,530 & 6 & $2.19 \%$ & 274 \\
\hline Total & 24 & $1.11 \%$ & 2,163 & 1,119 & $8.42 \%$ & 13,286 & 189 & $13.06 \%$ & 1,447 \\
\hline
\end{tabular}

Source: Administrative Office data. See supra Part III.A.

a petition for review. The EOIR's theory assumes that people are able to delay being expelled by filing petitions for review. While that theory links the increase in filings to a reduction in the delay achievable at the BIA, another possibility is that there was an increase in the delay achievable in the circuit courts, which made them more attractive. Furthermore, inter-circuit differences in delay might help to explain inter-circuit differences in appeal rate.

As with most of our other variables, however, causation is difficult to establish. While the prospect of delay is a factor that can encourage people to file petitions for review, ${ }^{310}$ an increase in petitions for review is also likely to cause delay. If the causation goes in both directions, of course, this can lead to a vicious cycle.

We used the Administrative Office data to calculate the amount of time between the date on which a petition for review was filed and the date on which it was terminated. We then calculated the average completion times for the cohorts of cases filed each year since 1994 and terminated as of

310. "One who is currently receiving a benefit from the government generally has an interest in prolonging a governmental decision whether to terminate that benefit, even though that incentive might be partly offset by a longing for the certainty that a final decision will bring." See Forum Choices, supra note 90 , at 1330-32. 
September 30, 2004. The problem, of course, is to somehow factor in the cases still pending on September 30, 2004. When we ignore these cases, our completion times artificially decrease as the filing dates approach September $2004 .{ }^{311}$ For the purposes of the rough comparisons we are doing here, we factor in these cases for each cohort in two simple ways: First, we report the number of cases still pending on September 30, 2004. Second, we calculate the average completion time for the cohort if all of the pending cases terminated on October 1, 2004. This "minimum average completion time" is still a gross underestimate of what the actual average completion time will be once all of the cases in the cohort terminate, but at least it gives us a starting point from which to work. ${ }^{312}$

We present these calculations for the Second, Ninth, and Eleventh Circuits in Tables 11 through 13. Clearly, there is variation in the average completion time, both between circuits and between filing years. The Second Circuit had the lowest average completion times until 1998, when its average time rose to over a year. Since then, its average times have generally been closer to a year and a half, and may end up being significantly longer. In contrast, the Ninth Circuit has had average completion times of approximately one year fairly consistently, going back at least to the 1994 cohort. Finally, the Eleventh Circuit has had average completion times of approximately a half of a year, except for 1998 and 1999, when its average completion times rose to about a year.

These data show that it is possible to achieve a considerable amount of delay in both the Second and Ninth Circuits, and that the delay available in the Second Circuit increased in 2000 and 2001. It is possible that this increase encouraged litigants to file more petitions for review in 2002, and that the increased delays in 2002 have encouraged a further increase in filings in subsequent years.

We doubt, however, that the availability of delay on its own caused the 2002 increase in appeal rate. First of all, it has been possible to achieve an average of about one year of delay in the Ninth Circuit since at least 1994. It was also possible to achieve around one year of delay in the Second Circuit in 1998 and in the Eleventh Circuit in 1998 and 1999. None of this delay appears to have sparked a surge in appeal rate prior to $2002 .{ }^{313}$ Admittedly, the Eleventh Circuit uses a higher standard than either the Second or Ninth

311. Cf. Huang, supra note 257 , at 246-47.

312. Note that the minimum average completion times for all years combined in each circuit are lower than the average completion times because of the large number of cases filed close to September 2004, which have minimum average times of only a few months due to the way this statistic is calculated.

313. Although we do not know the circuit appeal rates for 1998 and 1999 , we do know that there were no surges in volume other than the Second Circuit's 1999 spike, which resulted from the reactivation of a large group of cases that had been put on hold. See supra notes 230-233 and accompanying text. 
TABle 11: Completion times for Second Circuit PETtTions for Review by FILING YEAR

\begin{tabular}{|c|c|c|c|c|}
\hline $\begin{array}{c}\text { Filing } \\
\text { Year } \\
\text { (y) }\end{array}$ & $\begin{array}{c}\text { Average age } \\
\text { (in months) of } \\
\text { completed } \\
\text { petitions for } \\
\text { review filed } \\
\text { in year y }\end{array}$ & $\begin{array}{c}\text { Minimum average } \\
\text { completion time } \\
\text { (in months) for } \\
\text { petitions for review } \\
\text { filed in year y }\end{array}$ & $\begin{array}{c}\text { Percent of } \\
\text { Number of } \\
\text { filed in year y } \\
\text { still pending on } \\
\text { Sept. 30, 2004 }\end{array}$ & $\begin{array}{c}\text { Potal petitions } \\
\text { for review filed } \\
\text { in year y that } \\
\text { were still pending } \\
\text { on Sept. 30, 2004 }\end{array}$ \\
\hline 1994 & 3.7 & 3.7 & 0 & $0 \%$ \\
\hline 1995 & 3.0 & 3.0 & 0 & $0 \%$ \\
\hline 1996 & 3.3 & 4.4 & 1 & $1 \%$ \\
\hline 1997 & 5.5 & 6.0 & 1 & $1 \%$ \\
\hline 1998 & 6.6 & 12.4 & 24 & $8 \%$ \\
\hline 1999 & 6.4 & 8.9 & 13 & $4 \%$ \\
\hline 2000 & 14.4 & 17.6 & 16 & $8 \%$ \\
\hline 2001 & 12.8 & 16.2 & 23 & $14 \%$ \\
\hline 2002 & 13.7 & 19.4 & 527 & $53 \%$ \\
\hline 2003 & 10.2 & 14.6 & 1,903 & $87 \%$ \\
\hline 2004 & 3.7 & 4.8 & 2,011 & $98 \%$ \\
\hline Total & 9.1 & 11.3 & 4,519 & $68 \%$ \\
\hline
\end{tabular}

Source: Administrative Office data. See supra Part III.A.

Circuits use for granting motions for stays of removal, ${ }^{314}$ so one might argue that case-processing time in the Eleventh Circuit is much less likely to actually delay expulsion. However, the Eleventh Circuit did not adopt that standard in a published decision until 2002, and the standard does not apply to cases governed by IIRIRA's transitional rules. Those cases were probably still relatively numerous in 1998 and $1999 . .^{315}$

Furthermore, if we were to argue that the Second Circuit's increase in delay in 2000 and 2001 to around 1.5 years is responsible for that court's

314. Compare Weng v. U.S. Att'y Gen., 287 F.3d 1335, 1337-38 (11th Cir. 2002) (requiring petitioner to show by "clear and convincing evidence that the entry or execution of [his removal] order is prohibited as a matter of law") (quoting 8 U.S.C. \$ 1252(f)(2)), with Andrieu v. Ashcroft, 253 F.3d 477, 483 (9th Cir. 2001) (en banc) (requiring petitioner to show "either a probability of success on the merits and the possibility of irreparable injury, or that serious legal questions are raised and the balance of hardships tips sharply in petitioner's favor") (quoting Abassi v. INS, 143 F.3d 513, 514 (9th Cir. 1998)), and Mohammed v. Reno, 309 F.3d 95, 100 (2d Cir. 2002) (evaluating stay motion in habeas petition based on "the likelihood of success on the merits, irreparable injury if a stay is denied, substantial injury to the party opposing a stay if one is issued, and the public interest"); see also De Leon v. INS, 115 F.3d 643, 644 (9th Cir. 1997) (adopting procedures by which filing a stay motion results in temporary stay of removal); 9th Cir. General Order No. 6.4(c)(1), available at http:// www.ca9.uscourts.gov/ (last visited Oct. 18, 2005).

315. See Weng, 287 F.3d at 1337-38. 
TABle 12: COMPLETION TIMES FOR NiNTH CIRCUIT PETITIONS FOR REVIEW BY FILING YEAR

\begin{tabular}{|c|c|c|c|c|}
\hline $\begin{array}{c}\text { Filing } \\
\text { Year } \\
(y)\end{array}$ & $\begin{array}{c}\text { Average age } \\
\text { (in months) of } \\
\text { completed } \\
\text { petitions for } \\
\text { review filed } \\
\text { in year y }\end{array}$ & $\begin{array}{c}\text { Minimum average } \\
\text { completion time } \\
\text { (in months) for } \\
\text { petitions for review } \\
\text { fled in year y }\end{array}$ & $\begin{array}{c}\text { Percent of } \\
\text { petitions for review } \\
\text { fled in year y } \\
\text { still pending on } \\
\text { Sept. 30, 2004 }\end{array}$ & $\begin{array}{c}\text { Por review filed } \\
\text { in year y that } \\
\text { were still pending } \\
\text { on Sept. 30, 2004 }\end{array}$ \\
\hline 1994 & 12.3 & 12.3 & 0 & $0 \%$ \\
\hline 1995 & 11.7 & 11.7 & 0 & $0 \%$ \\
\hline 1996 & 10.3 & 10.4 & 1 & $0 \%$ \\
\hline 1997 & 13.2 & 13.4 & 2 & $0 \%$ \\
\hline 1998 & 13.2 & 13.4 & 3 & $0 \%$ \\
\hline 1999 & 12.6 & 12.7 & 6 & $0 \%$ \\
\hline 2000 & 9.6 & 9.9 & 11 & $1 \%$ \\
\hline 2001 & 8.3 & 8.7 & 322 & $9 \%$ \\
\hline 2002 & 12.6 & 13.7 & 1,787 & $44 \%$ \\
\hline 2003 & 9.4 & 11.7 & 3,601 & $83 \%$ \\
\hline 2004 & 3.1 & 4.4 & 5,736 & $31 \%$ \\
\hline Total & 10.9 & 10.4 & 3 & \\
\hline
\end{tabular}

Source: Administrative Office data. See supra Part III.A.

increase in appeal rate, then we also have to explain why earlier delays of one year or even six months did not result in such an increase. Such an explanation may be possible. For instance the additional amount of delay that became available in 2000 and 2001 may have tipped the scales for many people based on the amount of money they could earn during that period and the costs of filing a petition for review. We think it is more likely, however, that something else was at work, and that while the delay may have been an added incentive to file petitions for review, it was not the cause of the surge. ${ }^{316}$

316. A more fundamental problem with the delay theory is that the odds of an alien actually being expelled, regardless of the existence of a petition for review, seem to be fairly low-at least among the groups filing petitions for review. For instance, while people from China and Albania account for a majority of the petitions for review in the Second Circuit, the numbers of people from each of these countries who are expelled each year are relatively small. The highest number of people from China who were actually expelled nationwide in any single fiscal year between 1993 and 2003 was 681 ; the highest number from Albania was 150. See OfFice of ImMigration STATistics, U.S. DeP'T OF Homeland SeC., 2003 Yearbook OF ImMigration Statistics at 161-68 tbl.43 (Sept. 2004), available at http://uscis.gov/graphics/shared/aboutus/statistics/2003Yearbook.pdf; see also CHIN, supra note 24 , at $149-50$ (noting that "there is ample evidence to suggest that only a small proportion of smuggled Chinese who make it to the United States is actually deported."); Benson, supra note 106, 
Table 13: Completion times for Eleventh Circuit Petitions for REvieW BY FILING YEAR

\begin{tabular}{|c|c|c|c|c|}
\hline $\begin{array}{c}\text { Filing } \\
\text { Year } \\
(y)\end{array}$ & $\begin{array}{c}\text { Average age } \\
\text { (in months) of } \\
\text { completed } \\
\text { petitions for } \\
\text { review filed } \\
\text { in year y }\end{array}$ & $\begin{array}{c}\text { Minimum average } \\
\text { completion time } \\
\text { (in months) for } \\
\text { petitions for review } \\
\text { filed in year y }\end{array}$ & $\begin{array}{c}\text { Number of } \\
\text { petitions for review } \\
\text { filed in year y } \\
\text { still pending on } \\
\text { Sept. 30, 2004 }\end{array}$ & $\begin{array}{c}\text { Percent of } \\
\text { total petitions } \\
\text { for review filed } \\
\text { in year y that } \\
\text { were still pending } \\
\text { on Sept. 30, 2004 }\end{array}$ \\
\hline 1994 & 9.6 & 9.6 & 0 & $0.00 \%$ \\
\hline 1995 & 9.3 & 9.3 & 0 & $0.00 \%$ \\
\hline 1996 & 8.4 & 8.4 & 0 & $0.00 \%$ \\
\hline 1997 & 5.2 & 5.2 & 0 & $0.00 \%$ \\
\hline 1998 & 12.5 & 12.5 & 0 & $0.0 \%$ \\
\hline 1999 & 11.5 & 11.5 & 0 & $0.0 \%$ \\
\hline 2000 & 7.2 & 7.2 & 0 & $0.00 \%$ \\
\hline 2001 & 5.6 & 6.0 & 1 & $1.49 \%$ \\
\hline 2002 & 7.0 & 7.1 & 1 & $0.34 \%$ \\
\hline 2003 & 6.7 & 7.3 & 33 & $9.27 \%$ \\
\hline 2004 & 3.6 & 4.1 & 284 & $76.55 \%$ \\
\hline Total & 7.0 & 6.7 & 319 & $18.78 \%$ \\
\hline
\end{tabular}

Source: Administrative Office data. See supra Part III.A.

\section{Shift in Behavior Among Immigration Lawyers and Their Clients}

Unlike our initial explanations based on changes in the composition of the pool of BIA decisions, explanations that focus on BIA and circuit court characteristics rely on a change in behavior on the part of lawyers and their clients. As discussed above, such a change might have been encouraged by general dissatisfaction with the BIA and the increased volume of final expulsion orders. It might also have been encouraged by the initial rush to challenge summary decisions. All of these factors could have triggered a shift in the dynamics of immigration litigation by leading more immigration

at 1442 n. 159 (discussing a Justice Department study showing that the INS failed to remove $89 \%$ of a sample of non-detained people with outstanding expulsion orders, and concluding that "judicial review of immigration proceedings is not the major, or even a significant, cause of delay in the removal of noncitizens").

However, even if the risk of being expelled is very small, the cost of being expelled may be enormous. It is therefore not inconceivable that aliens may be filing petitions for review purely for purposes of delay. Leaving aside ethical considerations and the possibility of sanctions, for someone who is making $\$ 1359$ per month in the United States as compared to $\$ 100$ per month at home, see, e.g., CHIN, supra note 24, at 14, a stay of removal that will last at least a year may be well worth the costs involved in filing a petition for review. See, e.g., ChIN, supra note 24 , at 14. 
lawyers to focus their practices on petitions for review and by generating increased interest among many communities of noncitizens.

The stage for such a change was probably set with a general increase in the number of trained immigration lawyers over the past two decades. We take it for granted that most law schools today offer courses in immigration law, but that was not the case twenty years ago. ${ }^{317}$ As an academic field, immigration law has only recently begun to flourish, ${ }^{318}$ and there has been a huge growth in the practicing bar since the 1980 s. $^{319}$ If we look at the EOIR's data on representational status at the agency level, we see a mostly steady increase since 1996 in the proportion of BIA appeals involving aliens represented by counsel (Table 14).

TABLE 14. BIA DECISIONS ARISING FROM IJ PROCEEDINGS BY REPRESENTATIONAL STATUS

\begin{tabular}{|c|c|c|c|}
\hline Fiscal Year & Represented & Unrepresented & Total \\
\hline 1996 & $8,360(59 \%)$ & 5,809 & 14,169 \\
\hline 1997 & $10,889(56 \%)$ & 8,556 & 19,445 \\
\hline 1998 & $15,041(58 \%)$ & 10,798 & 25,839 \\
\hline 1999 & $12,337(58 \%)$ & 8,994 & 21,331 \\
\hline 2000 & $11,372(63 \%)$ & 6,755 & 18,127 \\
\hline 2001 & $17,375(64 \%)$ & 9,898 & 27,273 \\
\hline 2002 & $29,558(65 \%)$ & 15,672 & 45,230 \\
\hline 2003 & $33,163(72 \%)$ & 12,942 & 46,105 \\
\hline 2004 & $32,193(70 \%)$ & 13,860 & 46,053 \\
\hline
\end{tabular}

Source: EOIR statistical yearbooks. ${ }^{320}$

317. See Stephen H. Legomsky, Immigration and Refugee Law and Policy, at vii (3d ed. Supp. 2003) (reporting that "the law school [in 1987] that offered a course in immigration was the exception rather than the norm," whereas today immigration law is taught at "the vast majority of United States law schools, many of which also offer immigration clinics and specialized courses in refugee law or citizenship law").

318. "Scholarship in this once unknown field is now abundant, sophisticated, and diverse." Id.

319. See Lenni B. Benson, Making Paper Dolls: In Which the Author Explains How Restrictions on Judicial Review and Immigration Law Relief Increase Immigration Cases in the Federal Courts, N.Y.L. SCH. L. REv. (forthcoming) (on file with authors). We also have anecdotal evidence that students, and even prospective students, are increasingly expressing interest in immigration law classes and clinical programs. See E-mail from Estelle McKee, Co-Director, Cornell Asylum and Convention Against Torture Appellate Clinic, to John R.B. Palmer (Apr. 9, 2005, 09:39:02 EST) (on file with authors).

320. For fiscal years 1998 through 2004, the data are taken directly from EOIR YB 2004, supra note 7, at W1. The data for fiscal year 1997 is calculated from the percentage of represented cases reported in EOIR YB 2001, supra note 299, at K1, and the total appeals from IJs completed by the BIA, reported in EOIR YB 2001, supra note 299, at E2 tbl.6. The data for fiscal year 1996 is calculated from the percentage of represented cases reported in EOIR YB 2000, supra note 299, at $\mathrm{K} 1$, and the total appeals from IJs completed by the BIA, reported in EOIR YB 2000, supra note 299, 
In addition to the expansion of the immigration bar, the 1996 amendments to the INA may have created incentives to litigate an increasing number of issues in expulsion proceedings, and to litigate these issues as hard as possible. In a recent article, Professor Lenni Benson describes how Congress's restriction of available relief, its expansion of bars to reentry following periods of unlawful presence, and its attempt to limit judicial review may have all had the unintended consequence of encouraging more litigation. ${ }^{321}$ She notes, for instance, that many attorneys would previously advise their clients to concede grounds of deportability and focus only on obtaining discretionary relief. ${ }^{322}$ Today, however, the tendency is to fight tooth and nail on every legal issue. This occurs because the consequences of being found removable are so high, there is less relief available, and much of the discretionary relief is not subject to judicial review. ${ }^{323}$

With an expandet and increasingly litigious immigration bar, the actual triggering event for the 2002 shift in immigration litigation to the federal courts could have been a combination of the BIA's increased output of final orders of removal, general dissatisfaction with the BIA, and a rush to challenge the BIA's procedural changes on their face. For lawyers who practice in both the BIA and the courts of appeals, the sudden flood of BIA decisions in March 2002 meant a huge increase in work. Lawyers who had become accustomed to the BIA's case processing time before 2002 suddenly faced hundreds of BIA decisions and thirty-day deadlines for filing petitions for review. Moreover, until the facial challenges were rejected by the courts of appeals, many of these new decisions were arguably vulnerable to attack regardless of the merits of the underlying cases. Indeed, many lawyers felt a deep sense of injustice at the BIA's procedures and were probably eager to challenge them as a matter of principle.

As a result, lawyers must have started to reflexively file petitions for review, to expand their practices in the courts of appeals, and to begin passing cases on to anyone else with time to take them. Lawyers who had previously practiced only at the administrative level moved into the courts of appeals for the first time to fill the demand. Lawyers who had never filed more than a handful of petitions for review per year now began filing hundreds.

This was a break from the past. For a number of reasons, there had

\footnotetext{
at E2 tbl.6. In each of these latter two cases, the statistical yearbooks do not explicitly state that the percentage of represented cases is based on appeals from IJ decisions only, as opposed to total completions. However, this appears to be what is meant, since the percentages reported for fiscal years 2000 and 2001 match the percentages reported in the 2004 yearbook, which does explicitly state that they are limited to appeals from IJs. It should also be noted that there is some variation between the yearbooks in the numbers reported for certain fiscal years. We assume this difference is due to corrections, and that the most recently reported figures are the most accurate.

321. Benson, supra note 319. This may also result from a reduction in the opportunities and incentives for settlement at the administrative level. See E-mail from Charles Roth, Midwest Immigrant \& Human Rights Center, to Stephen W. Yale-Loehr (Sept. 4, 2005) (on file with authors).

322. Benson, supra note 319 .

323. Id.
} 
historically been a hesitation among immigration lawyers to litigate in the courts of appeals. When asylum claims began to burgeon at the agency level at the end of the 1980s, immigration lawyers could have brought them into federal court as well, but they held back to a large degree. At the time, this was attributed to a fear of adverse precedent. ${ }^{324}$ Many immigration lawyers may have felt that their best chances lay in persuading the BIA of the validity of their claims and that judicial review should be saved for exceptional circumstances only. This attitude seems to have changed in 2002. Many lawyers have lost faith in the BIA and are now concentrating their energy and resources on the federal courts instead.

Economics may have also kept federal court litigation low in the past. There simply may not have been enough work to make petitions for review economically viable. Many immigration practices overcome the problem of low-paying clients by utilizing economies of scale. Harldling the same type of case in the same procedural posture many times may be the only way to make ends meet. Until there were enough people willing to pay for petitions for review within a given geographic area, it may have been difficult for lawyers following this business model to spend time in an unfamiliar forum. This is not to say that the move into the federal courts was purely mercenary; it is simply that the removal of an economic obstacle may have been a necessary condition before the move could take place.

Of course the shift in the immigration bar must have been accompanied by a shift within the population of potential clients. Increased interest in petitions for review among people faced with expulsion orders could have been driven partly by the shift in the immigration bar, and it could have also been partly responsible for driving that shift. It could be that the BIA's increased volume created a "critical mass" of people within certain communities who were all facing adverse BIA decisions at the same time. By word of mouth and local news stories, the petition for review may have suddenly appeared on the radar screen for many people who were previously unaware that they had the option to litigate beyond the administrative level. When these people then heard of friends or neighbors obtaining relief through such litigation, the draw may have been irresistible.

Whatever the initial reasons for the shift in immigration litigation, once the move into federal court began, it may have had a self-perpetuating effect. Even now that the facial challenges to the procedural changes have been rejected, the increased capacity to litigate in the courts of appeals may have a vacuum-like tendency to keep itself full. As lawyers have become less afraid of adverse precedent and more comfortable with petitions for review, they have geared their practices toward filing a large number of petitions. Additionally, clients may be demanding to go forward with petitions regard-

324. See David A. Martin, Reforming Asylum Adjudication: On Navigating the Coast of Bohemia, 138 U. PA. L. REv. 1247, 1325 (1990). 
less of whether or not they have a realistic chance of success.

Is there evidence to support this theory? Within the Second Circuit, at least, it is clear that most petitions for review are filed by lawyers, and that most are filed by a relatively small group of lawyers. As Table 15 shows, $87 \%$ of the petitions for review pending on the Second Circuit's docket on April 21,2005 , were represented by counsel. Further, $46 \%$ were represented by just twenty law offices, with many of these offices handling over 100 petitions each. These are not large firms; they are mostly either solo practitioners or offices employing two or three attorneys. Second Circuit records indicate that none of these offices had filed more than thirty petitions for review in any one year from 1989 through 2001. Most had filed less than ten and many had filed none at all. ${ }^{325}$ It is not that these lawyers were inexperienced: many of them had been litigating quite successfully before the immigration courts and the BIA, and their advocacy has led to important precedential decisions in both the BIA and the Second Circuit. Clearly, however, there has been a major change in the focus of their practices since 2002.

The role played by lawyers in driving the appeal rate is also elucidated by the Administrative Office data, which contain information, starting in October 1997 , as to whether or not each petition for review was filed pro se. ${ }^{326}$ As Figure 9 shows, there has been an increase in the monthly volume of both counseled and pro se petitions for review since April 2002.

To get a sense of whether the increase in appeal rate is being driven more by counseled petitions than by pro se petitions, we broke down our estimated appeal rates into counseled and pro se appeals. We estimated the counseled appeal rate by dividing the number of counseled petitions for review filed in month $m+l$ by the number of BIA decisions issued in month $m$. We likewise estimated the pro se appeal rate by dividing the number of pro se petitions for review filed in month $m+1$ by the number of BIA decisions issued in month $m$.

We found that the counseled appeal rate is not only higher than the pro se appeal rate, but that it also increases more steeply after April 2002 than does the pro se appeal rate (Figure 10). In other words, the overall increase in appeal rate has been driven more by counseled cases than by pro se cases.

325. Although we tried to investigate the nationwide shift in law practices in a systematic way by sending out surveys, we received too few responses to draw any general conclusions. See supra Part III.F.

326. The data indicate whether "appellant," "appellee," or both were pro se at the time of filing. In the case of petitions for review, one would expect to find either the "appellant"-i.e., petitionerpro se, or neither party pro se (since the respondent is the government), and this was mostly true. In the small number of cases that indicated a pro se "appellee," we assumed that this was a data-entry error due to confusion over who the "appellant" and "appellee" are in a petition for review; we therefore counted these cases as having pro se "appellants."

The data also indicate whether one or both parties were pro se at the time of termination. We did not analyze this information. 
TABle 15: LAW OfFICES WITH MOST PETITIONS FOR REVIEW PENDING IN SECOND CIRCUIT

\begin{tabular}{|l|c|c|}
\hline \multicolumn{1}{|c|}{ Law Office } & $\begin{array}{c}\text { Petitions for review } \\
\text { pending on } \\
\text { April 21, 2005 }\end{array}$ & $\begin{array}{c}\text { Percent of total pending } \\
\text { petitions for review on } \\
\text { April 21, 2005 }\end{array}$ \\
\hline $\mathrm{A}$ & 308 & $6.26 \%$ \\
\hline $\mathrm{B}$ & 281 & $5.71 \%$ \\
\hline $\mathrm{C}$ & 193 & $3.92 \%$ \\
\hline $\mathrm{D}$ & 182 & $3.70 \%$ \\
\hline $\mathrm{E}$ & 168 & $3.42 \%$ \\
\hline $\mathrm{F}$ & 162 & $3.29 \%$ \\
\hline $\mathrm{G}$ & 135 & $2.75 \%$ \\
\hline $\mathrm{H}$ & 96 & $1.95 \%$ \\
\hline $\mathrm{I}$ & 95 & $1.93 \%$ \\
\hline $\mathrm{J}$ & 95 & $1.93 \%$ \\
\hline $\mathrm{K}$ & 90 & $1.83 \%$ \\
\hline $\mathrm{L}$ & 73 & $1.48 \%$ \\
\hline $\mathrm{M}$ & 63 & $1.28 \%$ \\
\hline $\mathrm{N}$ & 58 & $1.18 \%$ \\
\hline $\mathrm{O}$ & 53 & $1.08 \%$ \\
\hline $\mathrm{P}$ & 53 & $1.08 \%$ \\
\hline $\mathrm{Q}$ & 51 & $1.04 \%$ \\
\hline $\mathrm{R}$ & 46 & $0.94 \%$ \\
\hline $\mathrm{S}$ & 45 & $0.92 \%$ \\
\hline $\mathrm{T}$ & 42 & $0.85 \%$ \\
\hline Total for top 10 offices & 1,715 & $34.87 \%$ \\
\hline Total for top 20 offices & 2,289 & $46.54 \%$ \\
\hline Total represented cases & 4,290 & $87.23 \%$ \\
\hline Total pro se cases & 606 & $12.32 \%$ \\
\hline Grand total & 4,918 & \\
\hline Sore: Scond & 95 & \\
\hline
\end{tabular}

Souce: Second Circuit internal docket database. See supra Part III.B.

Note: We have substituted letters in place of the names of the law offices because our purpose is to show the degree to which petitions for review are concentrated among a small number of lawyers, not to draw attention to the identity of those lawyers. Grand total includes twenty-two cases with missing data.

Although the counseled appeal rate dropped during the summer of 2003, it started rising again the following fall, and we assume that it continued to rise, 
FIGURE 9. MONTHLY VOLUME OF PETITIONS FOR REVIEW NATIONWIDE BY REPRESENTATIONAL STATUS

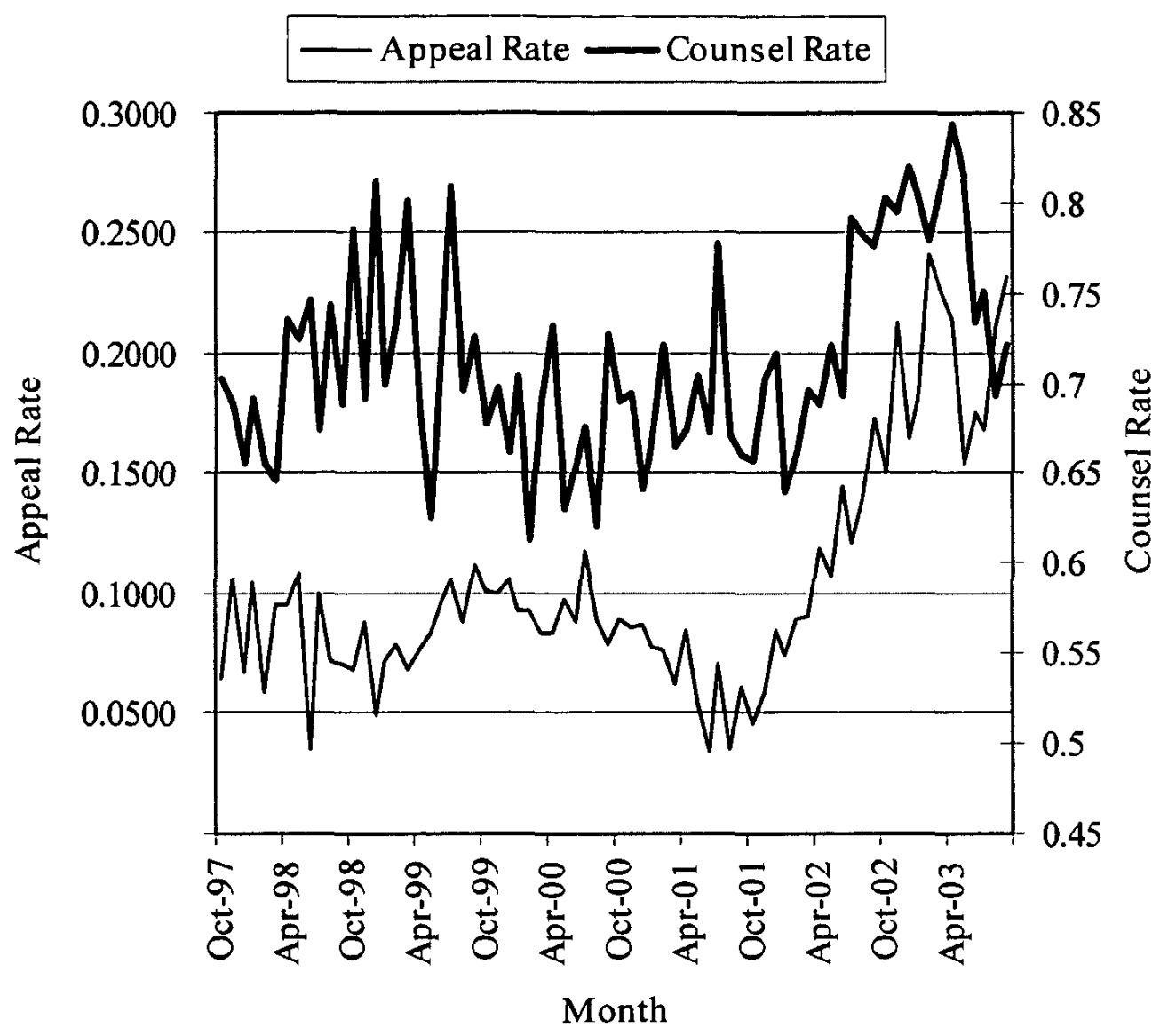

Source: Administrative Office data. See supra Part III.A.

along with the rise in overall appeal rate, throughout $2004 .{ }^{327}$

We also calculated the proportion of each month's petitions for review that were filed by counsel-what we will term the "counsel rate"-and we compared this with the monthly appeal rates. In the time series plot in Figure 11 , we see that the monthly proportion of counseled petitions for review has ranged between about 0.60 and 0.85 since October 1997. Prior to April 2002, the proportion oscillated relatively frequently between highs and lows and mostly remained below 0.80 . This may be indicative of the fact that immigration lawyers' forays into the federal courts were sporadic at that time. In contrast, after April 2002 we see a more sustained rise in counsel rate, which stayed near 0.80 and roughly paralleled the rise in appeal rate during that period. If our theory is correct, this reflects the shift in the

327. See supra Figure 5, which shows the rise in the overall appeal rate during fiscal year 2004. However, we do not yet have information on the number of counseled cases after September 2003. 
Figure 10. Estimated APPEAL RATES FOR BIA DECISIONS NATIONWIDE BY REPRESENTATIONAL STATUS

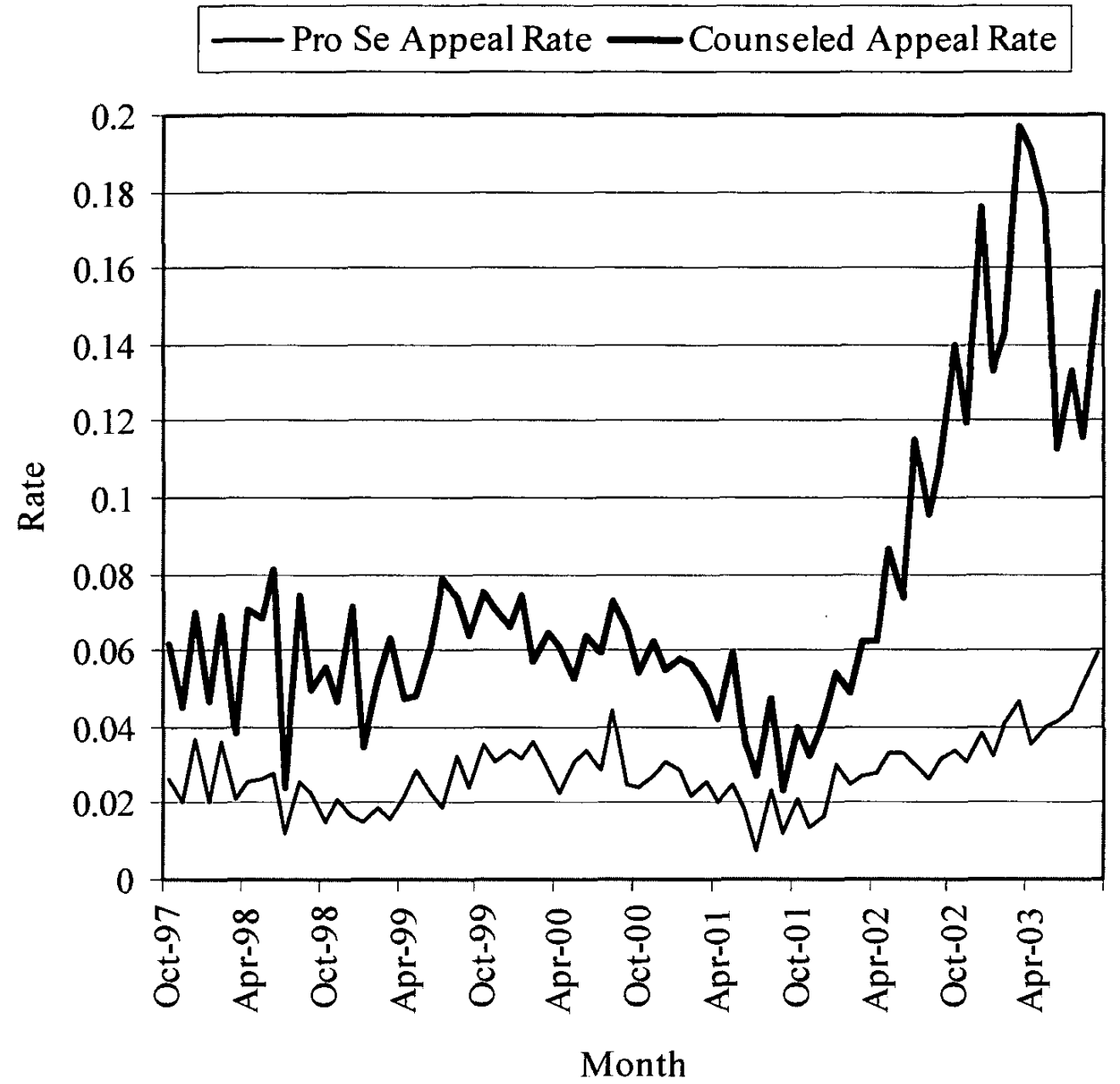

Source: Administrative Office data, see supra Part III.A., and EOIR response to authors' FOIA request, see supra Part III.D.

immigration bar such that the federal courts now became the focus of many lawyers' practices. Counsel rate dropped back to 0.70 in August 2003, also paralleling the drop in appeal rate, but it started rising again in September, and we expect that it continued to rise with appeal rate in the months since then. $^{328}$

All of this supports the theory that there has been a shift in the immigration bar, and that this shift contributed to the increase in appeal rate. We also have anecdotal evidence that communities of noncitizens are increasingly aware of the option of filing petitions for review. For instance, we are told that

328. See supra note 327. 
Figure 11. Estimated apPeal RATE AND "COUNSEl RATE" NATIONWIDE

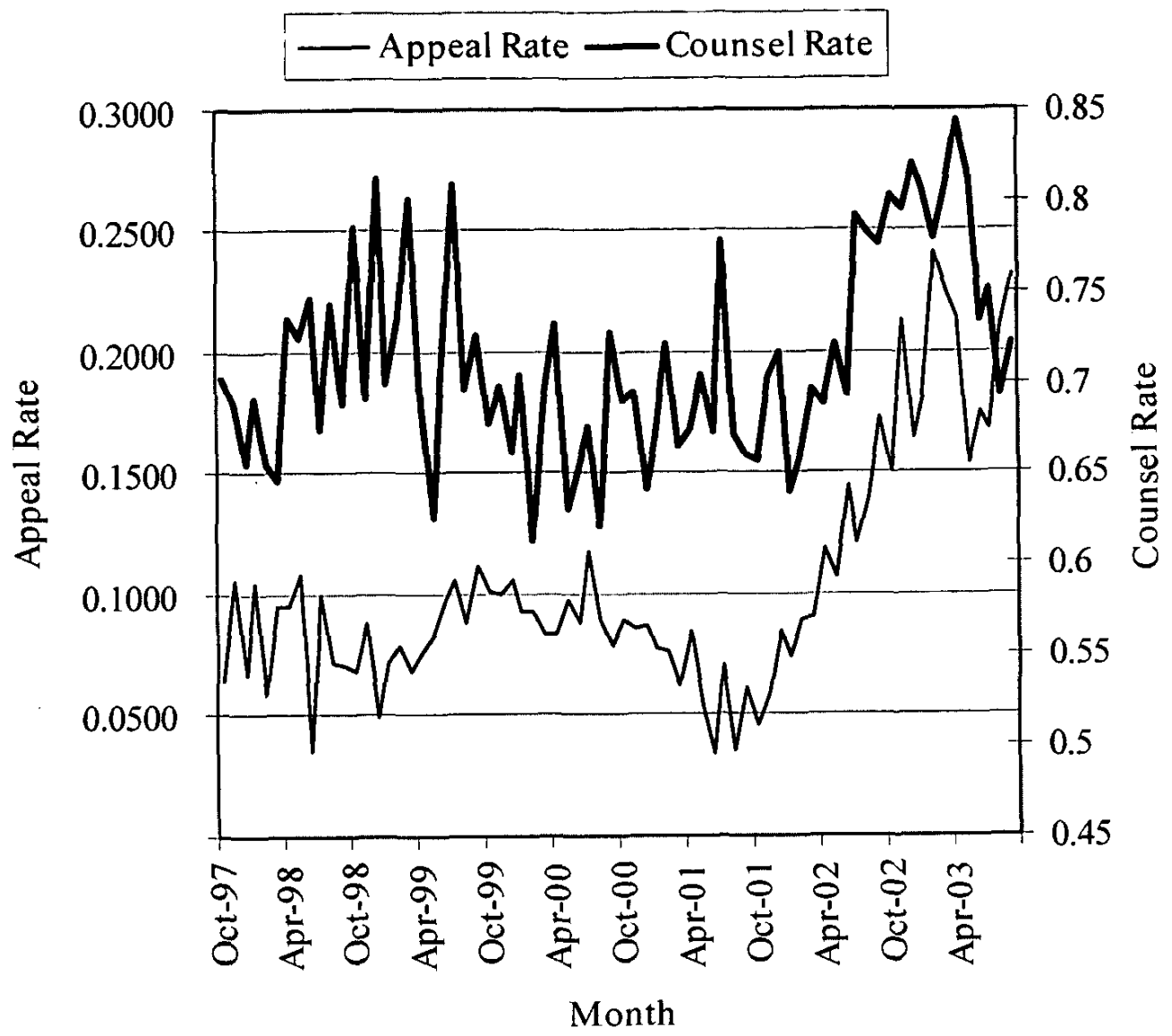

Source: Administrative Office data, see supra Part III.A., and EOIR response to authors' FOIA request, see supra Part III.D.

Chinese-language newspapers in New York frequently publish stories on Second Circuit decisions in petitions for review filed by Chinese asylumseekers. $^{329}$

\section{Conclusions}

We have taken a close look at the patterns and dynamics of immigration litigation in the federal courts, and we have explored a number of variables that may have contributed to the surge in petitions for review that began in 2002. There has clearly been an increase in the volume of BIA decisions, but this accounts for only part of the surge. The other part is accounted for by an

329. See, e.g., David Hsieh, Interpretation of China's One Child Policy Varies-Political Asylum a Game of Lottery, WoRLd JouRnal, Feb. 15, 2005 (reporting on Hao Jiang v. INS, No. 03-4519, 118 Fed. Appx. 565, 2004 WL 2980414 (2d Cir. 2004)), translated from Chinese and reprinted in Voices That Must Be Heard: The Best of New York's Ethnic and Immigrant Press, available at http:/I www.indypressny.org/article.php3?ArticleID = 1928 (last visited May 15, 2005). 
increase in the rate of appeal, and we have focused on why that might have occurred. We have explored the possibility that the increase is caused by increases in the proportion of final expulsion orders, reversible error, summary procedures, prompt decisions, appealable substantive issues, aliens with high expulsion costs, and non-detained aliens in the pool of BIA decisions. We have also explored the possibility that the increase was caused by certain characteristics of the BIA and the courts of appeals or by a shift in behavior among immigration lawyers and their clients.

We are unable to rule out any of these variables as potential causes of the increased appeal rate, but our data support only a few of them. Specifically, our data support the hypothesis that appeal rate has increased as a result of a surge in BIA decisions that leave non-detained aliens with final expulsion orders and a fundamental shift in behavior among lawyers and their clients, causing them to focus their litigation in the courts of appeals for the first time. We think this fundamental shift was triggered by the high volume of final expulsion orders that began to be issued starting in March 2002 and a general dissatisfaction with the BIA's review.

This hypothesis is only a starting point, as we lack much of the data that would be needed to thoroughly test it. We present our findings now, however, in the hope that they will form a basis for further research and discussion about the causes of the immigration surge, as well as the dynamics of immigration litigation generally. 
APPENDIX

TABLE 16: COMPOSITION OF SAMPLED BIA DECISIONS ON DIRECT APPEAL FROM SECOND CiRCUIT IJS

\begin{tabular}{|c|c|c|c|c|c|}
\hline \multirow{2}{*}{$\begin{array}{c}\text { Asylum, } \\
\text { withholding, } \\
\text { and/or CAT? }\end{array}$} & \multirow{2}{*}{ Country of origin } & \multicolumn{3}{|c|}{ Final order of removal? } & \multirow{2}{*}{$\begin{array}{c}\text { Grand } \\
\text { Total }\end{array}$} \\
\hline & & No & Yes & Unknown & \\
\hline \multirow{12}{*}{ No } & Colombia & 0 & 1 & 0 & 1 \\
\hline & Dom. Rep. & 0 & 5 & 0 & 5 \\
\hline & Ecuador & 1 & 0 & 0 & 1 \\
\hline & El Salvador & 0 & 1 & 0 & 1 \\
\hline & Ghana & $\overline{0}$ & 1 & 0 & 1 \\
\hline & Guinea & 0 & 1 & 0 & 1 \\
\hline & Guyana & 0 & 1 & 0 & 1 \\
\hline & Haiti & 0 & 1 & 0 & 1 \\
\hline & Jamaica & 0 & 2 & 0 & 2 \\
\hline & Pakistan & 0 & 1 & 0 & 1 \\
\hline & Trin. \& Tobago & 1 & $\overrightarrow{0}$ & 0 & 1 \\
\hline & Total & 2 & 14 & 0 & 16 \\
\hline \multirow{19}{*}{ Yes } & Albania & 0 & 3 & 0 & 3 \\
\hline & Bangladesh & 1 & 1 & 0 & 2 \\
\hline & China & 8 & 45 & 0 & 53 \\
\hline & Dom. Rep. & 0 & 1 & 0 & 1 \\
\hline & Egypt & 0 & 1 & 0 & 1 \\
\hline & Eritrea & 0 & 1 & 0 & 1 \\
\hline & Estonia & 0 & 1 & 0 & 1 \\
\hline & Guatemala & 0 & 1 & 0 & 1 \\
\hline & Guinea & 0 & 1 & 0 & 1 \\
\hline & Haiti & 0 & 2 & 0 & 2 \\
\hline & India & 0 & 2 & 0 & 2 \\
\hline & Mauritania & 1 & 0 & 0 & 1 \\
\hline & Pakistan & 0 & 1 & 0 & 1 \\
\hline & Serb. \& Mont. & 0 & 5 & 0 & 5 \\
\hline & Sierra Leone & 0 & 1 & 0 & 1 \\
\hline & Sri Lanka & 2 & 0 & 0 & 2 \\
\hline & Yemen & 0 & 1 & 0 & 1 \\
\hline & Unknown & 0 & 2 & 0 & 2 \\
\hline & Total & 12 & 69 & 0 & 81 \\
\hline Unknown & Unknown & 1 & 1 & 1 & 3 \\
\hline & Grand Total & 15 & 84 & 1 & 100 \\
\hline
\end{tabular}

Source: Random sample of BIA decisions issued between May 1 and August 31, 2004, in direct appeals from IJs located within the Second Circuit. See supra Part III.E.3. 
TABLE 17: COMPOSITION OF SAMPLED BIA DECISIONS ON DIRECT APPEAL FROM NinTH CiRCUIT IJS

\begin{tabular}{|c|c|c|c|c|c|}
\hline \multirow{2}{*}{$\begin{array}{c}\text { Asylum, } \\
\text { withholding, } \\
\text { and/or CAT? }\end{array}$} & \multirow{2}{*}{ Country of origin } & \multicolumn{3}{|c|}{ Final order of removal? } & \multirow{2}{*}{$\begin{array}{c}\text { Grand } \\
\text { Total }\end{array}$} \\
\hline & & No & Yes & Unknown & \\
\hline \multirow{6}{*}{ No } & Guatemala & 0 & 2 & 0 & 2 \\
\hline & Honduras & 1 & 1 & 0 & 2 \\
\hline & Mexico & 5 & 37 & 0 & 42 \\
\hline & Philippines & 0 & 1 & 0 & 1 \\
\hline & South Korea & 0 & 1 & 0 & 1 \\
\hline & Total & 6 & $\overline{42}$ & 0 & 48 \\
\hline \multirow{17}{*}{ Yes } & Unknown & 1 & 0 & 0 & 1 \\
\hline & Armenia & 0 & 1 & 0 & 1 \\
\hline & China & $\overline{4}$ & 5 & 0 & 9 \\
\hline & Egypt & 0 & 1 & 0 & 1 \\
\hline & El Salvador & 0 & 2 & 0 & 2 \\
\hline & Guatemala & 0 & 3 & 0 & 3 \\
\hline & Honduras & 0 & 1 & 0 & 1 \\
\hline & India & 1 & 0 & 0 & 1 \\
\hline & Indonesia & 1 & 1 & 0 & 2 \\
\hline & Iraq & 1 & 2 & 0 & 3 \\
\hline & Jordan & 0 & 1 & 0 & 1 \\
\hline & Lebanon & 0 & 1 & 0 & 1 \\
\hline & Mexico & 0 & 4 & 0 & 4 \\
\hline & Nigeria & 0 & 1 & 0 & 1 \\
\hline & Pakistan & 0 & 1 & 0 & 1 \\
\hline & Russia & 0 & 3 & 0 & 3 \\
\hline & Total & 8 & 27 & 0 & 35 \\
\hline Unknown & Unknown & 4 & 3 & 10 & 17 \\
\hline \multicolumn{2}{|c|}{ Grand Total } & 18 & 72 & 10 & 100 \\
\hline
\end{tabular}

Source: Random sample of BIA decisions issued between May 1 and August 31, 2004, in direct appeals from IJs located within the Ninth Circuit. See supra Part III.E.3. 
TABLE 18: COMPOSITION OF SAMPLED BIA DECISIONS ON DIRECT APPEAL FROM Eleventh CiRcuit IJs

\begin{tabular}{|c|c|c|c|c|c|}
\hline \multirow{2}{*}{$\begin{array}{c}\text { Asylum, } \\
\text { withholding, } \\
\text { and/or CAT? }\end{array}$} & \multirow{2}{*}{ Country of origin } & \multicolumn{3}{|c|}{ Final order of removal? } & \multirow{2}{*}{$\begin{array}{l}\text { Grand } \\
\text { Total }\end{array}$} \\
\hline & & No & Yes & Unknown & \\
\hline \multirow{7}{*}{ No } & Bahamas & 0 & 1 & 0 & 1 \\
\hline & Haiti & 0 & 3 & 0 & 3 \\
\hline & India & 0 & 1 & 0 & 1 \\
\hline & Jamaica & 0 & 1 & 0 & 1 \\
\hline & Mexico & 0 & 3 & 0 & 3 \\
\hline & Peru & 1 & 0 & 0 & 1 \\
\hline & Total & 1 & 9 & 0 & 10 \\
\hline \multirow{11}{*}{ Yes } & China & 0 & 2 & 0 & 2 \\
\hline & Colombia & 0 & 37 & 0 & 37 \\
\hline & Cuba & 0 & 1 & 0 & 1 \\
\hline & Guatemala & 0 & 1 & 0 & 1 \\
\hline & Guyana & 0 & 2 & 0 & 2 \\
\hline & Haiti & 0 & 37 & 0 & 37 \\
\hline & Myanmar & 0 & 1 & 0 & 1 \\
\hline & Nicaragua & 0 & 2 & 0 & 2 \\
\hline & Peru & 0 & 1 & 0 & 1 \\
\hline & Sudan & 0 & 1 & 0 & 1 \\
\hline & Total & 0 & 85 & 0 & 85 \\
\hline \multirow{3}{*}{ Unknown } & Unknown & 2 & 0 & 2 & 4 \\
\hline & Haiti & 0 & 0 & 1 & 1 \\
\hline & Total & 2 & 0 & 3 & 5 \\
\hline \multicolumn{2}{|c|}{ Grand Total } & 3 & 94 & 3 & 100 \\
\hline
\end{tabular}

Source: Random sample of BIA decisions issued between May 1 and August 31, 2004, in direct appeals from IJs located within the Ninth Circuit. See supra Part III.E.3. 
TABle 19: Countries of ORIGIN IN SAMPLED SECOND CiRCUIT PETITIONS FOR REVIEW

\begin{tabular}{|c|c|c|}
\hline Country of Origin & $\begin{array}{l}\text { Number of cases } \\
\text { in sample (n) }\end{array}$ & $\begin{array}{l}\text { Percent of } \\
\text { total }\end{array}$ \\
\hline Albania & 17 & $8.99 \%$ \\
\hline Bangladesh & 4 & $2.12 \%$ \\
\hline Burkina Faso & 1 & $0.53 \%$ \\
\hline Chad & 1 & $0.53 \%$ \\
\hline China & 107 & $56.61 \%$ \\
\hline Colombia & 2 & $1.06 \%$ \\
\hline Croatia & 1 & $0.53 \%$ \\
\hline Egypt & 6 & $3.17 \%$ \\
\hline El Salvador & 1 & $0.53 \%$ \\
\hline Estonia & 1 & $0.53 \%$ \\
\hline Ethiopia & 1 & $0.53 \%$ \\
\hline France & 1 & $0.53 \%$ \\
\hline Gambia & 1 & $0.53 \%$ \\
\hline Guinea & 1 & $0.53 \%$ \\
\hline Honduras & 1 & $0.53 \%$ \\
\hline India & 8 & $4.23 \%$ \\
\hline Israel & 1 & $0.53 \%$ \\
\hline Jamaica & 2 & $1.06 \%$ \\
\hline Korea & 1 & $0.53 \%$ \\
\hline Lebanon & 1 & $0.53 \%$ \\
\hline Macedonia & 3 & $1.59 \%$ \\
\hline Mauritania & 4 & $2.12 \%$ \\
\hline Nepal & 1 & $0.53 \%$ \\
\hline Nigeria & 1 & $0.53 \%$ \\
\hline Pakistan & 2 & $1.06 \%$ \\
\hline Philippines & 1 & $0.53 \%$ \\
\hline Poland & 1 & $0.53 \%$ \\
\hline Romania & 1 & $0.53 \%$ \\
\hline Russia & 1 & $0.53 \%$ \\
\hline Serb. \& Mont. & 5 & $2.65 \%$ \\
\hline Sierra Leone & 1 & $0.53 \%$ \\
\hline Sri Lanka & 3 & $1.59 \%$ \\
\hline Turkey & 1 & $0.53 \%$ \\
\hline Ukraine & 3 & $1.59 \%$ \\
\hline Uzbekistan & 2 & $1.06 \%$ \\
\hline Total & 189 & \\
\hline
\end{tabular}

Source: Random sample of petitions for review pending in the Second Circuit on April 12, 2005, for which records had been filed before January 2005. See supra Part III.C. 
TABLE 20: BIA'S USE OF SUMMARY PROCEDURES SINCE JANUARY 1999

\begin{tabular}{|c|c|c|c|c|c|c|c|}
\hline \multirow{2}{*}{ Monsh } & \multicolumn{2}{|c|}{ Single board member decisions } & \multicolumn{2}{|c|}{ Affirmances without opinion } & \multicolumn{2}{|c|}{ Summary dismissals } & \multirow{2}{*}{$\begin{array}{c}\begin{array}{c}\text { Total BIA } \\
\text { decisions }\end{array} \\
N\end{array}$} \\
\hline & $N$ & Percent of total & $N$ & Percent of total & $N$ & Percent of total & \\
\hline Jan-99 & 1 & $0 \%$ & 0 & $0 \%$ & 46 & $3 \%$ & 1,678 \\
\hline Feb-99 & 6 & $\overline{0} \%$ & 0 & $0 \%$ & 28 & $2 \%$ & 1,672 \\
\hline Mar-99 & 7 & $0 \%$ & 0 & $0 \%$ & 48 & $2 \%$ & 2,330 \\
\hline Apr-99 & 13 & $1 \%$ & 0 & $0 \%$ & 22 & $1 \%$ & 1,562 \\
\hline May-99 & 12 & $1 \%$ & 0 & $0 \%$ & 18 & $1 \%$ & 1,516 \\
\hline Jun-99 & 21 & $1 \%$ & 0 & $0 \%$ & 36 & $1 \%$ & 2,569 \\
\hline Jul-99 & 22 & $1 \%$ & 0 & $0 \%$ & 41 & $2 \%$ & 1,783 \\
\hline Aug-99 & 13 & $1 \%$ & 0 & $0 \%$ & 21 & $1 \%$ & 1,825 \\
\hline Sep-99 & 20 & $1 \%$ & 0 & $0 \%$ & 22 & $2 \%$ & 1,375 \\
\hline Oct-99 & 36 & $2 \%$ & 0 & $0 \%$ & 40 & $2 \%$ & 1,821 \\
\hline Nov-99 & 22 & $2 \%$ & 0 & $0 \%$ & 22 & $2 \%$ & 1,421 \\
\hline Dec-99 & 19 & $1 \%$ & 0 & $0 \%$ & 19 & $1 \%$ & 1,343 \\
\hline Jan-00 & 10 & $1 \%$ & 0 & $0 \%$ & 21 & $2 \%$ & 1,086 \\
\hline Feb-00 & 19 & $1 \%$ & 0 & $0 \%$ & 29 & $2 \%$ & 1,802 \\
\hline Mar-00 & 28 & $2 \%$ & 0 & $0 \%$ & 25 & $1 \%$ & 1,704 \\
\hline Apr-00 & 29 & $2 \%$ & 0 & $0 \%$ & 13 & $1 \%$ & 1,196 \\
\hline May-00 & 36 & $2 \%$ & 0 & $0 \%$ & 35 & $2 \%$ & 1,745 \\
\hline Jun-00 & 57 & $3 \%$ & 0 & $0 \%$ & 33 & $2 \%$ & 1,646 \\
\hline Jul-00 & 53 & $4 \%$ & 0 & $0 \%$ & 14 & $1 \%$ & 1,262 \\
\hline Aug-00 & 83 & $6 \%$ & 0 & $0 \%$ & 25 & $2 \%$ & $1, \overline{390}$ \\
\hline Sep-00 & 54 & $3 \%$ & 115 & $7 \%$ & 28 & $2 \%$ & 1,608 \\
\hline Oct-00 & 72 & $4 \%$ & 98 & $6 \%$ & 28 & $2 \%$ & 1,713 \\
\hline Nov-00 & 63 & $3 \%$ & $\overline{185}$ & $10 \%$ & 32 & $2 \%$ & 1,847 \\
\hline Dec-00 & 59 & $4 \%$ & 270 & $16 \%$ & 27 & $2 \%$ & 1,640 \\
\hline Jan-01 & 79 & $4 \%$ & 315 & $14 \%$ & 72 & $3 \%$ & 2,251 \\
\hline Feb-01 & 74 & $3 \%$ & 258 & $12 \%$ & 84 & $4 \%$ & 2,188 \\
\hline Mar-01 & 82 & $4 \%$ & 276 & $12 \%$ & 59 & $3 \%$ & 2,210 \\
\hline Apr-01 & 81 & $4 \%$ & 138 & $7 \%$ & 127 & $6 \%$ & 2,034 \\
\hline May-01 & 96 & $5 \%$ & 133 & $6 \%$ & 122 & $6 \%$ & 2,094 \\
\hline Jun-01 & 143 & $3 \%$ & 101 & $2 \%$ & 46 & $1 \%$ & 4,694 \\
\hline Jul-01 & 114 & $6 \%$ & 91 & $5 \%$ & 80 & $4 \%$ & 1,985 \\
\hline Aug-01 & 162 & $6 \%$ & 42 & $2 \%$ & 85 & $3 \%$ & 2.786 \\
\hline Sep-01 & 127 & $7 \%$ & 44 & $3 \%$ & 57 & $3 \%$ & 1,728 \\
\hline Oct-01 & 126 & $6 \%$ & 80 & $4 \%$ & 65 & $3 \%$ & 2,058 \\
\hline Nov-01 & 116 & $5 \%$ & 138 & $6 \%$ & 111 & $5 \%$ & 2,172 \\
\hline Dec-01 & 107 & $6 \%$ & 106 & $6 \%$ & 141 & $8 \%$ & 1,873 \\
\hline Jan- 02 & 142 & $6 \%$ & 114 & $5 \%$ & 133 & $5 \%$ & 2,473 \\
\hline
\end{tabular}


TABLE 20: (CONTINUED)

\begin{tabular}{|c|c|c|c|c|c|c|c|}
\hline \multirow{2}{*}{ Month } & \multicolumn{2}{|c|}{$\begin{array}{l}\text { Single board member } \\
\text { decisions }\end{array}$} & \multicolumn{2}{|c|}{ Affirmances without opinion } & \multicolumn{2}{|c|}{ Summary dismissals } & \multirow{2}{*}{$\begin{array}{l}\begin{array}{l}\text { Total BIA } \\
\text { decisions }\end{array} \\
\text { Percent of total }\end{array}$} \\
\hline & $N$ & Percent of total & $N$ & Percent of total & $N$ & Percent of total & \\
\hline Feb-02 & 155 & $5 \%$ & 174 & $6 \%$ & 121 & $\overline{4 \%}$ & 3,018 \\
\hline Mar-02 & 183 & $4 \%$ & 311 & $6 \%$ & 1,634 & $32 \%$ & 5,112 \\
\hline Apr-02 & 261 & $4 \%$ & 1,102 & $18 \%$ & 1,192 & $20 \%$ & 5,967 \\
\hline May-02 & 285 & $7 \%$ & 1,136 & $26 \%$ & 136 & $3 \%$ & 4,328 \\
\hline Jun-02 & 385 & $8 \%$ & 1,390 & $28 \%$ & 109 & $2 \%$ & 4,878 \\
\hline Jul-02 & 404 & $8 \%$ & 1,471 & $30 \%$ & 85 & $2 \%$ & 4,840 \\
\hline Aug-02 & 356 & $9 \%$ & 1,420 & $36 \%$ & 79 & $2 \%$ & 3,968 \\
\hline Sep-02 & 446 & $10 \%$ & 1,681 & $39 \%$ & 67 & $2 \%$ & 4,362 \\
\hline Oct-02 & 586 & $12 \%$ & 2,007 & $41 \%$ & 65 & $1 \%$ & 4,933 \\
\hline Nov-02 & 475 & $12 \%$ & 1,459 & $37 \%$ & 56 & $1 \%$ & 3,932 \\
\hline Dec-02 & 779 & $14 \%$ & 1,795 & $33 \%$ & 97 & $2 \%$ & 5,501 \\
\hline Jan-03 & 918 & $20 \%$ & 1,327 & $29 \%$ & 32 & $1 \%$ & 4,568 \\
\hline Feb-03 & 619 & $18 \%$ & 977 & $28 \%$ & 61 & $2 \%$ & 3,461 \\
\hline Mar-03 & 545 & $16 \%$ & 873 & $25 \%$ & 72 & $2 \%$ & 3,512 \\
\hline Apr-03 & 547 & $17 \%$ & 664 & $21 \%$ & 72 & $2 \%$ & 3,228 \\
\hline May-03 & 933 & $29 \%$ & 573 & $18 \%$ & 97 & $3 \%$ & 3,244 \\
\hline Jun-03 & 1,058 & $31 \%$ & 641 & $19 \%$ & 69 & $2 \%$ & 3,409 \\
\hline Jul-03 & 795 & $23 \%$ & 678 & $20 \%$ & 86 & $3 \%$ & 3,385 \\
\hline Aug-03 & 653 & $19 \%$ & 790 & $23 \%$ & 98 & $3 \%$ & 3,454 \\
\hline
\end{tabular}

Source: EOIR response to the authors' FOIA request. See supra Part III.D. 